\title{
SISTEMA FUNCIONAL DE CONTROLE DE QUALIDADE A SER UTILIZADO COMO PADRÃO NA CADEIA DE COMERCIALIZAÇÃO DE LARANJA PÊRA Citrus sinensis L. Osbeck
}

\section{AMÁlia SOLANGE DE TOLEDO MENDES RAMALHO}

Dissertação apresentada à Escola Superior de Agricultura "Luiz de Queiroz”, Universidade de São Paulo, para obtenção do título de Mestre em Agronomia, Área de Concentração: Ciência e Tecnologia de Alimentos.

PIRACICABA

Estado de São Paulo - Brasil

Junho - 2005 


\title{
SISTEMA FUNCIONAL DE CONTROLE DE QUALIDADE A SER UTILIZADO COMO PADRÃO NA CADEIA DE COMERCIALIZAÇÃO DE LARANJA PÊRA Citrus sinensis L. Osbeck
}

\author{
AMÁlia SOLANGE DE TOLEDO MENDES RAMALHO \\ Engenheira Agrônoma
}

Orientadora: Prof. ${ }^{\mathrm{a}}$ Dr. ${ }^{\mathrm{a}}$ MARTA HELENA FILLET SPOTO

Dissertação apresentada à Escola Superior de Agricultura “Luiz de Queiroz”, Universidade de São Paulo, para obtenção do título de Mestre em Agronomia, Área de Concentração: Ciência e Tecnologia de Alimentos.

PIRACICABA

Estado de São Paulo - Brasil

Junho - 2005 
Dados Internacionais de Catalogação na Publicação (CIP) DIVISÃO DE BIBLIOTECA E DOCUMENTAÇÃO - ESALQ/USP

Ramalho, Amália Solange de Toledo Mendes

Sistema funcional de controle de qualidade a ser utilizado como padrão na cadeia de comercialização de laranja Pêra Citrus sinensis L. Osbeck / Amália Solange de Toledo Mendes Ramalho. - - Piracicaba, 2005.

91 p. : il.

Dissertação (mestrado) - - Escola Superior de Agricultura Luiz de Queiroz, 2005. Bibliografia.

1. Análise físico-química 2. Análise sensorial 3. Comercialização 4. Consumidor 5. Controle de qualidade 6. Laranja pêra 7. Normalização I. Título

CDD 634.31

"Permitida a cópia total ou parcial deste documento, desde que citada a fonte - $\mathrm{O}$ autor" 
DEDICATÓRIA

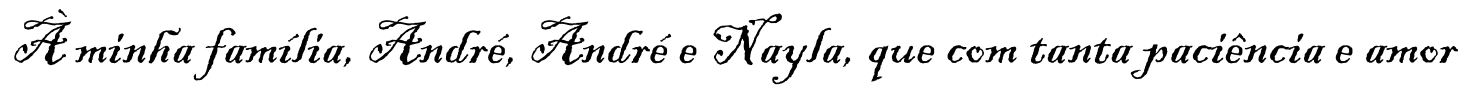
estão sempre presentes nos momentos importantes.

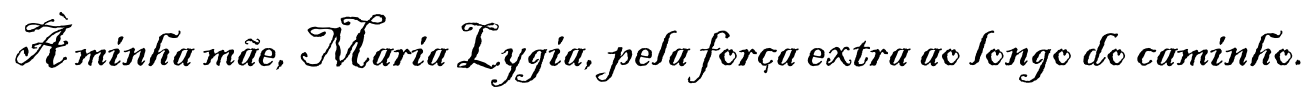

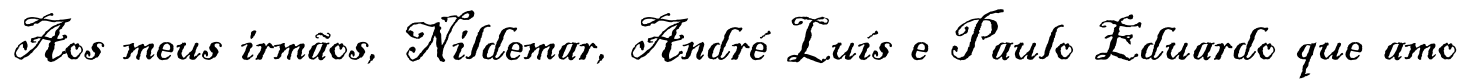
tanto.

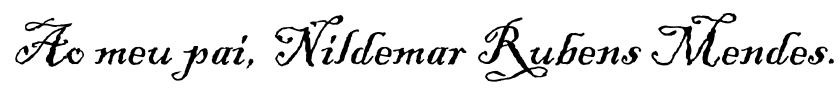

市s sincronicidades da vida. 


\section{AGRADECIMENTOS}

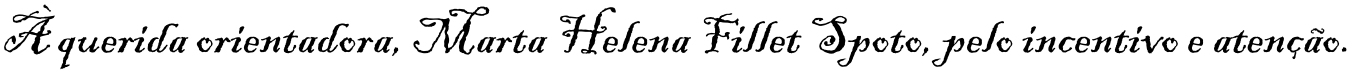

市 Mariana Kikuchi, no acompanhamento deste trabaJho, desde o início, colaforando sempre.

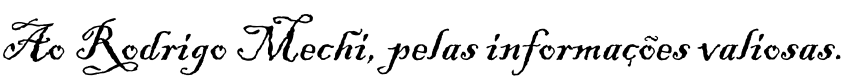

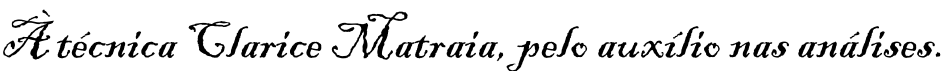

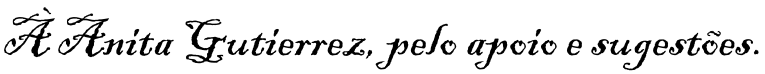

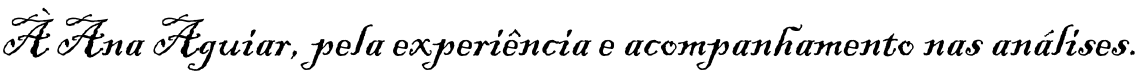

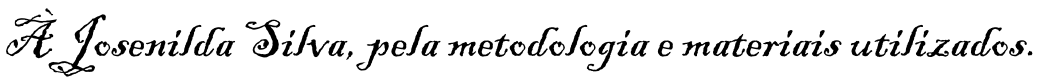

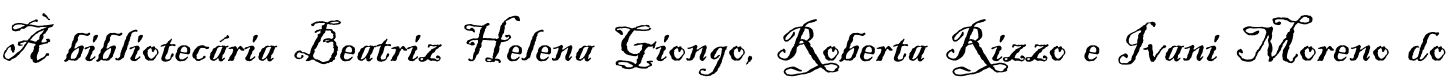

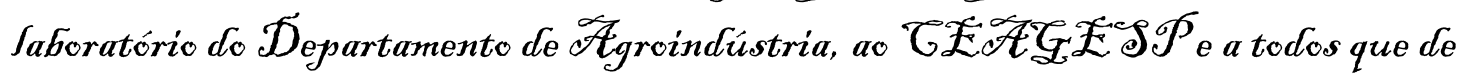
alguma forma contrifuíram para a reafização deste trabaҺho, agradeço de coraçũo.

"É ambição suficiente atuar como modesto obreiro na tarefa de fimpar um pouco o terreno e remover parte dos detritos que obstruem o caminho do confiecimento". Lohin Locke (1632-1704). 


\section{SUMÁRIO}

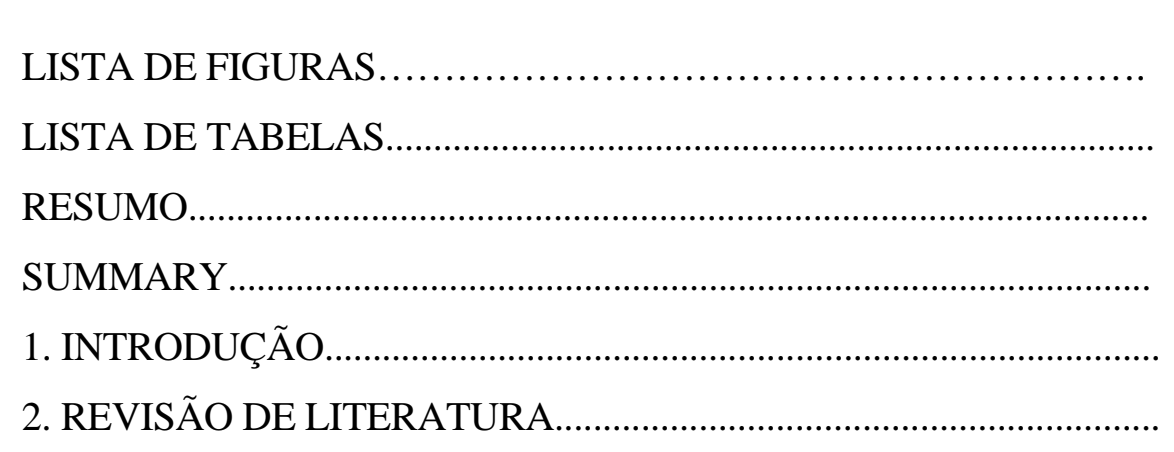

Página

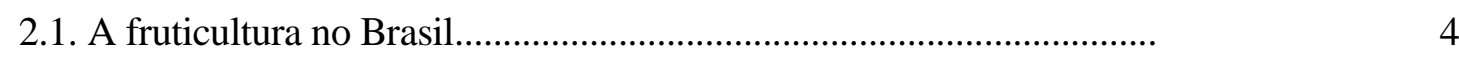

2.2. A laranja Pêra Citrus sinensis L. Osbeck.................................................

2.3. Padronização e Classificação da laranja Pêra .......................................

2.4. Qualidade da laranja..........................................................................

2.4.1. Aparência ..................................................................................... 15

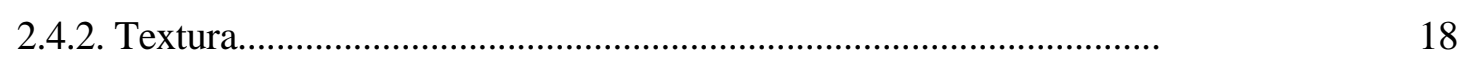

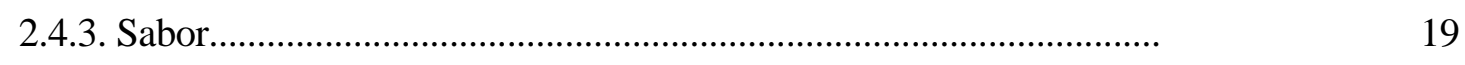

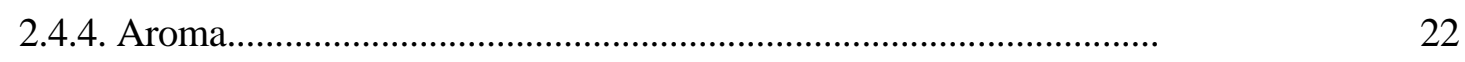

2.5. A origem dos frutos analisados............................................................ 23

2.6. Análise Descritiva Quantitativa............................................................ 23

2.7. QFD e o Planejamento da Qualidade................................................... 25

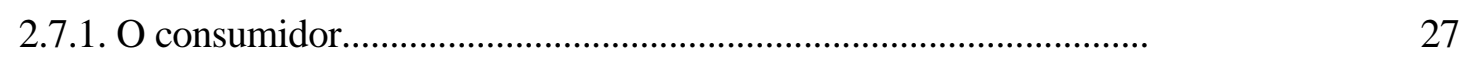

3. MATERIAL E MÉTODOS..................................................................... 29

3.1. As análises físico-químicas da laranja Pêra........................................ 29

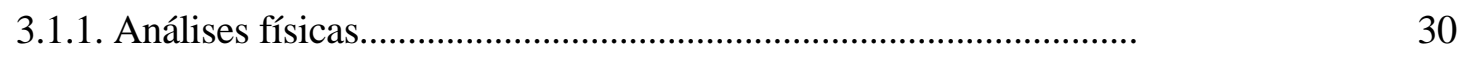

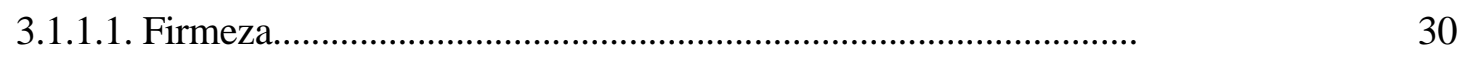

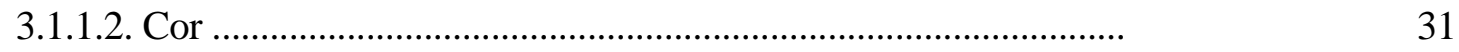




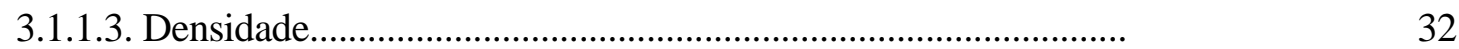

3.1.2. Análises químicas.............................................................................

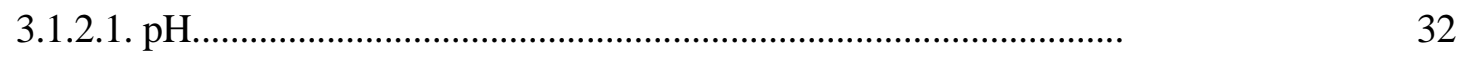

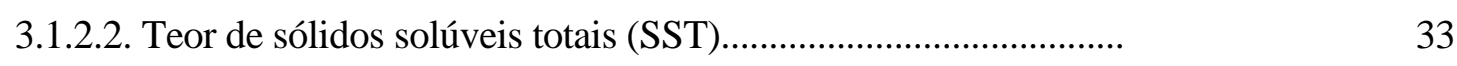

3.1.2.3. Acidez total titulável (ATT).......................................................... 33

3.1.2.4. Razão sólidos solúveis / acidez titulável (Ratio)........................... 33

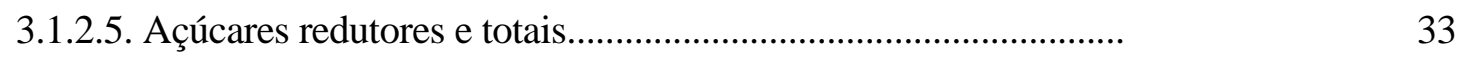

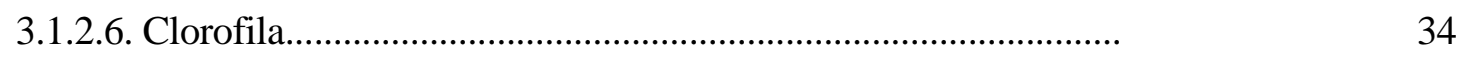

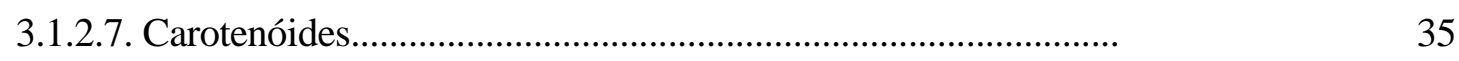

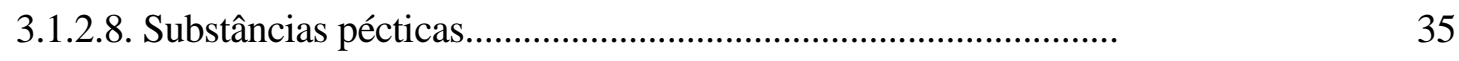

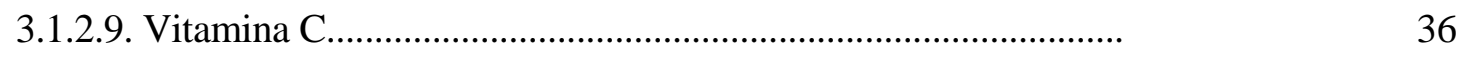

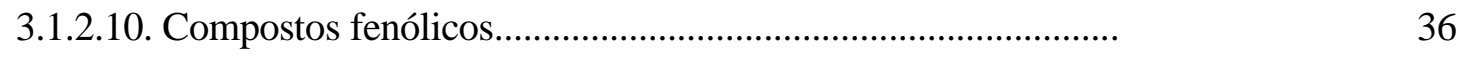

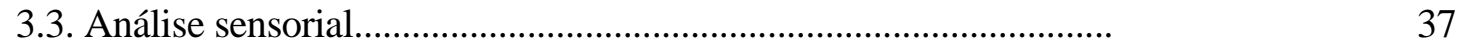

3.3.1. Treinamento e desenvolvimento da terminologia descritiva......... 40

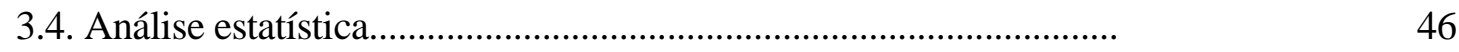

3.5. Identificação das necessidades dos clientes............................................ 46

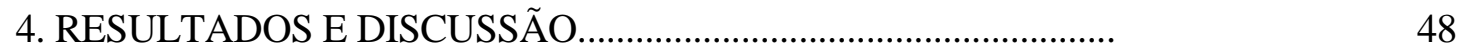

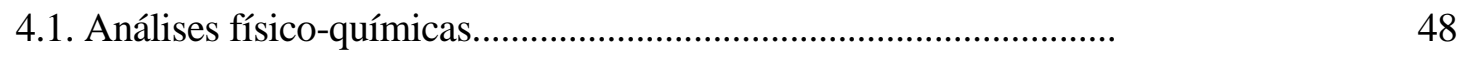

4.2. Análise sensorial.............................................................................

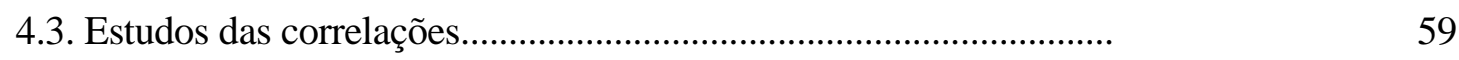

4.4. Resultados preliminares do método QFD com a identificação

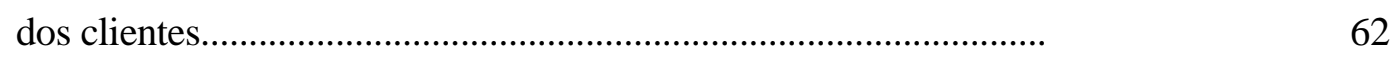

4.4.1. Mercado Municipal de Piracicaba (Mercadão)............................... 62

4.4.2. Supermercado Pão de Açúcar (Centro)........................................... 73

5. CONCLUSÕES.............................................................................

6. REFERÊNCIAS BIBLIOGRÁFICAS................................................ 


\section{LISTA DE FIGURAS}

Página

1 Programa brasileiro para a melhoria dos padrões comerciais

e embalagens de hortigranjeiros (CEAGESP, 2000).

2 Ficha da laranja Pêra para acompanhamento de produção e

qualidade da fruta em região de Barretos, SP.

3 Disco de cores.

$4 \quad$ Escala de cores com L Hunter Luminosidade, $a^{*}$ Hunter

(vermelho ao verde) e b* Hunter (amarelo ao azul)......................................... 4

$5 \quad$ Ficha de recrutamento de provadores.............................................................. 5

$6 \quad$ Modelo da ficha de reconhecimento de gostos básicos................................... 6

$7 \quad$ Modelo da ficha do teste de sensitividade para gosto........................................

8 Modelo da ficha de levantamento de atributos................................................. 8

$9 \quad$ Levantamento de Termos da Laranja Pêra (Limeira-Barretos)......................... 9

10 Ficha de Análise Descritiva Quantitativa de laranja Pêra

das regiões de Barretos e Limeira.

11 Definição dos descritores e referências dos extremos

das escalas de intensidade na ADQ de laranja Pêra.

12 Questionário utilizado para a realização da Avaliação

Qualitativa no Mercado Municipal de Piracicaba

(Mercadão) e no Supermercado Pão de Açúcar (Centro).

13 Percentual de variedades citadas pelos compradores

de laranja Pêra no (Mercado Municipal) Mercadão. 
14 Destino dado à laranja Pêra comprada no Mercado Municipal de Piracicaba.

15 Características observadas pelos entrevistados no Mercado Municipal de Piracicaba

16 Características esperadas pelos entrevistados no Mercado Municipal de Piracicaba.

17 Características da laranja Pêra ideal citadas pelos entrevistados no Mercado Municipal de Piracicaba...

18 Problemas encontrados na laranja Pêra pelos entrevistados no Mercado Municipal de Piracicaba

19 Percentual de entrevistados que pagariam mais pela laranja considerada ideal

20 Distribuição quanto ao sexo dos entrevistados no Mercado Municipal de Piracicaba

21 Distribuição quanto ao sexo dos entrevistados no Supermercado Pão de Açúcar..

22 Distribuição dos entrevistados no Mercado Municipal de Piracicaba quanto à paternidade.

23 Distribuição dos entrevistados no Mercado Municipal de Piracicaba quanto à escolaridade

24 Distribuição dos entrevistados no Mercado Municipal de Piracicaba quanto à idade.

25 Distribuição dos entrevistados no Mercado Municipal de Piracicaba em relação ao estado civil.

26 Distribuição em número de salários mínimos dos entrevistados no Mercado Municipal de Piracicaba.

27 Percentual de variedades citadas pelos entrevistados no Supermercado Pão de Açúcar.

28 Destino dado à laranja Pêra comprada no Supermercado Pão de Açúcar. 
29 Características observadas pelos entrevistados no Supermercado Pão de Açúcar..

30 Características esperadas pelos entrevistados no

31 Características da laranja Pêra ideal, citadas pelos entrevistados no Supermercado Pão de Açúcar..

32 Problemas encontrados na laranja Pêra pelos entrevistados no Supermercado Pão de Açúcar.

33 Percentual de compradores de laranja Pêra no Supermercado que pagariam a mais ou não por uma laranja considerada "ideal". 


\section{LISTA DE TABELAS}

1. Valores médios de peso, volume, densidade e diâmetro de laranjas com

Página coloração C1, C2 e C3 da região de Barretos e C2, C3 e C4 da região de Limeira

2. Valores médios de cor (L, a*, b*) e resistência de laranjas com coloração C1, C2 e C3 da região de Barretos e C2, C3 e C4 da região de Limeira.

3. Valores médios de teor de sólidos solúveis (TSS), ratio, pH, acidez e vitamina C de laranjas com coloração C1, C2 e C3 da região de Barretos e C2, C3 e C4 da região de Limeira

4. Valores médios de clorofila, carotenóides, açúcar total, açúcar redutor, compostos fenólicos e pectina total e solúvel de laranjas com coloração C1, C2 e C3 da região de Barretos e C2, C3 e C4 da região de Limeira. 56

5. Valores médios para atributos de aparência de laranjas com coloração C1, C2 e C3 da região de Barretos e C2, C3 e C4 da região de Limeira.

6. Valores médios para atributos de aroma de laranjas C1, C2 e C3 da região de Barretos e C2, C3 e C4 da região de Limeira.....

7. Valores médios para atributos de textura de laranjas com coloração C1, C2 e C3 da região de Barretos e C2, C3 e C4 da região de Limeira 
.8. Valores médios para atributos de sabor de laranjas com coloração

C1, C2 e C3 da região de Barretos e C2, C3 e C4 da região de Limeira................

9. Coeficientes de correlação $(>0,70)$ para os dados de análises

físico-químicas e sensoriais de laranja Pêra... 


\title{
SISTEMA FUNCIONAL DE CONTROLE DE QUALIDADE A SER UTILIZADO COMO PADRÃO NA CADEIA DE COMERCIALIZAÇÃO DE LARANJA PÊRA Citrus sinensis L. Osbeck
}

\author{
Autora: AMÁLIA SOLANGE DE TOLEDO MENDES RAMALHO \\ Orientadora: Prof. ${ }^{a}$ Dr. ${ }^{a}$ MARTA HELENA FILLET SPOTO
}

\section{RESUMO}

Os objetivos do presente trabalho visam correlacionar parâmetros sensoriais com físico-químicos, estabelecendo-se medidas exatas da qualidade da laranja Pêra para mesa; padronizar, utilizando métodos científicos para servir de base na construção de controle de qualidade mensurável de aplicação simples para o agricultor, visando à garantia da qualidade do produto, aumentando o seu valor e conseqüentemente a receita do produtor e a modernização do setor. Os frutos provenientes das regiões de Barretos e Limeira, foram trazidos ao Departamento de Agroindústria, Alimentos e Nutrição (ESALQ/USP) e ao CENA (USP), onde foram realizadas as análises físicas (firmeza, cor, densidade, diâmetro e comprimento), físico-químicas (pH, sólidos solúveis, acidez total titulável, ratio, açúcares redutores e totais, compostos fenólicos totais, substâncias pécticas, clorofila, carotenóides, vitamina C) e sensorial, segundo a metodologia da Análise Descritiva Quantitativa (AQD). Os parâmetros que melhor caracterizaram os estádios de maturação da laranja Pêra da região de Limeira foram pectina solúvel, 
carotenóides, $\mathrm{pH}$, cor (valor L, a* e b*), e os atributos sensoriais aparência: cor laranja, fruto murcho; aroma: doce, passado e ácido; sabor: maduro, ácido e doce. As laranjas provenientes de Barretos foram melhores caracterizadas pelos parâmetros: cor ( $\mathrm{L}, \mathrm{a}^{*}$ e b*), pH, TSS, ATT, Ratio, vitamina C, açúcar total e redutor e pectina solúvel e pelos atributos sensoriais de aparência: cor laranja, uniforme; aroma: ácido, doce; sabor: ácido, doce, passado. A coloração C3, para ambas as regiões (Limeira e Barretos), indica o melhor estádio de maturação para a laranja Pêra, apresentando as melhores características sensoriais. Pesquisas realizadas como o consumidor da laranja Pêra, revelam que nos dois locais comerciais da cidade de Piracicaba, a maioria era do sexo feminino, apreciavam mais a firmeza do fruto, cor, suculência, sabor doce e baixa acidez. Todos pagariam a mais pela laranja Pêra considerada ideal. 


\title{
FUNCTIONAL QUALITY CONTROL SYSTEM TO BE USED AS A MARKETING STANDARD FOR THE PRODUCTION OF FRESH- FRUIT PÊRA ORANGE Citrus sinensis L. Osbeck
}

\author{
Author: AMÁLIA SOLANGE DE TOLEDO MENDES RAMALHO
}

Adviser: Prof. ${ }^{a}$ Dr. ${ }^{a}$ MARTA HELENA FILLET SPOTO

\section{SUMMARY}

The objectives of this study were 1) to correlate the visual parameters with the physical-chemical parameters to establish exact measurements for the quality of fresh fruit oranges (cultivar Pêra), and 2) to establish standards by utilizing scientific methods to serve as a basis for quality control measurements that can be simply applied by the farmers with the purpose of assuring product quality, thus increasing the value of the oranges, the revenue of the farmers and improving the sector. Orange fruits were obtained from the regions of Barretos and Limeira, SP, Brazil, and analyzed in the Agro industry, Food and Nutrition Department of ESALQ/USP and at CENA/USP. Physical aspects of the fruits (firmness, color, density, diameter and length), physical-chemical properties $\mathrm{pH}$, soluble solids (SST), titrateable total acidity (ATT), ratio, total and reducing sugars, total phenolic compounds, pectic substances, chlorophyll, carotenoids, and vitamin C) and visual traits according to the Descriptive Quantitative Analysis Index (DQA) were analyzed. 
Parameters that best characterized the ripening stage of Pêra oranges from Limeira were soluble pectin, carotenoids, $\mathrm{pH}$, color (value $\mathrm{L}, \mathrm{a}^{*}$ and $\mathrm{b}^{*}$ ), and the visual attributes appearance: orange color and soft fruit, aroma: sweetness, over ripening and acidity, and flavor: ripen, acidity and sweetness. Fruits from Barretos were best characterized by the parameters color ( $\mathrm{L}, \mathrm{a}^{*}$ and $\mathrm{b}^{*}$ ), $\mathrm{pH}$, TSS, ATT, ratio, vitamin C, total and reducing sugars, soluble pectin and the visual attributes appearance: orange color and uniformity, aroma: acidity and sweetness, and flavor: acidity, sweetness and over ripening. The coloration C3 for fruits from both regions indicated the best maturation stage for Pêra oranges and was associated with the best visual characteristics. Studies were conducted with consumers, mainly female, of Pêra oranges. At two commercial sites in Piracicaba, these studies showed that they preferred the fruit attributes firmness, color, juiciness, sweet flavor and low acidity, and they would pay more for oranges that had these ideal qualities. 


\section{INTRODUÇÃO}

O Brasil, com seu grande território caracterizado pelas nuances de clima e solos variados, apresenta também grande produção agrícola diversificando-se nos vários setores do mercado. O Programa de Estudos dos Negócios do Sistema Agroindustrial da Universidade de São Paulo (Fundo de Defesa da Citricultura-FUNDECITRUS, 2004) revela que, em 2003, o setor citrícola movimentou US\$ 3,23 bilhões, número que não contabiliza o atacado e o varejo. A participação do Brasil no comércio mundial de suco de laranja é significativa, enquanto que, da fruta in natura é marginal. O Brasil representa $80 \%$ do comércio mundial de suco de laranja (1.348.200 toneladas de suco concentrado), em contraposição ao da fruta in natura (0,7\% correspondente a 139.600 toneladas). A Espanha e os Estados Unidos se destacam como exportadores de laranja in natura, com $38 \%$ e $18 \%$, respectivamente.

Em São Paulo, as principais regiões de produção de laranja estão concentradas em poucos municípios. As regiões de Barretos, São José do Rio Preto, Catanduva, Jaboticabal, Araraquara, São João da Boa Vista, Mogi Mirim e Limeira são responsáveis por $84 \%$ da área total de laranja no estado. Nas cinco primeiras regiões está instalada a maioria das indústrias de suco concentrado. Essas regiões destinam sua produção tanto para a indústria como para o mercado in natura. As regiões de Limeira e Mogi Mirim são tradicionais na comercialização de frutas para o mercado interno, em função das poucas indústrias instaladas nessa região. Elas abastecem São Paulo e outros estados, principalmente da Região Sul (Centro de Estudos Avançados em Economia AplicadaCEPEA, 2004).

O renascimento da citricultura paulista no século 20 ocorreu devido ao fortalecimento da indústria de suco concentrado congelado. Esta nasceu e consolidou-se absorvendo a maior parte da produção de laranjas, traçando metas e norteando os rumos 
quanto às regiões citrícolas e variedades para o plantio. Laranjas de reconhecidas qualidades para a mesa, como a Bahia, Baianinha e Barão deixaram de ter o destaque que possuíam no cenário citrícola. O consumo interno cresceu atrelado às variedades demandadas pelas indústrias de suco. $\mathrm{Na}$ virada do século, constata-se certo revigoramento no interesse pelas frutas de consumo ao natural, especialmente para pomares mais bem localizados quanto às condições climáticas e mercado consumidor. As perspectivas são animadoras e todo o mercado interno precisa ser replanejado para atingir as metas ambicionadas.

A exportação de frutas in natura enfrenta a acirrada competição dos produtores do hemisfério sul e não apresenta um caminho dos mais atraentes para o escoamento da safra nacional. O país exporta menos de $1 \%$ de sua produção citrícola atual. O consumo interno, propiciado por 160 milhões de habitantes (33 milhões apenas no Estado de São Paulo), faz antever um mercado mais promissor e com potencial de crescimento bastante atrativo. A fruta fresca é dependente da qualidade, o que de certa maneira não tem sido observada pela maioria dos produtores e mercadistas. Citricultores, comerciantes e agências governamentais precisam repensar o mercado interno de frutas cítricas. Valores esquecidos no passado precisarão ser renovados.

O mercado externo sempre se portou de modo exigente em termos de qualidade, que é fundamental para frutas de mesa, estabelecendo inúmeros critérios para efeito de exportação; entretanto, atualmente os consumidores do mercado interno também estão fazendo valer os seus direitos na aquisição de bons produtos em sua mesa. Qualidade é tamanho, cor, espessura de casca, paladar do suco, ratio, teor de suco, etc.

O entendimento do processo de valorização do produto e a mensuração de suas características são essenciais ao aumento da receita do produtor e alavancagem da modernização do setor.

Os objetivos deste trabalho visam atingir o produtor, o mercado, o consumidor e toda a cadeia produtiva da laranja consumida in natura, que permitam a escolha do melhor ponto de colheita, melhor colocação do produto no embalador, no atacado e no varejo; produto mais saboroso e de características organolépticas constantes, através de correlação de medidas sensoriais com medidas físico-químicas, e com isso, estabelecer 
os parâmetros exatos da qualidade do fruto a ser colhido; padronizando as características do produto, podendo resultar em maior transparência na comercialização e diminuição dos atritos comerciais.

A comercialização desses frutos se resume no conjunto de operações ou funções realizadas no processo de levar bens e serviços desde o produtor primário até o consumidor final. Tem como objetivo a satisfação dos desejos e das necessidades dos consumidores. Entretanto, do ponto de vista das empresas, uma das funções da comercialização é ampliar ou mesmo modificar a demanda do consumidor através da técnica promocional (Hoffman\& Engler, 1978).

Nesse sentido, foi necessário ouvir as opiniões e necessidades dos clientes a respeito da laranja consumida in natura e a partir do levantamento dessas informações, determinarem as características desejadas para a fruta.

Utilizou-se o método QFD (Quality Function Deployment), Desdobramento da Função Qualidade, para se obter o levantamento das informações a respeito da qualidade da laranja. A elevada participação dos supermercados na compra mensal dos brasileiros e o variado grau de qualidade das frutas a que os consumidores ficam expostos, determinaram a escolha dos locais para o desenvolvimento deste tipo de trabalho. Os resultados de pesquisas obtidos sugerem informações valiosas que demonstram as necessidades e desejos dos consumidores de laranja Pêra nas bancas dos dois estabelecimentos comerciais em que se realizaram os levantamentos dos dados. 


\section{REVISÃO DE LITERATURA}

\subsection{A fruticultura no Brasil}

O Brasil, com seu grande território caracterizado pelas nuances de clima e solos variados, apresenta também grande produção agrícola diversificando-se nos vários setores do mercado.

A fruticultura representa cerca de 5\% das áreas cultivadas do país e o coloca em terceiro lugar no ranking mundial de frutas (Brasil, 2001).

A fruticultura brasileira, com 2 milhões de hectares cultivados, permite colher 32 milhões de toneladas de frutas cítricas e tropicais, onde quase 20 milhões de toneladas correspondem à laranja (Souza, 2001).

Apesar de sua indiscutível potência em termos de fertilidade do solo, elevados índices de insolação e abundância de água, o Brasil, na classificação mundial de exportação de frutas, com volume anual de 500.000 toneladas, o que representa US\$ 369.182.000, ainda é colocado no grupo de “outros exportadores”. Mas, as perspectivas de um aumento nas exportações são as mais promissoras, pois o produtor brasileiro está se conscientizando de que a qualidade das frutas é um fator de importância vital para o sucesso de sua produção e, conseqüentemente, de suas exportações. Pode-se identificar um grupo de frutas tradicionais, como banana, laranja e abacaxi, as quais detêm o nível do mercado externo, e também, outro grupo, o que poderia chamar de frutas dinâmicas, como manga, goiaba, maçã, mamão, melão e uva, as quais apresentaram crescimento acelerado nos últimos anos (Brasil, 2001).

Os produtos que mais se destacaram foram a laranja de mesa com 139,6 mil toneladas exportadas em 2001, contra 75,3 mil em 2000 (Globo Rural, 2004). 
Segundo o artigo encontrado no Jornal “O Estado de São Paulo”, Origem da laranja..., 2004, o Brasil é o maior produtor de laranjas do mundo com uma área cultivada de 820 mil hectares sendo 77\% referente à região sudeste.

O Brasil possui uma das maiores variedades de citros (laranjas, tangerinas e limões), representados por 210 milhões de árvores localizadas em São Paulo e Triângulo Mineiro, sendo a principal fonte econômica de 330 municípios, respondendo a 420 mil empregos diretos, movimentando US\$ 7 bilhões anualmente e gerando US\$ 1,2 bilhão ao ano em exportações (Souza, 2001).

\subsection{A laranja Pêra Citrus sinensis L. Osbeck}

As plantas cítricas (laranjeiras, limoeiros, tangerineiras, pomeleiros, cidreiras, toranjeiras, etc.) são originárias das regiões úmidas tropicais e subtropicais do continente asiático e ilhas adjacentes. Na Europa, a cor dourada do fruto permitiu à laranja ser associada à nobreza, onde os monarcas construíam nos jardins dos palácios as famosas orangeries, espaços onde esses frutos eram consumidos (Associação Brasileira dos Exportadores de Cítricos-ABECITRUS, 2003).

No Brasil as frutas cítricas foram, sem dúvida, introduzidas pelas primeiras expedições colonizadoras, provavelmente na Bahia, quando o país foi dividido pela Coroa Portuguesa em capitanias hereditárias, que trouxeram novos imigrantes; tanto assim que, em 1540, já existiam laranjais espalhados por todo litoral brasileiro, de norte a sul que aparecem retratados em diários ou pinturas de viajantes estrangeiros e após esse período quando a corte de D. João VI desembarcou no Brasil. Em 1800, com o surgimento da laranja-da-baía, o fruto ganhou uma versão bem brasileira e em 1973 foram levadas mudas por diplomatas americanos aos técnicos em citricultura na Califórnia, que deram origem aos seus laranjais com o nome de Washington Navel (ABECITRUS, 2003).

A laranja Pêra, Citrus sinensis L. Osbeck, pertence à família Rutaceae, subtribo Citrinae. Três gêneros têm importância econômica: Citrus, Fortunella e Poncirus. 
Caracteriza-se como árvore de porte médio, galhos mais ou menos eretos, folhas acuminadas. Sua produção atinge em média $250 \mathrm{~kg}$ de frutos por planta. Os frutos têm forma ovalada, com três a quatro sementes e peso médio de 145 g; a casca é de cor alaranjada, de espessura fina a média, quase lisa e com vesículas de óleo em nível. Tem polpa de cor laranja viva e textura firme, com suco abundante (Simão, 1971).

O destino do fruto é para consumo ao natural, nos mercados internos ou externos, ou para suco concentrado. É a variedade mais plantada no Estado de São Paulo, participando em número de plantas, com 52\% do total relativo a laranjas, onde se adapta muito bem (Oliva, 2002).

A composição da laranja varia conforme a variedade, cavalo, clima, altitude, adubação, tratos culturais e estágios de maturação. O fruto possui 50 a 55\% de suco, albedo 40 a $50 \%$ de flavedo, 5 a $10 \%$ de polpa e 4 sementes em média. A sua composição química é bastante complexa, apresentando os principais componentes: água, 86 a 92\%; açúcares, 5 a 8\%; pectina, 1 a 2\%; componentes nitrogenados, 0,7 a 0,8\%; lipídeos, 0,2 a 0,5\%; óleo essencial, 0,2 a $0,5 \%$; minerais 0,5 a $0,9 \%$ e outros componentes como: enzimas, pigmentos, constituintes voláteis, flavonóides e vitaminas (Viégas, 1991).

O desenvolvimento dos frutos se caracteriza por três fases distintas: a prématuração que inclui a metade do período entre floração e colheita, um aumento grande no volume, mas o fruto não apresenta qualidade ótima para o consumo e sim aceitável; maturação, onde o fruto atinge o crescimento pleno e máxima qualidade comestível e as principais mudanças que ocorrem são o desenvolvimento das sementes, mudanças na cor, na permeabilidade dos tecidos, textura, carboidratos, ácidos orgânicos, proteínas, compostos fenólicos, pigmentos, pectinas, etc. Porém, a etapa seguinte que corresponde ao amadurecimento, caracteriza um fruto mais palatável, completamente maduro onde sabores e odores específicos se desenvolvem juntos, com o aumento da doçura e acidez. Nesse estágio, ocorre seu amaciamento, mudança na coloração onde a clorofila decresce nos cloroplastos e os pigmentos carotenóides se desenvolvem. As mudanças do sabor, odor, cor e textura tornam o fruto aceitável para o consumo correspondendo às mudanças dos fatores sensoriais. A partir disso, segue-se o envelhecimento e morte de 
tecidos. As diferentes modificações que ocorrem durante o processo de amadurecimento sincronizam-se provavelmente com a sua genética, pois o intervalo entre a antese (abertura da flor) e amadurecimento, em condições climáticas similares, é relativamente constante para um determinado fruto (Ryall \& Lipton, 1979, citado em Chitarra, 1990).

Para a laranja, a maturação do fruto está ligada às condições climáticas e às variedades. Nas variedades precoces, os frutos amadurecem entre sete e oito meses, nas variedades tardias, de doze a quatorze meses (Simão, 1971).

\subsection{Padronização e Classificação da laranja Pêra}

No Brasil, as normas e padrões para a exportação de produtos de origem vegetal, são elaborados pelo Departamento Nacional de Serviços da Comercialização, Divisão de Inspeção, Padronização e Classificação (Brasil, 2000).

Alguns produtos destinados ao mercado interno são submetidos aos padrões de identidade e qualidade estabelecidos pelos órgãos competentes do Ministério da Agricultura, mas a maioria é selecionada regionalmente, em função da abundância ou escassez do produto. Portanto, há necessidade de programa para a elaboração de padrões, bem como o treinamento de equipes e informação ao produtor e comerciante para a melhor comercialização.

Classificação é a separação do produto por uma série de atributos: tamanho, peso, turgidez, coloração, grau de maturação e outros. A classificação desenvolvida pelo Centro de Qualidade em Horticultura (CQH) da Companhia de Entrepostos e Armazéns Gerais de São Paulo (CEAGESP), uniformiza a linguagem do mercado, fazendo com que produtores, atacadistas, indústrias, varejistas e consumidores utilizem os mesmos padrões para a determinação da qualidade do produto. Só assim, se obtêm transparência na comercialização, melhor preço para produtores e consumidores, menores perdas e melhor qualidade (CEAGESP, 2000). A classificação permite a valoração do produto, levando-se em conta as características físicas aparentes da fruta para identificar a qualidade frente ao consumidor. 
A Figura 1 apresenta o padrão do Programa brasileiro para a melhoria dos padrões comerciais e embalagens de hortigranjeiros (CEAGESP, 2000).

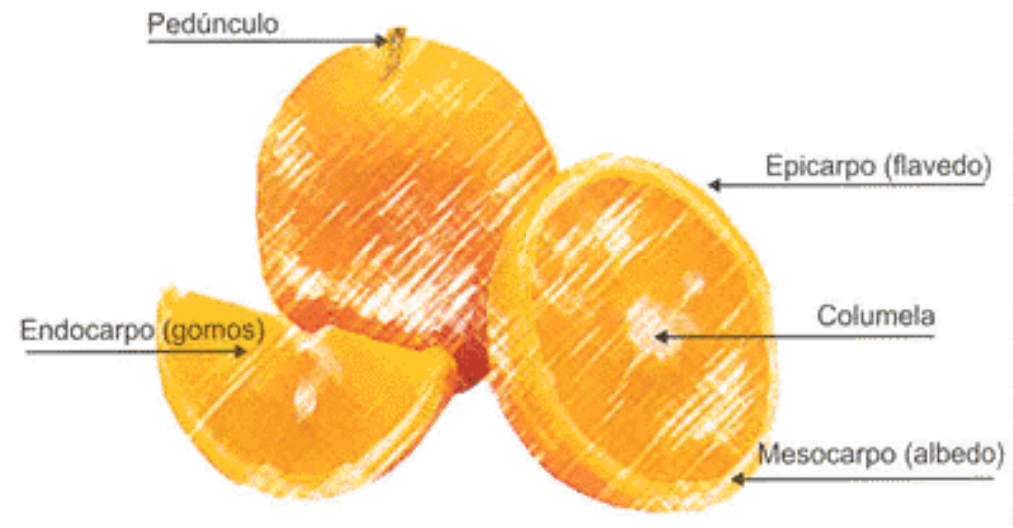

VARIEDADES MAIS COMUNS

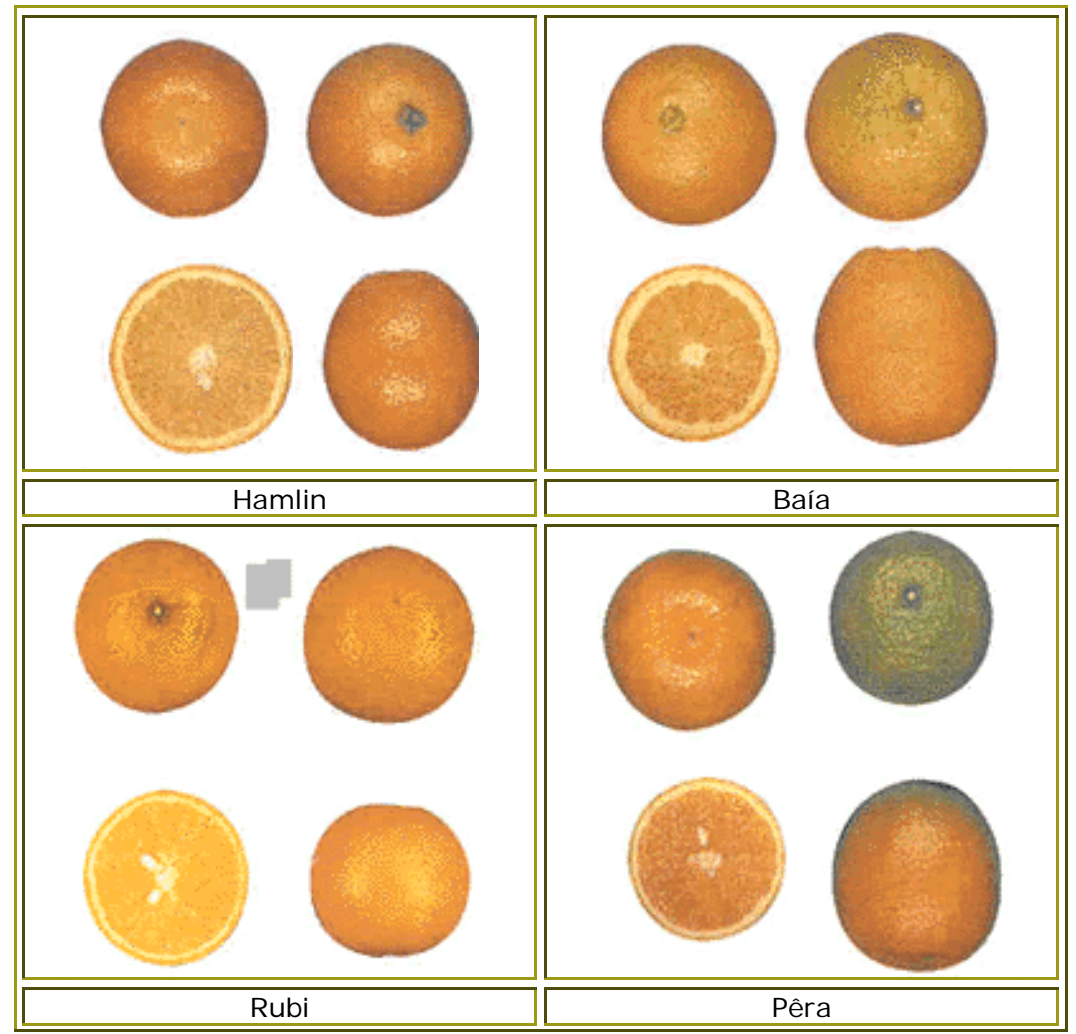




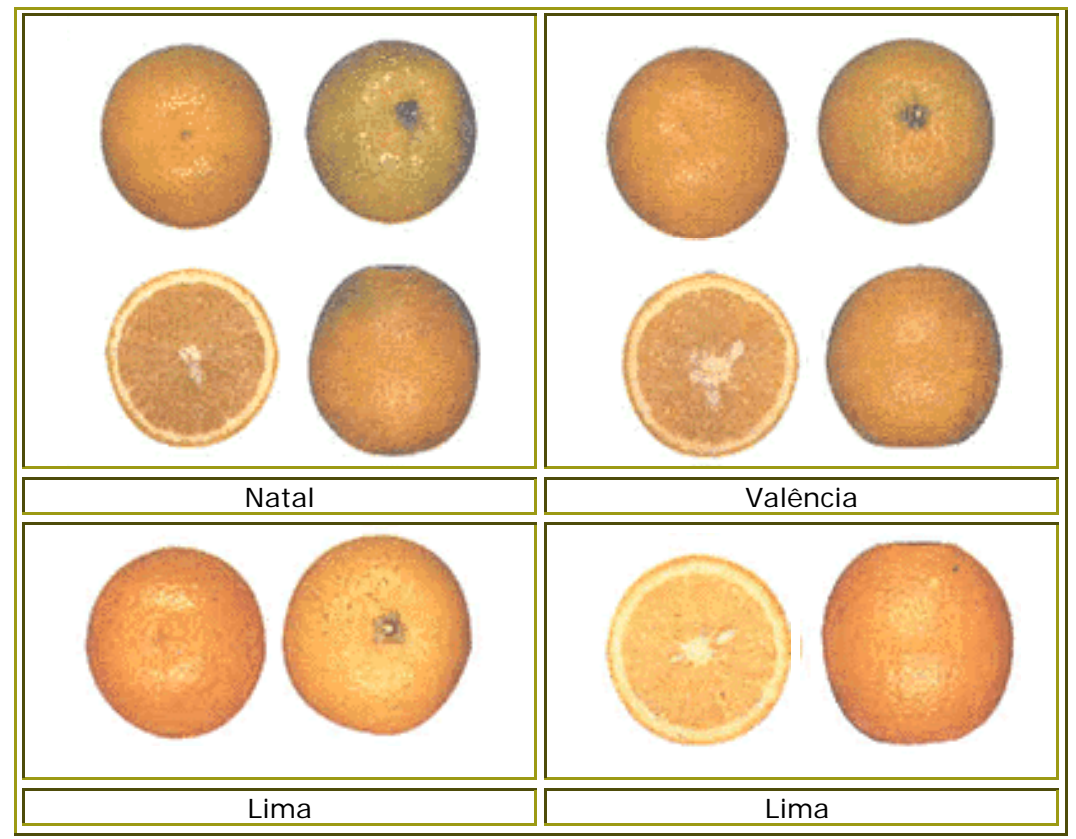

CLASSI FI CAÇÃO

Classificação é a separação do produto por cor, tamanho, formato e qualidade. Utilizar a classificação da laranja é unificar a linguagem do mercado, ou seja, produtores, atacadistas, varejistas e consumidores devem ter os mesmos padrões para determinar a qualidade do produto. Somente assim se obtêm transparência na comercialização, melhores preços para produtores e consumidores, menores perdas e maior qualidade.

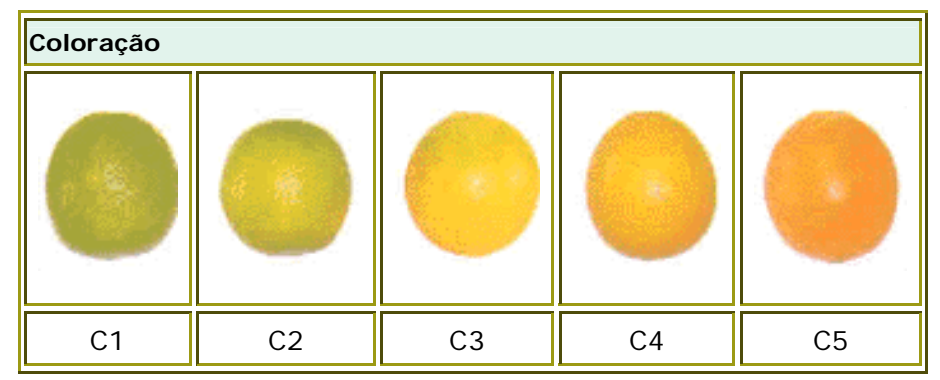

Figura 1. Programa brasileiro para a melhoria dos padrões comerciais e embalagens de hortigranjeiros (CEAGESP, 2000) 
Classe - Relacionada ao tamanho dos frutos medido pelo seu diâmetro equatorial, que é aquele medido transversalmente ao eixo que vai do pedúnculo ao ápice, conforme a tabela abaixo:

\begin{tabular}{|l|c|c||}
\hline Classe & Menor Diâmetro( $\mathbf{m m})$ & Maior Diâmetro( mm) \\
\hline $\mathbf{1 0 6}$ & 106 & 116 \\
\hline $\mathbf{9 8}$ & 98 & 106 \\
\hline $\mathbf{9 3}$ & 93 & 98 \\
\hline $\mathbf{8 9}$ & 89 & 93 \\
\hline $\mathbf{8 5}$ & 85 & 89 \\
\hline \hline $\mathbf{8 1}$ & 81 & 85 \\
\hline $\mathbf{7 8}$ & 78 & 81 \\
\hline $\mathbf{7 5}$ & 75 & 78 \\
\hline \hline $\mathbf{7 2}$ & 72 & 75 \\
\hline $\mathbf{6 8}$ & 68 & 72 \\
\hline \hline $\mathbf{6 6}$ & 66 & 68 \\
\hline \hline $\mathbf{6 3}$ & 63 & 66 \\
\hline $\mathbf{6 0}$ & 60 & 63 \\
\hline \hline $\mathbf{5 7}$ & 57 & 60 \\
\hline \hline $\mathbf{5 4}$ & 54 & 57 \\
\hline \hline
\end{tabular}

Tipo ou Categoria - É determinado pela ocorrência de defeitos graves e leves associados a requisitos de homogeneidade e presença de cálices nos frutos.

\begin{tabular}{|c|c|c|c|c|c|}
\hline Categoria & Extra & Cat I & Cat II & Cat III & Cat IV \\
\hline $\begin{array}{l}\text { Defeitos Graves } \\
\text { Podridão } \\
\text { Dano Profundo } \\
\text { Passado }\end{array}$ & $\begin{array}{l}0 \% \\
0 \% \\
0 \%\end{array}$ & $\begin{array}{l}2 \% \\
3 \% \\
1 \%\end{array}$ & $\begin{array}{l}3 \% \\
5 \% \\
3 \%\end{array}$ & $\begin{array}{l}4 \% \\
5 \% \\
9 \%\end{array}$ & $\begin{array}{l}4 \% \\
5 \% \\
9 \%\end{array}$ \\
\hline Total de Defeitos Graves & $0 \%$ & $3 \%$ & $5 \%$ & $9 \%$ & $9 \%$ \\
\hline Deformação & $0 \%$ & $1 \%$ & $10 \%$ & $20 \%$ & $100 \%$ \\
\hline $\begin{array}{l}\text { Mancha } \\
\text { Difusa Nível } 1 \\
\text { Difusa Nível } 2 \\
\text { Profunda Nível } 1 \\
\text { Profunda Nível } 2\end{array}$ & $\begin{array}{l}5 \% \\
0 \% \\
0 \% \\
0 \%\end{array}$ & $\begin{array}{c}20 \% \\
5 \% \\
15 \% \\
3 \% \\
\end{array}$ & $\begin{array}{l}40 \% \\
20 \% \\
20 \% \\
10 \% \\
\end{array}$ & $\begin{array}{l}100 \% \\
50 \% \\
30 \% \\
20 \%\end{array}$ & $\begin{array}{l}100 \% \\
100 \% \\
100 \% \\
100 \%\end{array}$ \\
\hline Total para manchas & $5 \%$ & $25 \%$ & $40 \%$ & $100 \%$ & $100 \%$ \\
\hline Total Geral & $5 \%$ & $25 \%$ & $40 \%$ & $100 \%$ & $100 \%$ \\
\hline
\end{tabular}

Figura 1. Programa brasileiro para a melhoria dos padrões comerciais e embalagens de hortigranjeiros (CEAGESP, 2000) 


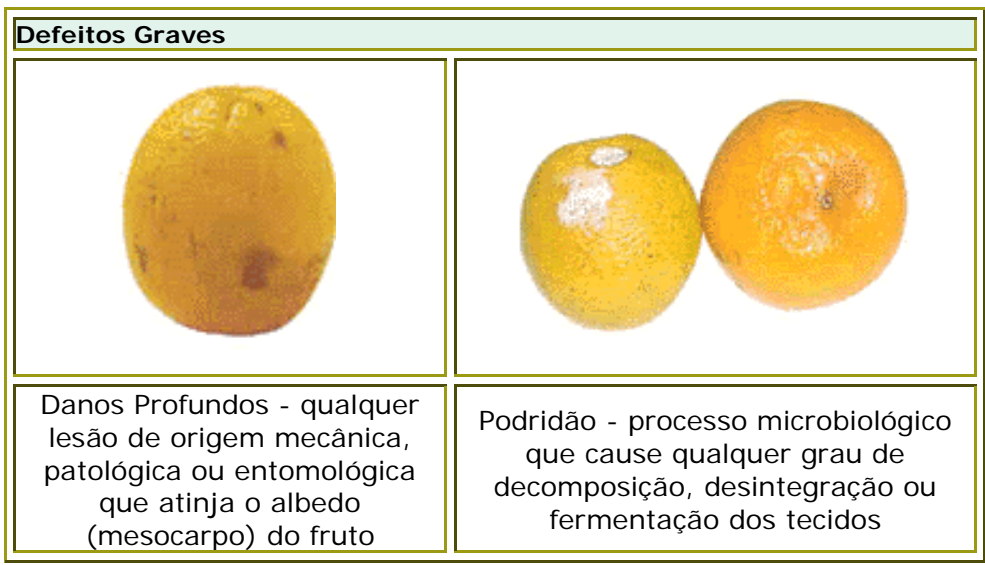

\section{Defeitos Leves}

Deformado - fruto com qualquer desvio da forma característica da cultivar. incluem-se as deformações de ordem fisiológica, de origem mecânica (amassamento) e a falta de turgescência causada pela desidratação

Manchas - São consideradas manchas, qualquer alteração da coloração da casca (pericarpo), não importando a origem desta alteração. Dividem-se em dois grupos:

Manchas difusas - conjunto de pequenas manchas que não encobrem a cor original da casca da laranja, permitindo a sua perfeita visualização.

Manchas profundas - são aquelas manchas que não permitem a visualização da cor original da casca do fruto, não importando a sua origem. Incluem-se aí os danos cicatrizados, as lesões patológicas, entomológicas e de ácaros que não atingiram o albedo.

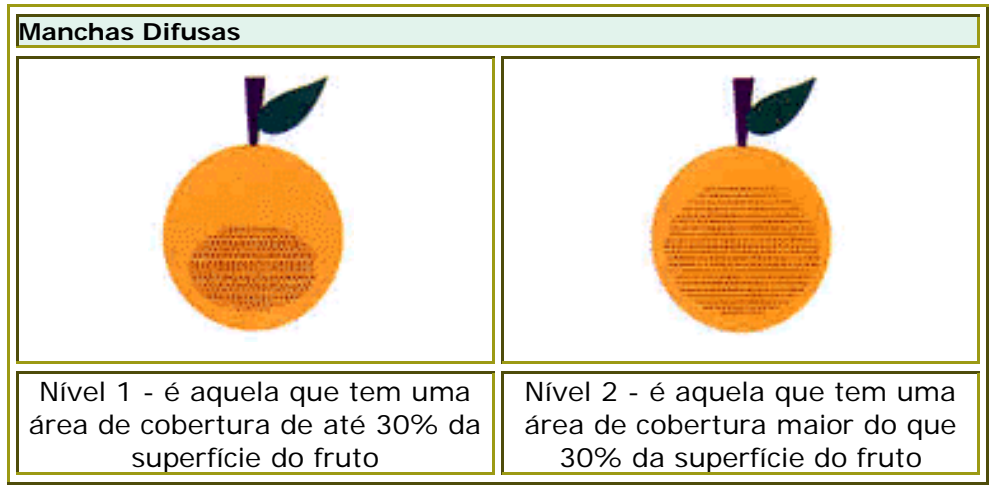

Figura 1. Programa brasileiro para a melhoria dos padrões comerciais e embalagens de hortigranjeiros (CEAGESP, 2000) 


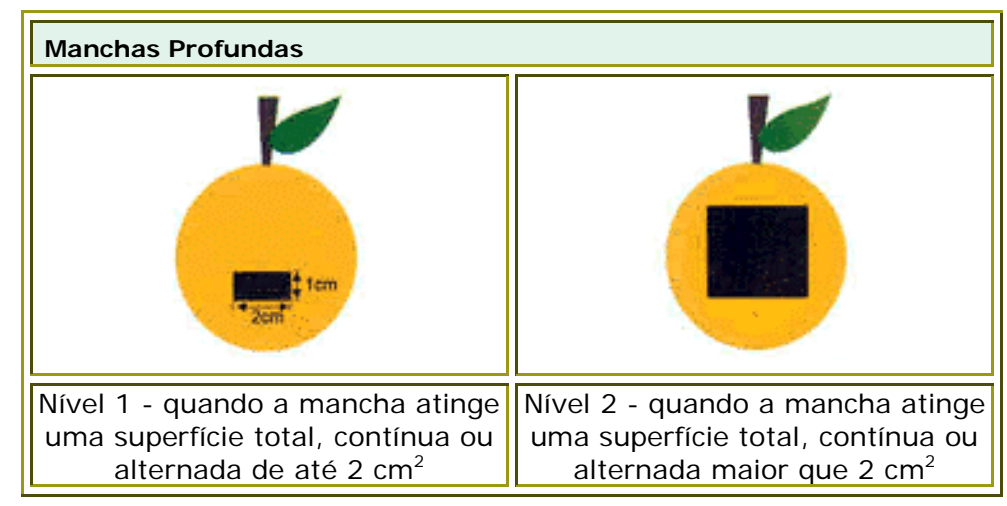

\begin{tabular}{|l|c|c|c|c|c||}
\hline \multicolumn{2}{|l|}{ Outros Requisitos } \\
\hline $\begin{array}{l}\% \text { Máxima de frutos sem } \\
\text { cálice }\end{array}$ & $5 \%$ & $20 \%$ & $35 \%$ & $100 \%$ & $100 \%$ \\
\hline $\begin{array}{l}\text { No de Classes } \\
\text { consecutivas no mesmo } \\
\text { lote }\end{array}$ & 1 & 2 & 3 & 5 & $\begin{array}{c}\text { sem } \\
\text { exigência }\end{array}$ \\
\hline $\begin{array}{l}\text { NNo de Grupos de } \\
\text { Coloração consecutivos } \\
\text { no mesmo lote }\end{array}$ & 1 & 2 & 3 & $\begin{array}{c}\text { sem } \\
\text { exigência }\end{array}$ & $\begin{array}{c}\text { sem } \\
\text { exigência }\end{array}$ \\
\hline
\end{tabular}

\section{REQUISITOS GERAIS}

1. As laranjas deverão apresentar as características típicas da cultivar quanto à forma, cor da casca, cor da polpa, levando-se em conta a região de produção.

2. Não será permitida dentro do programa a venda de laranja imatura. Entenda como imatura aquela que não atingiu o teor de sólidos solúveis (Brix), o Ratio (Açúcares/Acidez) e a Porcentagem de Suco (peso do suco/peso do fruto) x 100) considerados aceitáveis para consumo.

3. Os valores para cada variedade seguem a tabela abaixo. Os lotes que apresentarem teores superiores deverão mencioná-los como diferencial na rotulagem.

\begin{tabular}{|l|c|c|c||}
\hline Variedades & \% de Suco & Brix & Ratio \\
\hline Hamlin & 35 & 10,0 & 9,5 \\
\hline Baía & 35 & 10,0 & 9,5 \\
\hline \hline Rubi & 40 & 9,0 & 9,5 \\
\hline \hline Pêra & 45 & 10,0 & 9,5 \\
\hline \hline Natal & 44 & 10,0 & 9,5 \\
\hline Valência & 44 & 10,0 & 9,5 \\
\hline *Lima & 35 & 10,0 & \\
\hline
\end{tabular}

Valores determinados para São Paulo e Triângulo Mineiro

* Considerar apenas a \% de suco. 
4. Não será permitida a mistura de diferentes variedades dentro da mesma embalagem.

5.Admite-se até $5 \%$ de frutos fora do agrupamento das Classes citadas no rótulo.

6.Admite-se até $10 \%$ dos frutos fora dos grupos de coloração citados no rótulo. no lote.

7.0 rótulo deve indicar todos os grupos de coloração abrangidos

8. No caso da categoria III e IV, o comprador poderá exigir do vendedor do lote a discriminação dos defeitos que enquadraram o lote nestas categorias.

9.A determinação da porcentagem, para fins de verificação da Classificação, deverá ser efetuada sobre o total da amostra extraída, realizando-se o cálculo com base no número de frutos amostrados.

10. Quando forem encontrados frutos com defeitos graves e leves, deverá ser considerado o mais grave. Quando só existirem defeitos leves, será realizado o somatório dos defeitos.

11. No caso de lotes que não se enquadrarem nos requisitos acima, será permitida a reembalagem e a reclassificação, exceto em casos em que a podridão ultrapasse $10 \%$. Neste caso, o lote será descartado.

12.0 comprador terá um prazo de 24 horas para contestar a classificação. Os casos pendentes deverão ser resolvidos por agentes previamente designados pelas partes para este caso.

Figura 1. Programa brasileiro para a melhoria dos padrões comerciais e embalagens de hortigranjeiros (CEAGESP, 2000) 
EMBALAGEM

A qualidade da laranja é feita na roça. A conservação dessa qualidade exige uma embalagem que ofereça proteção, boa apresentação, informações sobre o produto, racionalização do transporte e armazenagem e gerenciamento.

Ela deve ser paletizável e pode ser descartável ou retornável. A descartável deve ser reciclável ou de incinerabilidade limpa. A embalagem retornável deve permitir higienização.

o rótulo é o certificado de origem do produto e garante sua rastreabilidade. O seu uso é obrigatório e regulamentado pelo Governo Federal. O código de barras é utilizado para a captura dos dados nos processos automatizados.

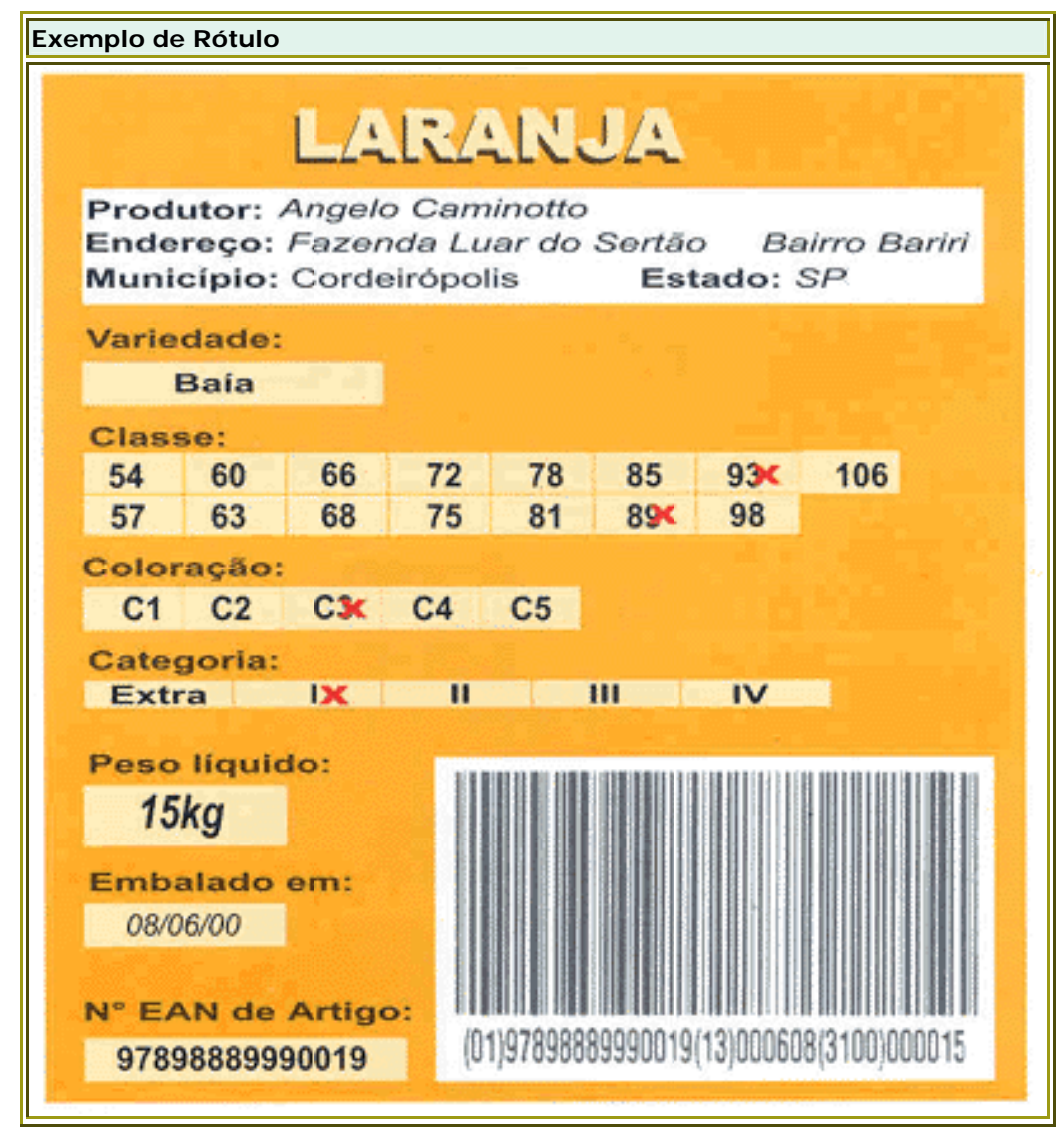

Figura 1. Programa brasileiro para a melhoria dos padrões comerciais e embalagens de hortigranjeiros (CEAGESP, 2000) 


\subsection{Qualidade da laranja}

A qualidade da laranja in natura, pode ser definida como um conjunto de características, onde devem ser considerados os atributos físicos, sensoriais e a composição química e associações ou relações entre as medidas objetivas e subjetivas. O grau de importância dos atributos individuais ou desse conjunto depende do interesse de cada grupo, como produtores, comerciantes e distribuidores que dão prioridade à aparência, alto rendimento, facilidade na colheita, transporte e armazenamento. Os consumidores visam às características sensoriais (Chitarra \& Chitarra, 1990). Pesquisas realizadas por esses autores mostram a importância do ponto de colheita na qualidade do fruto. Frutos colhidos em estágio de maturação adequado são de melhor qualidade, as propriedades organolépticas são melhores, como o aroma, sabor e maciez da polpa, apresentando tempo de vida útil relativamente prolongado. Frutos colhidos imaturos possuem maturação prejudicada e não têm valor comercial.

\subsubsection{Aparência}

Determina o valor da comercialização da laranja Pêra, podendo ser avaliada por diferentes atributos como: cor, tamanho e forma.

Cor laranja: a maturação dos frutos cítricos é caracterizada por uma fase de reduzida taxa de crescimento. Neste estágio, ocorre a mudança de cor da casca, em conseqüência da degradação enzimática das clorofilas e da síntese de carotenóides no flavedo (Figura 1).

A cor pode ser medida pro vários tipos de sistemas (Clysdale, 1978; Francis, 1980; Hunter \& Harold, 1987; Minolta, 1994). Os mais utilizados são CIEYXY, O Hunter Lab e o CIE L* a* b*, que fornecem maior uniformidade de cor em relação à percepção humana (Hunter \& Harold, 1987; Minolta, 1994).

A coloração da casca é provavelmente um fator determinante na compra da fruta pelo consumidor e também no momento da colheita, pelos produtores (Giacomino, 2002). Essa associação nem sempre pode ser considerada, pois a coloração é apenas um 
indicativo que pode mostrar falhas, como nas tangerinas 'Satsuma', que se apresentam com boas características de maturação interna dos frutos, mas a casca não se mostra ainda alaranjada (Chitarra \& Chitarra, 1990).

Reis et al (2000), concluem em seu trabalho, que a colheita de tangerinas obtidas com base na coloração intermediária e amarela, independentemente do seu tamanho, apresenta qualidade superior.

Condições climáticas também podem afetar a coloração da casca de citros, comprometendo a colheita do fruto no ponto ideal de maturação (Reis et al., 2000).

A maturação dos frutos cítricos é caracterizada por uma fase de reduzida taxa de crescimento. Nesse estágio, ocorre a mudança de cor da casca, em conseqüência da degradação enzimática das clorofilas e da síntese de carotenóides no flavedo. Esse estágio caracteriza-se também pelo aumento dos teores de sólidos solúveis totais, sobretudo açúcares, e de compostos nitrogenados, aminoácidos principalmente, e uma concomitante redução de ácidos orgânicos. A variação no teor de carotenóides totais encontrados no suco de laranja Pêra Rio é de 0,790 mg/100 ml (Sartori et al., 2002; Chitarra \& Chitarra, 1990).

A clorofila, pigmento presente em frutos jovens perde sua cor, devido às transformações no pH, decorrente do acúmulo de ácidos orgânicos e outros compostos nos vacúolos, ativação da enzima clorofilase e presença de sistemas oxidantes (Chitarra \& Chitarra, 1990).

As clorofilas (a e b) constituem a classe de pigmentos mais largamente distribuída na natureza, em folhas e frutos jovens. A perda da cor verde deve-se à decomposição estrutural desse pigmento, em decorrência de vários fatores que atuam isoladamente ou em conjunto. Dentre eles: $\mathrm{pH}$, onde há acúmulo de ácidos orgânicos e outros compostos nos vacúolos, ativação de enzima clorofilase e presença de sistemas oxidantes (Bleinroth et al., 1992; Chitarra \& Chitarra, 1990).

Outros pigmentos presentes são os carotenóides, pigmentos de cor amarela, encontrados na laranja como carotenos ou ésteres de xantofila, e a intensidade da cor depende da quantidade de pigmento presente. Eles podem estar presentes, tornando-se 
visíveis com a degradação da clorofila ou serem sintetizados com a degradação dela. (Chitarra \& Chitarra, 1990).

De acordo com Chitarra, (1979) em Chitarra, (1990), a variação no teor de carotenóides totais encontrados no suco de laranja Pêra Rio foi de 0,790 mg/100 ml.

Os principais fatores que afetam o teor de Beta-caroteno durante 0 processamento e a estocagem são a oxidação (oxigênio do ar) e mudanças estruturais provocadas pela degradação de enzimas, levando à perda da cor e valor nutritivo (Rodrigues, 1988; Rodriguez-Amaya, 1985; Sant’Ana, 1995), em Germano (2002).

A qualidade da fruta depende dos cuidados com a cultura e com o produto nas fases de colheita, beneficiamento, acondicionamento e apresentação ao mercado. Já a classificação das frutas em classes e tipos para uma interpretação uniforme (única) é obtida a partir de definição de limites ou medidas para atributos quantitativos (tamanho e peso) e qualitativos (forma, turgidez, coloração natural, grau de maturação, sinais de danos mecânicos, fisiológicos ou de pragas, presença de resíduos de produtos químicos e de sujidades) (Agência Paulista de Tecnologia dos Agronegócios-APTA, 2001).

Tamanho e Forma: o tamanho é avaliado pela circunferência, diâmetro,comprimento, largura, peso ou pelo volume. No caso da laranja Pêra, o tamanho está relacionado com o seu diâmetro equatorial, que é aquele medido transversalmente ao eixo que vai do pedúnculo ao ápice (CEAGESP, 2000).

Defeitos: as laranjas ficam imperfeitas, decorrentes de várias causas como hereditariedade, injúrias fisiológicas, ou condições ambientais desfavoráveis, manuseio inadequado resultando em deteriorações dos frutos, sabores estranhos e descoloração, reduzindo o potencial de comercialização. Na avaliação da qualidade, é determinado se o defeito é suficientemente grande para reduzir o nível de aceitabilidade do produto.

Ainda de acordo com as Normas de Classificação do CEAGESP (Figura 1), considera-se: tipo ou categoria, que são determinados pela ocorrência de defeitos graves e leves, associados aos requisitos de homogeneidade e presença de cálices nos frutos. 


\subsubsection{Textura}

É um dos atributos mais importantes, está relacionada com o sabor e aroma da laranja e estrutura do tecido, como dureza, maciez, fibrosidade, resistência e elasticidade. As modificações na textura estão relacionadas também com o teor de pectina no fruto (Chitarra \& Chitarra, 1990).

A textura pode ser avaliada por uma equipe de análise sensorial, pela associação dos sentidos: paladar, olfato e tato, cuja interação serve como medida de qualidade para os provadores, constituindo em análise subjetiva. Na análise objetiva, utiliza-se o penetrômetro, instrumento que marca numericamente a característica da firmeza da laranja.

Substâncias pécticas são os principais componentes químicos dos tecidos, responsáveis pelas mudanças de textura no fruto. A protopectina, que são grupos carboxílicos ácidos ligados ao cálcio, é insolúvel e predomina nos frutos imaturos. Com o seu amadurecimento ou armazenamento, há a liberação do cálcio e solubilização da protopectina das paredes celulares e por ação de uma enzima, sofre hidrólise parcial, produzindo ácidos pectínicos ou pécticos, resultando nas pectinas solúveis. A decomposição das moléculas poliméricas amacia as paredes celulares, diminuindo a coesão entre as células (Chitarra \& Chitarra, 1990).

Sólidos solúveis totais (SST) são compostos solúveis em água e importantes para se determinar a qualidade da fruta, consistindo numa análise objetiva destrutiva. O teor de sólidos solúveis indica quantidade de açúcares existentes na laranja, ácidos, vitaminas, aminoácidos e pectina que aumentam no processo de maturação, seja por biossíntese ou pela degradação de polissacarídeos (Kluge et al, 2002).

Os principais componentes do suco de laranja são os carboidratos: glucose, frutose e sacarose que constituem mais de 70\% dos sólidos solúveis. Em segundo, são os ácidos orgânicos, principalmente o cítrico e o málico, que representam até $10 \%$ dos sólidos solúveis. O restante é constituído por aminoácidos livres, bases nitrogenadas, íons inorgânicos, vitaminas, lipídios, flavonóides e outros (Toda Fruta, 2004). 
Para praticamente todos os frutos, quanto mais elevado o teor de sólidos solúveis, mais madura e mais doce é a amostra. Segundo Ziegler \& Wolfe (1975), o teor de SST mínimo para que o fruto possa ser considerado maduro é de $9 \%$.

\subsubsection{Sabor}

O sabor corresponde à percepção da combinação entre doçura, acidez e amargor ou adstringência. Os principais compostos químicos responsáveis pelo sabor dos frutos e hortaliças são os açúcares, ácidos orgânicos e compostos fenólicos.

Os açúcares solúveis nos frutos são responsáveis pela doçura, sabor e odor, através do balanço com ácidos, cor atrativa e textura, quando combinados com polissacarídeos estruturais. Os valores médios em frutos são da ordem de $10 \%$. As variações numa mesma espécie são decorrentes de tipos de solo, cultivares, condições climáticas e práticas culturais. Os açúcares solúveis, presentes em frutos, são a glicose, frutose e sacarose. O grau de doçura dos frutos é função da proporção dos teores desses açúcares, onde a frutose tem um poder adoçante superior ao da sacarose e glicose. A concentração de cada açúcar, isoladamente, permite o conhecimento de sua contribuição no sabor do produto. As laranjas, no entanto apresentam teores percentuais de açúcares redutores iguais a 4,7; sacarose 4,6 e açúcares totais, 9,6 (Chitarra \& Chitarra, 1990).

Os ácidos orgânicos são os sólidos solúveis presentes em maior quantidade depois dos açúcares, e têm um papel importante no sabor do suco, que está na dependência de um balanço equilibrado entre o teor de açúcares e ácidos. Os principais ácidos são: cítrico, málico e o ácido tartárico. Por causa dos sistemas tampões naturais encontrados em praticamente todos os frutos, eles podem ser acidificados por ácidos orgânicos ou inorgânicos até que o sistema tampão esteja saturado sem mostrar qualquer variação no pH. O teor de ácidos orgânicos, com poucas exceções, diminui com a maturação, em decorrência do processo respiratório ou da sua conversão em açúcares. Sendo o período da maturação o de maior atividade metabólica, os ácidos orgânicos constituem uma excelente reserva energética do fruto, através de sua oxidação no ciclo 
de Krebs. São numerosos os compostos ácidos, com natureza química variada. Os teores de acidez, em geral, não excedem 1,5 a 2 \%, com raras exceções, como em limão e espinafre que podem conter teores acima de $3 \%$ e tamarindo que pode conter até $18 \%$ (Chitarra \& Chitarra, 1990).

A relação entre o teor de sólidos solúveis ( ${ }^{\circ}$ Brix) e o teor de ácidos tituláveis é o índice utilizado para determinar o estágio de maturação (ratio). Ratio é o indicador utilizado para determinar o estágio de maturação, determinando o balanço do sabor doce: ácido. A faixa de “ratio" pode variar entre 6 e 20, sendo o intervalo de 15 a 18 o preferido pelos consumidores. A indústria inicia o processamento com valor entre $12 \mathrm{e}$ 13 (Viégas, 1991).

Na Califórnia, utiliza-se "ratio" no mínimo 8 para o consumo do fruto in natura, e 10 para frutos destinados à fabricação de suco de laranja concentrado congelado (SLCC). Na Flórida, geralmente, os consumidores preferem o suco de laranja com "ratio" entre 15 e 18, e a indústria começa a processar os frutos quando estes atingem "ratio" igual a 13 (Kimball, 1991).

No Brasil, apesar do consumo de SLCC ser pequeno (5\% do total produzido), verifica-se a preferência por sucos com "ratio" acima de 14. Todavia, o processamento pode começar quando alcançar 12 a 13. Os mesmos autores relatam que a evolução do "ratio" em laranja-doce no Estado de São Paulo, em parte, pode ser explicada pela relação porta-enxerto/copa, idade das árvores, florada e produtividade, mas que, principalmente o clima é de extrema importância na variação de ano para ano (Volpe et al, 2002).

A laranja é caracterizada como produto não climatérico, pois necessita longo período para completar o seu processo de amadurecimento, sem apresentar mudança na demanda de energia fornecida pela respiração, que se mantém em declínio contínuo até o envelhecimento. Esta fruta deve estar no ótimo de amadurecimento no momento da colheita, o que se obtém deixando-a amadurecer na planta. A melhor época, geralmente é determinada com base nas observações práticas do próprio agricultor; também pode ser determinada por métodos físicos (medição do tamanho, do diâmetro ou textura dos 
frutos) ou métodos químicos (determinação de acidez, percentagem de açúcares, amido, fibras e conteúdo de suco) (Gomes, 1996).

O momento da colheita é determinado por índices de maturação, compreendendo medidas físico-químicas que sofrem mudanças perceptíveis ao longo da maturação da fruta, obtendo-se desta forma frutas de boa qualidade, saborosas e outras características sensoriais (Kluge et al., 2002).

Sartori et al (2002) consideram como maduros, e adequados para o consumo, frutos que apresentam SST/ATT entre 8,8 e 15,4.

Manica (1966), classifica a relação SST/ATT de acordo com as zonas produtoras: para a zona do Planalto Paulista e Sul do Brasil, a relação ideal para consumo de laranja é de 6,5:1; e, para o Litoral Brasileiro e Baixada Fluminense, a relação é de 8:1.

Compostos fenólicos: as substâncias fenólicas (compostos fenólicos) e derivados são largamente distribuídos na natureza, principalmente nos vegetais podendo ocorrer também nos fungos, bactérias e animais. Nos vegetais estão presentes nas folhas, flores, sementes, pólen, tubérculos, raízes e tecidos lenhosos, desempenhando diversas funções como coloração, inibidores de germinação, reserva de carboidratos, ação antisséptica e outras (Ranzani e Prado,1991).

A hesperidina pertence ao grupo de componentes denominados flavonóides, como a naringina. Estes dois elementos característicos aparecem no suco de laranjas doces (Pêra e tangerinas) e não conferem sabor ao fruto, encontrada na membrana da casca, não é solúvel em soluções aquosas neutras e é levemente solúvel em soluções ácidas no suco cítrico, contribuindo neste caso com 10 a 25\% da turbidez. Aparecem em forma de filmes, cristais ou flocos nos sucos concentrados ou reconstituídos. Os valores da hesperidina geralmente diminuem com a maturação do fruto, diluindo-se mais (Kimball,1991).

A aceitabilidade e palatabilidade dos frutos e seus produtos dependem do tipo e da concentração dos compostos adstringentes presentes. A adstringência é associada aos compostos fenólicos. A sensação de adstringência ocorre devido à coagulação das proteínas da saliva e epitélio mucoso, por combinação com a substância adstringente. A 
ocorrência das substâncias fenólicas em alguns alimentos é benéfica e em outros pode ser deletéria. As mudanças que ocorrem no armazenamento, pós-colheita e processamento de frutas frescas, cereais e legumes estão relacionados aos compostos fenólicos, podendo conferir adstringência ao alimento onde o ácido tânico é comum em frutas imaturas e com o passar do tempo, durante a maturação, diminui o seu teor devido à polimerização ou condensação dos compostos fenólicos (Kluge et al., 2002).

Conforme Food and Nutrition Information Center, USDA (2003), os valores médios dos teores obtidos para suco de laranja da hesperidina é de 12,54 mg/100g (mínimo de 4,93 e máximo 39.20mg/100g) e naringenina de 2,27 mg/100g (mínimo de 0,00 e máximo 6,37 mg/100g). O total do conteúdo de flavonóides (flavonas, flavonols e flavanonas), no suco de laranja, pode variar de um mínimo de 4,98 mg/100g a $42,47 \mathrm{mg} / 100 \mathrm{~g}$.

\subsubsection{Aroma}

É o conjunto das sensações de olfato, estimuladas por componentes voláteis que, em conjunto com o gosto, conferem características específicas ao produto (Chitarra e Chitarra, 1990). Os órgãos do olfato localizados acima da cavidade nasal (epitélio olfativo), normalmente só são atingidos por gases ou vapores, apresentando alta sensibilidade a pequenos limiares nas concentrações de substâncias voláteis, na ordem de 0,001ppm. Assim, os frutos rejeitados pelo consumidor apresentam-se, por exemplo, verdes, supermaduros ou ainda com início de fermentação.

O ácido ascórbico (L-ácido ascórbico), vitamina C, é uma substância inodora, um sólido cristalino branco que se funde a $190-192^{\circ} \mathrm{C}$. Tem um gosto ligeiramente ácido, é solúvel em água quando são dissolvidos 33g em 100 ml e também solúvel em álcool (2g em 100ml), mas insolúvel nos solventes orgânicos comuns. Tem uma absorção máxima de 265nm em uma estreita faixa entre 350 e 400nm (Jacobs, 1958).

A laranja Pêra, Citrus sinensis L. Osbeck, é considerada como a laranja do grupo “sour” ácidas. Harding \& Winston, 1939 citado por Sinclair, 1984, pesquisaram as concentrações de ácido ascórbico em várias frutas cítricas, entre elas a laranja Valência, 
considerada ácida do grupo "sour”, detectando 42.5mg / $100 \mathrm{ml}$ na fruta colhida à sombra e $54 \mathrm{mg} / 100 \mathrm{ml}$ na fruta exposta ao sol.

A concentração de ácido ascórbico, nas frutas cítricas, depende da variedade, idade, tipo de tecido na fruta, clima, mudanças climáticas, diferentes exposições da fruta à luz solar, entre outras. Segundo Souci et al (1999), o teor de vitamina C deve variar de 36 a 50 mg/100g de amostra de suco de laranja Pêra.

\subsection{A origem dos frutos analisados}

As laranjas Pêra analisadas neste trabalho, vieram de duas regiões distintas do estado de São Paulo. Segundo a classificação climática de Köeppen (Russo Júnior, 1980), o tipo climático característico dessas duas regiões é o Aw. Para a primeira região, a de Barretos, é caracterizada pelo clima tropical, com inverno seco e para a segunda região, a de Limeira, é classificada como Cwa, com verão quente e inverno seco. Para as duas regiões, a temperatura média do mês mais quente é de $22^{\circ} \mathrm{C}$ e do mês mais frio, a média é de $18^{\circ} \mathrm{C}$. O total de chuvas do mês mais seco é de $30 \mathrm{~mm}$ para ambas as regiões.

\subsection{Análise Descritiva Quantitativa}

Na Indústria de Alimentos, o uso de técnicas modernas de Análise Sensorial tem sido um meio seguro para caracterizar diferenças e similaridades entre produtos que disputam um mesmo mercado consumidor. Essas técnicas otimizam atributos de aparência, aroma, sabor e textura de alimentos em função de expectativas do mercado consumidor e avaliam alterações sensoriais que ocorrem em função do tempo, condições de armazenamento, tipos de embalagem, etc.

A formação de equipe adequada para cada tipo de análise, formada por provadores treinados, determina o êxito das análises, juntamente na escolha do teste a 
ser empregado. A análise dos resultados fundamenta-se em literatura e metodologia, apropriadas aos objetivos de estudo, tratando estatisticamente os dados obtidos A Análise Descritiva Quantitativa (ADQ) proporciona uma completa descrição de todas as propriedades sensoriais de um produto, representando um dos métodos mais completos e sofisticados, para a caracterização sensorial de atributos importantes. Esse método é de grande valia, já que trabalha com provadores exaustivamente treinados através dos próprios atributos do produto em questão. Esses provadores devem, portanto, ser capazes de detectar e descrever as características sensoriais de uma amostra, definindo os atributos e diferenciá-los de outros, assim como indicar a intensidade com que o atributo é percebido nas amostras.

A ADQ é apropriada quando se requer informações detalhadas sobre atributos de um produto, como a documentação das características sensoriais, identificação e quantificação dos atributos para a orientação de uma pesquisa, manutenção ou comparação entre produtos similares, correlações entre medidas instrumentais, determinações químicas com respostas sensoriais e definição de um padrão ou referência para o controle de qualidade de um determinado produto (Meilgaard et al. 1991).

As vantagens da ADQ sobre os outros métodos de avaliações são a confiança no julgamento de uma equipe composta por provadores treinados, ao invés de alguns poucos especialistas; desenvolvimento de uma linguagem descritiva objetiva, mais próxima à linguagem do consumidor, desenvolvimento consensual da terminologia descritiva a ser utilizada que implica em maior concordância de julgamentos entre os provadores resultados estatisticamente analisados (Behrens e Silva, 2000).

A Análise Descritiva Quantitativa é ferramenta valiosa para aumentar a informação sobre a aparência, aroma, sabor e textura dos produtos e utilizada efetivamente para produtos e processos em desenvolvimento, estudos de prateleira, controle de qualidade e correlações objetivo-subjetivas nas avaliações de alimentos (Stone et al., 1974). 


\subsection{QFD e o Planejamento da Qualidade}

Por volta de 1978, o método QFD (Quality Function Deployment) foi reconhecido como o método que operacionaliza o planejamento da qualidade ou a gestão do desenvolvimento do produto, podendo ser aplicado tanto ao produto (bens e serviços) da empresa quanto ao produto intermediário entre cliente e fornecedor interno.

Esse método visa desdobrar a qualidade, utilizando a lógica da causa e efeito, de forma sistematizada. O desdobramento parte da voz do cliente, passando por características da qualidade do produto até chegar a um determinado valor de um parâmetro de controle do Padrão Técnico de Processo. Por Desdobramento da Qualidade entende-se: buscar, traduzir e transmitir as exigências dos clientes em características da qualidade do produto, por intermédio de desdobramentos sistemáticos, iniciando-se com a determinação da voz do cliente, passando pelo estabelecimento de funções, mecanismos, componentes, processos, matéria-prima e estendendo-se até o estabelecimento dos valores dos parâmetros de controle dos processos. O método Desdobramento da Função Qualidade (QFD) é indicado para operacionalizar o "planejar a qualidade” (tipo de melhoria que exige inovação), com a finalidade de estabelecer um novo sistema de padrões (CHENG et al., 1995).

A ação gerencial do planejamento da qualidade é constituída das seguintes etapas: 1. identificar as necessidades do cliente (qualidade, custo e entrega); 2. estabelecer o conceito do produto; 3. projetar o produto e o processo; 4. estabelecer os padrões-resposta; 5 . fabricar e testar o lote piloto; 6. verificar a satisfação do cliente; 7. estabelecer a padronização final; 8. reflexão sobre o processo de desenvolvimento.

Mattar (1999), localiza a metodologia para obtenção de dados de uma pesquisa de marketing dentro da etapa de seu planejamento. No tocante às fontes de dados, afirma que em sua determinação pode-se optar por fontes primárias de dados ou por dados secundários. São denominadas fontes primárias as que são portadoras de dados brutos, que nunca foram coletados, tabulados e analisados, são os consumidores, telespectadores, radiouvintes, intermediários, leitores e outros. Denominam-se dados secundários aqueles que já foram coletados, tabulados e analisados e que já estão 
disponíveis para consulta. Conta-se com várias fontes de dados secundários, como IBGE, Fundação SEADE, FIPE, FGV, relatórios de pesquisa, jornais, revistas, livros e outros. Após a identificação da fonte de dados adequada, é necessário definir a metodologia de pesquisa, devendo-se selecionar o tipo de pesquisa mais conveniente para a obtenção de informação. Cita a existência de pesquisa exploratória, pesquisa conclusiva descritiva (ou, simplesmente pesquisa descritiva) e pesquisa conclusiva causal (ou, simplesmente, pesquisa causal). A pesquisa exploratória visa prover o pesquisador de um maior conhecimento sobre o assunto de pesquisa focado, sendo apropriada para os primeiros estágios da investigação. As pesquisas descritivas apresentam objetivos bem definidos, procedimentos formais, são bem estruturadas e direcionadas à solução do problema em questão, são utilizados quando se pretende: descrever as características de grupos; estimar a proporção de indivíduos numa população de indivíduos numa população especifica que apresenta determinadas características ou comportamentos; e, descobrir ou verificar a existência de relação entre variáveis.

Segundo Kirk \& Miller (1986), citado por Mattar (1999), tecnicamente a pesquisa qualitativa identifica a presença ou ausência de algo, enquanto a quantitativa procura medir o grau em que algo está presente. Podem-se apontar diferenças metodológicas: com a obtenção dos dados de um grande número de respondentes na pesquisa quantitativa, usando-se escalas, geralmente, numéricas, que são submetidas a análises estatísticas formais; enquanto que na pesquisa qualitativa, os dados são colhidos através de perguntas abertas (em questionários), em entrevistas em grupos, em entrevistas individuais em profundidade e em testes projetivos.

Quanto à forma utilizada para a coleta de dados primários, Mattar (1999), afirma que a mais tradicional e corriqueira é através da comunicação com o detentor dos dados, sendo o dado obtido pela declaração do próprio respondente, o que caracteriza o uso de entrevistas e o emprego de questionários. 


\subsubsection{O consumidor}

Em recente pesquisa publicada na Revista FrutiFatos (Brasil, 2002) com dados sobre consumidores da Grande São Paulo e interior, constatou-se que 79\% dos consumidores de frutas, legumes e verduras (FLV) entrevistados são do sexo feminino, com pequena variação entre a capital e o interior. Os especialistas afirmam que as mulheres são mais exigentes que os homens no ato da compra. O homem adquire o produto, a mulher a utilidade. Dos entrevistados na pesquisa, $62 \%$ têm menos de 40 anos; 26\% têm de 41 a 50 anos; e 12\% de 50 a 60 anos.

Considerando todas as pessoas, a renda média da população pesquisada gira em torno de R 1.650,00, com diferença para mais na Grande São Paulo. Por classe social, identificou-se que a renda média das classes A e B gira em torno de R\$2.760,00, enquanto nas classes de menor poder aquisitivo, a renda cai para $\mathrm{R} \$ 880,00$. A renda familiar média dos homens pesquisados tende a ser superior à renda das mulheres, assim como entre os consumidores de maior faixa etária.

Cada família paulista gasta, em média, R\$ 86,70 por mês na compra de hortifrutis para consumo domiciliar. O gasto é pouco maior na Grande São Paulo - R\$ 88,50/mês; nas classes de maior poder aquisitivo - R \$ 101,70/mês; nas famílias em que os homens são responsáveis pelas compras - R\$ 94,60/mês; e entre os consumidores de mais idade $\mathrm{R}$ \$ 95,00/mês, aparentemente pelo cuidado de manter uma alimentação mais saudável.

Segundo Brasil (2002), os consumidores não estão satisfeitos com o desempenho dos supermercados. A julgar pelo desempenho do passado recente, o futuro promete. Cerca de $40 \%$ das pessoas ouvidas na entrevista aumentaram seu consumo de FLV no último ano e quase 50\% mantiveram o consumo anterior. Esses dados acompanham a tendência mundial em busca de melhor qualidade de vida, diretamente associada à melhor alimentação.

A pesquisa realizada pela Secretaria de Infraestrutura Hídrica (Brasil, 2002) constatou que o consumo de frutas, legumes e verduras é motivado fundamentalmente pelo valor nutricional que agrega à alimentação, promovendo um melhor estado de 
saúde para seus consumidores. Os consumidores ouvidos indicaram também, como razões de consumo, qualidade, sabor, higiene, aparência e frescor dos produtos. Do total das pessoas consultadas, apenas $10,7 \%$ estão satisfeitas com o desempenho dos supermercados.

Os consumidores apontaram como principais problemas na hora da compra de FLV: o preço (19,1\% dos entrevistados), a falta do produto (16,8\%), pouca variedade (11,7\%), mancha/deformação/lesão (11,3\%), produtos passados $(9,8 \%)$ e produtos estragados (9,0\%). Na soma, 28,6\% dos entrevistados indicaram falta de produtos ou pouca variedade como principais problemas. É a prova definitiva da ineficiência de programação dos supermercados, que leva o consumidor na hora das compras a se sentir frustrado (Brasil, 2002). 


\section{MATERIAL E MÉTODOS}

\subsection{As análises físico-químicas da laranja Pêra}

O trabalho foi desenvolvido nos laboratórios do Departamento de Agroindústria Alimentos e Nutrição da Escola Superior de Agricultura "Luiz de Queiroz" e Companhia de Entrepostos e Armazéns Gerais do Estado de São Paulo (CEAGESP).

As laranjas foram obtidas com todas as informações necessárias em diferentes fases de maturação da variedade Pêra, conforme informação do produtor e classificação realizada pela CEAGESP (Figura 1).

Foram estudados os frutos de Barretos e Limeira, por provirem de regiões de climas diferentes, ocasionando alterações nas suas colorações. As laranjas foram avaliadas durante a época de safra, setembro-dezembro, para a região de Barretos e entre-safra, maio-julho, para a região de Limeira.

As informações sobre a região de produção, épocas de plantio e colheita, bem como as condições de transporte, packing house e sistema de embalagem, foram fornecidas pelo Centro de Qualidade em Horticultura da CEAGESP (Figura 2).

Somente as informações do produtor de Barretos puderam ser divulgadas, devido à falta de informações precisas do produtor de Limeira. 
DATA: 20/10/2003

INFORMAÇÕES SOBRE A CULTURA:

1. PRODUTOR: LUIZ IANNINI

2. REGIÃO (ESTADO E CIDADE): BARRETOS-SP

3. CLIMA DA REGIÃO (CARACTERIZAR): MUITO SECO, CLIMA SECO DEFINIDO E LONGO.

4. TIPO DE FRUTA (VARIEDADE): PERA RIO

5. DENSIDADE E ORIENTAÇÃO DE PLANTIO (AERAÇÃO E ILUMINAÇÃO) COMO SÃO? 7.00m X $4.5 \mathrm{~m}$

6. IDADE DO POMAR: 12 ANOS

7. PORTA-ENXERTO ADOTADO: LIMÃO CRAVO/TANGERINA CLEÓPATRA

8. TIPO DE SOLO, FERTILIDADE, PRODUNDIDADE, DRENAGEM E TEXTURA: LATOSSOLO FASE ARENOSA.

9. TEM PROBLEMAS COM EROSÃO (CONTROLE)? NÃO

10. QUAL É A COBERTURA VEGETAL NAS ENTRELINAS, TEM ROTAÇÃO DE CULTURA? BRACHIARIA

11. ADUBAÇÃO (COMO, QUANDO, QUANTO E O QUE É APLICADO?): DEPENDE DA ANÁLISE DE SOLO, VARIA DE ANO PARA ANO

12. A PROPRIEDADE UTILIZA POLINIZADORES? ABELHA

13. DISPONIBILIDADE DE ÁGUA (CHUVAS OU IRRIGAÇÃO):

14. SE FOR FEITO, QUAL É O SISTEMA DE IRRIGAÇÃO ADOTADO? MICROASPERSÃO

15. COMO É FEITO O MANEJO DE PROGAS E DOENÇAS? (VARIEDADE RESISTENTE, INSETICIDA, FUNGICIDA E CONTROLE BIOLÓGICO): TODOS.

16. QUAL O CRITÉRIO UTILIZADO PARA A COLHEITA? (DEGUSTAÇÃO NO POMAR, BRIX, TAMANHO, COLORAÇÃO, DIAS DEPOIS DA FLORADA). O QUE VISA O PRODUTOR NA COLHEITA? (DURABILIDADE E FIRMEZA OU SABOR): TAMANHO, COLORAÇÃO.

17. TEMPO E CONDIÇÕES DE TRANSPORTE E ARMAZENAMENTO: DEPOIS DE COLHIDA CHEGA DOIS DIAS DEPOIS NO CENTRO ATACADISTA

18. QUANTO PRODUZ POR SAFRA? CERCA DE 40 TON/HA

19. FORMA DE EXPOSIÇÃO, EMBALAGEM (CAIXAS OU A GRANEL): CAIXA.

Figura 2. Ficha da laranja Pêra para acompanhamento de produção e qualidade da fruta em região de Barretos, SP 
Para o delineamento experimental foram utilizados blocos casualizados (Cochran \& Cox, 1957), com 12 coletas, cada lote de amostra foi composto por 36 frutos, totalizando 432 frutos.

Os 6 lotes de laranjas, provenientes da Região de Barretos, chegaram ao Departamento de Agroindústria, Alimentos e Nutrição nos dias 24 de setembro, 3 de outubro, 17 de outubro, 13 de novembro, 11 de dezembro e 15 de dezembro, onde foram analisadas.

As laranjas oriundas da região de Limeira chegaram ao Departamento de Agroindústria Alimentos e Nutrição, nos dias 12 de maio (2 lotes com 2 tipos de coloração); 26 de maio (2 lotes - 2 tipos de coloração) e 13 de julho (2 lotes - 2 tipos de coloração).

Das caixas de 40,8 kg, foram retiradas amostras aleatoriamente para as análises físico-químicas e sensoriais. As amostras destinadas às análises de cor do flavedo e firmeza do albedo foram realizadas no Centro de Energia Nuclear de Agricultura da Universidade de São Paulo.

\subsubsection{Análises físicas}

As análises físicas da laranja Pêra foram caracterizadas com o objetivo de se avaliar seus valores numéricos em firmeza, cor e densidade. As amostras foram feitas em triplicatas.

\subsubsection{Firmeza}

Realizada com penetrômetro Fruit Pressure Test, modelo FT 327 (3-27lb), da EFFEGI. As medições foram feitas em 12 frutos, com 2 medições por fruto, diametralmente opostos.

O penetrômetro consiste de um êmbolo (variando em diâmetro) preso a uma mola calibrada dentro de uma conexão graduada em polegadas. Quando o êmbolo é pressionado para penetrar no fruto ou hortaliça, a mola se contrai e um indicador mostra 
as polegadas requeridas através de uma dada distância. Em geral os penetrômetros fazem leituras em libras ou em kilograma-força. Neste caso, converteram-se os valores para Newton, multiplicando-se a leitura por 1,951 (para a laranja, o diâmetro da peça de inserção utilizado foi de $8 \mathrm{~mm}$ ).

\subsubsection{Cor}

Avaliada em colorímetro Color-Meter-Minolta 200b. Foram considerados 12 frutos por tratamento e 2 leituras em lados opostos de cada fruto, segundo Sacks e Shaw (1994). As leituras foram obtidas pelos valores de L Hunter (Luminosidade), a* Hunter (vermelho ao verde) e b* Hunter (amarelo ao azul).

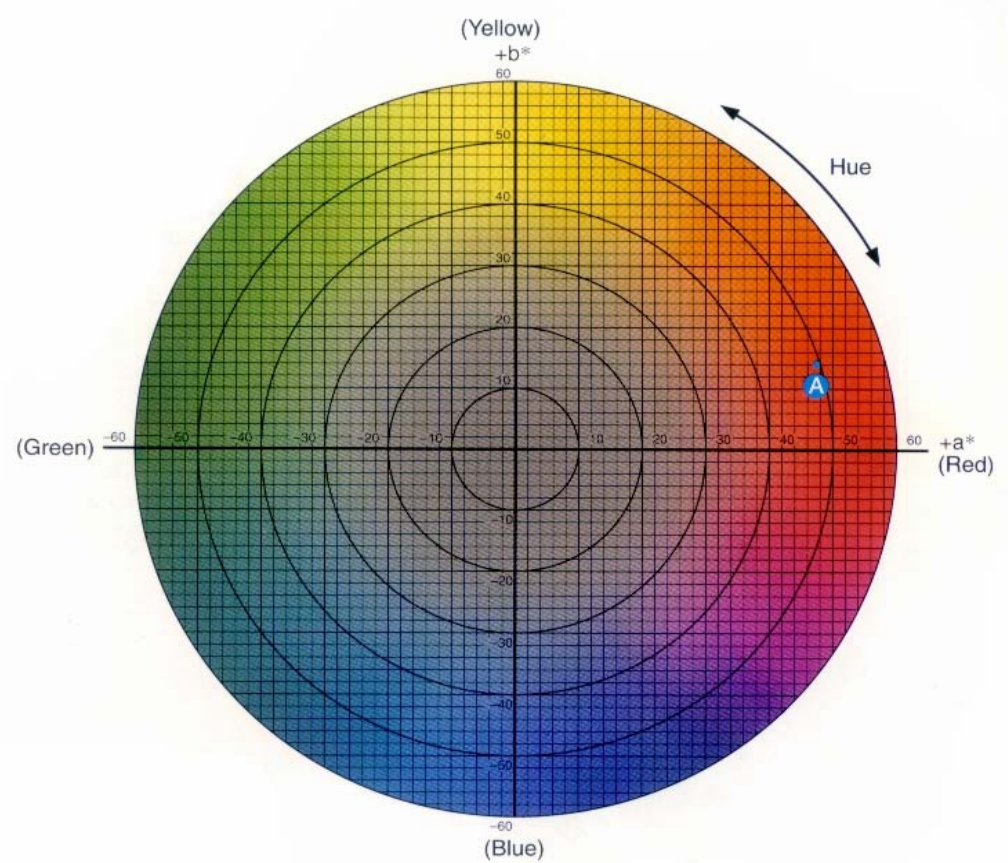

Figura 3. Disco de cores 


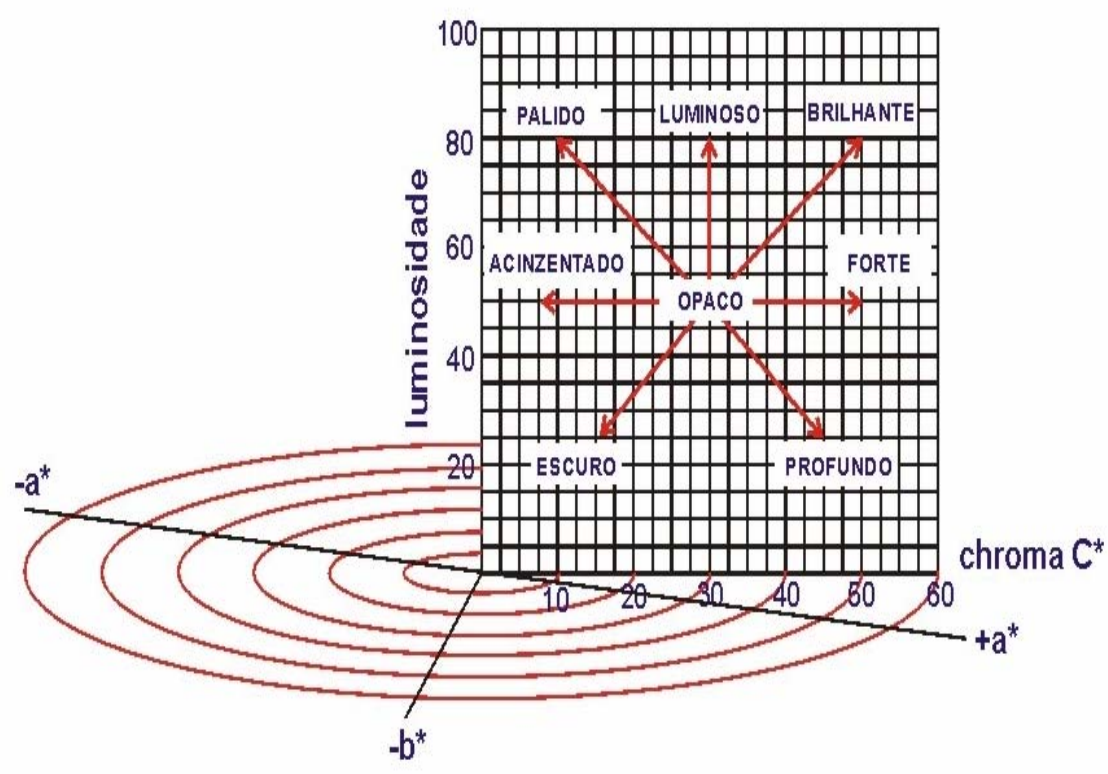

Figura 4. Escala de cores com L Hunter Luminosidade, a* Hunter (vermelho ao verde) e b* Hunter (amarelo ao azul)

\subsubsection{Densidade}

O peso específico da laranja foi realizado mergulhando-a em volume de água previamente medida, em provetas, observando o seu deslocamento. A fórmula foi fornecida através da fração entre o peso da fruta e o volume de água deslocada.

\subsubsection{Análises químicas}

Amostras foram feitas em triplicatas.

\subsubsection{1 pH}

Avaliado em potenciômetro DIGIMED modelo DMPH, com amostras liquefeitas de acordo com a AOAC (1992). 


\subsubsection{Teor de sólidos solúveis totais (SST)}

Medidos em refratômetro Auto Abbe, modelo. 10500/10501, Leica, com o resultado expresso em graus Brix (AOAC, 1992). O procedimento consistiu em misturar e homogeneizar completamente a amostra; foram colocadas duas alíquotas de $0,1 \mathrm{ml}$ da mistura no refratômetro e ler o resultado.

\subsubsection{Acidez total titulável (ATT)}

A acidez total titulável (ATT) foi avaliada mediante titulação do suco com $\mathrm{NaOH}$ a 0,1 N /100 ml suco e expressa em \% de ácido cítrico (AOAC, 1992).

Pesou-se 10 g de amostra em triplicatas e acrescentou-se $100 \mathrm{ml}$ de água em cada uma. Titulou-se com solução de $\mathrm{NaOH}$ 0,1 N até pH 8,2 (referente ao pH de mudança de coloração do indicador fenolftaleína).

\subsubsection{Razão sólidos solúveis/acidez titulável (Ratio)}

Calculado através da relação entre o teor de sólidos solúveis e acidez titulável, cujo fator é multiplicado por 100, resultando em porcentagem.

\subsubsection{Açúcares redutores (glicose e frutose) e totais (sacarose e redutores)}

Avaliados segundo Lane-Eyon (Henry \& Eyon, 1934).

Em balança digital, foram pesados $20 \mathrm{~g}$ de suco (filtrado em algodão) em balão volumétrico de $200 \mathrm{ml}$; completou-se o volume do balão com água destilada à marca da aferição; o filtrado foi homogeneizado e transferidos $20 \mathrm{ml}$ desse diluído para balão volumétrico de $200 \mathrm{ml}$; adicionou-se $20 \mathrm{ml}$ de água destilada e aqueceu-se em banhomaria até temperatura de $65^{\circ} \mathrm{C}$; ao volume aquecido foram adicionados $10 \mathrm{ml}$ de solução de ácido clorídrico 6,34 N; foi neutralizado com solução de $\mathrm{NaOH}$ a $20 \%$. Foram pipetados $5 \mathrm{ml}$ de solução de Fehling A e $5 \mathrm{ml}$ da solução de Fehling B em erlenmeyers de 250 ml; adicionou-se $50 \mathrm{ml}$ de água destilada até a ebulição; adicionou-se 3 gotas do indicador Azul de metileno a 1\%; titulou-se gota-a-gota com a solução da bureta. 
Cálculos:

AT\% caldo $=\underline{496,44}+0,605$

$\mathrm{Vxf}$

$\mathrm{V}=$ Volume gasto na bureta

$\mathrm{f}=$ fator de correção do licor Fehling =25,64/V

Este método tem como princípio considerar açúcares redutores todos aqueles açúcares, como glicose e frutose, capazes de reduzir o cobre presente em soluções cupro-alcalinas, passando da forma $\mathrm{Cu}^{+2}$ para a forma $\mathrm{Cu}^{+}$. Os açúcares são oxidados a ácidos orgânicos, em reação que não é estequiométrica, onde se mantém a mesma proporcionalidade entre as quantidades de açúcares redutores e cobre reduzido. Essa relação empírica pode ser utilizada para se calcular a quantidade de açúcar redutor em uma solução necessária para reduzir, a quente, o cobre presente na forma de íons cúpricos em uma solução alcalina estabelecidas por tartaratos. Neste método, utiliza-se um volume exato de Licor de Fehling (solução cupro-alcalina), de concentração conhecida em íons cúpricos e, sabendo-se previamente a quantidade de açúcares redutores necessária para reduzir completamente esse cobre, de acordo com o volume de solução dos açúcares gastos, determina-se a concentração de açúcares redutores totais na amostra.

\subsubsection{Clorofila}

A clorofila foi avaliada, pesando-se aproximadamente $2 \mathrm{~g}$ da amostra, triturandose e acrescentando-se $18 \mathrm{ml}$ de acetona $80 \%$. A seguir, a mistura foi filtrada em ambiente sem iluminação. A leitura do sobrenadante foi realizada em espectrofotômetro a $663 \mathrm{~nm}$ (clorofila a) e $646 \mathrm{~nm}$ (clorofila b). Os teores de clorofila foram calculados pelas equações de Lichtenthaler (1987):

Clorofila a $(\mathrm{Ca})=12,25 \times \mathrm{A}_{663}-2,79 \times \mathrm{A}_{646}$

Clorofila b (Cb) $=21,50 \times \mathrm{A}_{646}-5,10 \times \mathrm{A}_{663}$

Clorofila total $(\mathrm{Ct})=7,15 \times \mathrm{A}_{663}+18,71 \times \mathrm{A}_{646}$; 


\subsubsection{Carotenóides}

O teor de carotenóides foi determinado através da leitura do mesmo sobrenadante obtido na análise de clorofila, alterando-se o comprimento de onda no espectrofotômetro para $470 \mathrm{~nm}$. O teor de carotenóides foi expresso em $\mathrm{mg} / \mathrm{ml}$, calculado através da fórmula de Lichtenthaler (1987).

Carotenóides (C) = [1000 x A $470-(1,82 \times \mathrm{Ca}+85,02 \times \mathrm{Cb})] / 198$;

$\mathrm{A}_{470}=$ leitura no espectrofotômetro;

$\mathrm{Ca}=$ teor de clorofila $\mathrm{a}$;

$\mathrm{Cb}=$ teor de clorofila $\mathrm{b}$

\subsubsection{Substâncias pécticas}

As pectinas totais e solúveis foram extraídas por método de Mc Cread \& Mc Comb (1952). Na dosagem foi utilizada a técnica de Bitter \& Muir (1962) com resultados em mg de ácido galacturônico / $100 \mathrm{~g}$ de peso fresco. A porcentagem de solubilidade foi obtida pela porcentagem de pectina solúvel em relação à pectina total.

Para a extração da pectina solúvel do caldo da laranja, tomou-se 5 g da amostra e foram retirados os açúcares com solução de álcool etílico a 75\%, deixando 1 h sob agitação. Em seguida, filtrou-se a amostra, dilui-se o filtrado e tomou-se alíquota para doseamento.

Para a determinação da pectina total, prosseguiu-se com o mesmo procedimento, tomando-se $5 \mathrm{~g}$ da amostra. Adicionou-se solução extratora Versene. Adicionou-se pectinase de fungo (origem: Aspergillus niger. Merck - 1,0 U/mg - EC 3.2.1.15.

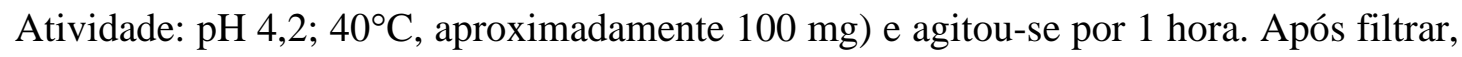
tomou-se alíquota para doseamento.

Os padrões e as amostras contendo entre 5 e $75 \mu \mathrm{g} / \mathrm{ml}$ de ácido urônico (neste caso de experimento com a laranja Pêra, foram utilizados $60 \mu \mathrm{g} / \mathrm{ml}$ de ácido galacturônico) em tubos de ensaio (16 X $150 \mathrm{~mm}$ ) e colocados em banho água-gelo. Esfriou-se por diversos minutos e acrescentou-se 3,6 ml da solução $\mathrm{H}_{2} \mathrm{SO}_{4}$ /tetraborato no tubo mantido dentro do banho de água-gelo. Homogenizou-se cuidadosamente o conteúdo num Vórtex a velocidade moderada. Em seguida, aqueceu-se os tubos a $100^{\circ} \mathrm{C}$ 
em banho-maria por 5 minutos e imediatamente esfriados em banho de gelo-água. Uma alíquota de $60 \mu \mathrm{l}$ de m-hidroxidifenil 0,15\% é acrescentada para desenvolver cor. Os valores de absorbância são estáveis por até 1 hora. As medidas de absorbância foram feitas a $520 \mathrm{~nm}$ no espectrofotômetro.

\subsubsection{Vitamina $C$}

Determinação de ácido ascórbico, por método de titulação, utilizando-se 2,6diclorobenzenoindofenol (Jacobs, 1956; Leme \& Malavolta, 1950).

O método baseia-se na redução do indicador 2-6 diclorobenzenoindofenol de cor azul para produto incolor pelo ácido ascórbico (Jacobs, 1958). Para se evitar a perda de vitamina C, a extração das amostras é feita com solução de ácido oxálico 0,4\%. Os resultados foram expressos em $\mathrm{mg}$ de vitamina $\mathrm{C} / 100 \mathrm{ml}$ de suco.

O procedimento iniciou-se com a extração do suco das laranjas, manualmente e em seguida foram diluídos $25 \mathrm{ml}$ deste suco em $25 \mathrm{ml}$ de ácido oxálico. As amostras foram realizadas em triplicatas. Filtrou-se em papel de filtro contendo celite, para remover turvação e coloração.

Transferiu-se $2 \mathrm{ml}$ do filtrado para enlenmeyer de $125 \mathrm{ml}$ e adicionou-se cerca de $50 \mathrm{ml}$ de água destilada. Em seguida, titulou-se a solução de 2,6 diclorobenzenoindofenol até a coloração rosa claro e anotou-se o volume gasto. Titulou-se $2 \mathrm{ml}$ de solução padrão de ácido ascórbico, diluída em 50 ml de água com o indicador.

Os resultados foram expressos em mg de vitamina $\mathrm{C} / 100 \mathrm{ml}$ de suco.

\subsubsection{Compostos Fenólicos}

Os compostos fenólicos totais foram extraídos com metanol a 80\% e determinados pelo Método Colorimétrico de Follin-Dennis segundo Swain \& Hillis (Swain \& Hillis, 1959). A leitura foi realizada a $760 \mathrm{~nm}$ em espectrofotômetro e os resultados foram expressos em mg de ácido tânico por 100 g de suco (AOAC, 1992), com modificações.

Pesou-se $6 \mathrm{~g}$ da amostra em béquer de. Colocou-se em seguida $80 \mathrm{ml}$ de metanol a 80\% e agitou-se por 60 minutos. A amostra não foi centrifugada, pois os sólidos já 
ficaram em suspensão. Foi filtrado em papel de filtro ou algodão em balão de $100 \mathrm{ml}$. Completou-se o volume com metanol 80\% e agitou-se. Foram feitos 3 tubos para cada amostra mais um branco (para o branco substituiu-se a solução do balão por $500 \mu \mathrm{l}$ de metanol). Pipetou-se $8 \mathrm{ml}$ de água, mais $500 \mu \mathrm{l}$ da solução do balão e em seguida $500 \mu \mathrm{l}$ de Folin-Dennis (conservado em geladeira); $1000 \mu \mathrm{l}$ de solução saturada de carbonato de cálcio foram adicionados após 3 minutos da adição do reagente Follin-Dennis. Em seguida agitou-se, foi deixada em repouso por 60 minutos e foi feita a leitura.

\subsection{Análise Sensorial}

A análise sensorial foi conduzida aplicando-se métodos analíticos de diferença para a seleção de provadores e método descritivo para medir a qualidade do fruto. A equipe de provadores composta de 3 homens e 7 mulheres, na faixa etária de 20 a 50 anos, constituiu-se de pesquisadores, técnicos e estagiários da seção.

A seleção dos provadores foi realizada em 3 etapas distintas:

$1^{a}$ Etapa - Recrutamento: etapa na qual se fez o primeiro contato com os provadores, obtendo-se informações sobre interesse, disponibilidade de tempo, afinidade pelo produto, idade, sexo e outros quesitos; os dados foram levantados através da ficha de recrutamento (Figura 5). 
Nome:

Data:

Estamos recrutando provadores para compor uma equipe para análise sensorial de frutas, os quais serão treinados para as análises durante o ano de 2003. Serão realizados vários testes, sendo necessária a presença do provador quando solicitado.

1. Você tem interesse em ser provador?

2. Você tem tempo disponível (15 a 30 minutos por semana)? Quando pretende tirar férias?

3. Você gosta de frutas? Tem alguma que você não goste?

4. Fumante: $\square$ sim; $\square$ não

5. Telefone:

6. e-mail:

7. Faixa etária: $\square 18$ a 25 anos; $\square$ de 26 a 40 anos; $\square$ acima de 40 anos.

8. Sexo: $\square$ Feminino; $\square$ Masculino.

Obrigado por sua atenção!

Figura 5. Ficha de recrutamento de provadores

Foram entrevistados 18 provadores e recrutados 14 para a segunda fase da seleção. Os reprovados foram devido à indisponibilidade de tempo e fumantes.

$2^{a}$ Etapa - Teste de reconhecimento de gostos básicos: para essa fase do teste, utilizaram-se como materiais soluções quimicamente puras dos gostos básicos: doce (0,14\% de sacarose), ácido (0,07\% de ácido cítrico), salgado (0,5\% de cloreto de sódio) e amargo (0,07\% de cafeína) e água mineral. Foram oferecidos $25 \mathrm{ml}$ de cada solução 
aos provadores em copos plásticos descartáveis, codificados com números aleatórios de 3 algarismos. O reconhecimento dos gostos básicos foi conduzido em sala com temperatura controlada $\left(22^{\circ} \mathrm{C}\right)$, estando os provadores individualizados em cabines, contendo bandejas com as amostras, fichas de avaliação, conforme Figura 6, e copos com água para lavagem da boca entre as avaliações. Todos os provadores apresentaram $100 \%$ de acertos.

Nome: Data:

Por favor, prove as amostras, da esquerda para a direita, identificando os gostos básicos (ácido, doce, salgado e amargo).

\section{CÓDIGO}

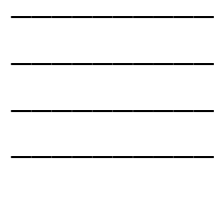

\section{GOSTO}

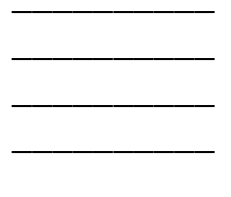

Figura 6. Modelo da ficha de reconhecimento de gostos básicos

$3^{a}$ Etapa - Teste de sensitividade para gosto: foi realizado utilizando-se o teste triangular (ASTM, 1968), para os gostos básicos: ácido e doce, com 6 repetições para cada solução. O modelo da ficha entregue aos provadores encontra-se na Figura 7. Os testes foram realizados nas mesmas condições dos testes para gostos básicos. Foram selecionados 10 provadores, os quais obtiveram a margem de acertos da análise seqüencial, com $\mathrm{p}_{0}=0,35, \mathrm{p}_{1}=0,65, \mathrm{a}=0,01$, e $\mathrm{b}=0,05$ (Wald, 1947). 
Nome:

Data:

Destas três amostras, duas são iguais e uma é diferente. Por favor, prove da esquerda para a direita com intervalo de 20 segundos entre as amostras e identifique a amostra diferente, fazendo um círculo ao redor do código.

1)

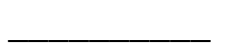

2)

3)

Figura 7. Modelo da ficha do teste de sensitividade para gosto

No teste de reconhecimento de odor foram oferecidos estímulos aromáticos colocados em béqueres de $50 \mathrm{ml}$ e recobertos com papel alumínio perfurado (Spoto, 1994).

O teste de reconhecimento de textura realizou-se segundo Civille \& Szczesniak (1973).

\subsubsection{Treinamento e desenvolvimento da terminologia descritiva (Stone, 1983).}

A fase de treinamento da Análise Descritiva Quantitativa (ADQ), constou de uma preleção aos provadores pelo supervisor, objetivando desenvolver a terminologia na identificação dos atributos sensoriais dos diferentes graus de maturação da laranja. O desenvolvimento da terminologia descritiva das amostras das laranjas foi realizado baseando-se no método tradicional (Stone et al, 1974). As amostras foram descascadas e apresentadas em pratos de porcelana, à temperatura ambiente, codificados com números de 3 algarismos. Os testes foram realizados sob Luz do dia-artificial TL-86 a 6500K. Foi solicitado aos provadores que descrevessem as características de aroma, sabor e textura, 
na ficha de levantamento de atributos. Para a aparência, foram oferecidos frutos inteiros (Figura 8).

Foram realizadas 3 sessões nessa fase, sendo posteriormente realizado o agrupamento dos termos descritivos semelhantes; os discrepantes foram eliminados, chegando-se aos termos mais apropriados, que realmente caracterizassem as amostras (Figura 9). Em seguida, foi elaborada a ficha de avaliação sensorial (Figura 10). Para a medida da intensidade de cada atributo foi usada uma escala estruturada de 1 a 9, variando de nada (nota 1), a muito (nota 9) (Silva \& Damásio, 1996).

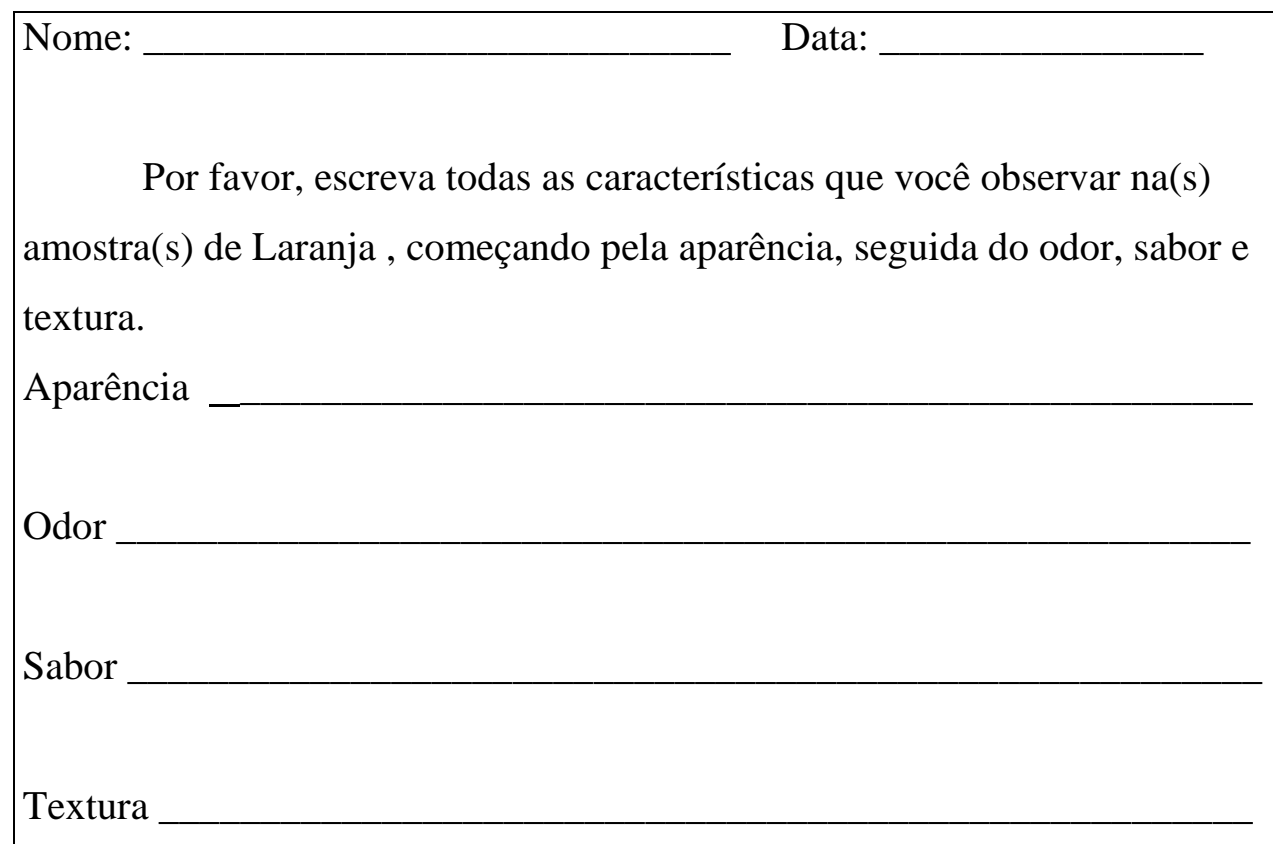

Figura 8. Modelo da ficha de levantamento de atributos

O método utilizado para desenvolver uma lista de termos descritivos foi o Método Tradicional (Moskowitz, 1983). Os termos levantados para a elaboração da ficha de avaliação são descritos na Figura 9. 


\section{APARÊNCIA}

Verde (7), esverdeada(2), amarela(4), amarelo opaco(1);

Cor pouco homogênea (2), não uniforme (5), irregular (3), desuniforme (2), uniforme (2), várias cores (1);

Fresca (2); passada (4); de verde (1); pouco madura(3); apêndices ressecados (1); apêndice envelhecido (1);

Firme (2); não firme (1); amolecida (2); murcha (2); meio murcha (5); molegata (1);

Defeitos (3); sem defeitos (1); ferrugem (2); cicatriz (2); manchas (4); perfurações (1); necrose (1);

Formato alongado (1); arredondada (1); formato uniforme (1); deformado (1);

Tamanho médio (2); tamanho pequeno (1);

Brilhante; casca fina; poucas sementes; albedo fino, lisa (6);

Pintada (1); pintadinha (1)—coloração ou defeito;

Característica; agradável; boa; satisfatória.

\section{ODOR}

Laranja (7); natural (1); cítrico (1); sumo (2); característico (4); pouco característico (1); fresca (4); refrescante (1);

Adocicado (5); doce (2); não muito doce (1);

Ácido (4); não ácido (2);

Maduro (4); fruto não maduro (1); não passado (2); laranja verde (1); começando amadurecer (1).

\section{SABOR}

Doce (9);levemente doce (4); pouco doce (4); sem doçura (1);

Ácido (8); azedinho (10); levemente ácido (3); não ácido (2);

Laranja (4); Natural (2); característico (3); cítrico (1);

Madura (3); não amadurecido (2); não passada (1); passada (2); recém-colhido (1); nem verde nem maduro (1);

Refrescante (1); fresca (5);

Amargo (1); não picante (1);

Aguado (2); aquosa (1); não aguado (1); pouco suco (1);

Agradável; saborosa.

\section{TEXTURA}

Firme (15), rija (1), tenra (1), consistente (3); não dura (1); macia (1); bagacilhos firmes (2);

Suculenta (12); pouco suculenta (3); seca (1); células intumescidas (1); aguada (1); Fibrosa (7); fluida (1); suco fino (1);

Albedo resistente e grosso; corta com facilidade; fácil mastigação; homogênea.

Figura 9. Levantamento de Termos da Laranja Pêra (Limeira-Barretos) 
Para medida de intensidade de cada tributo foi usada uma escala estruturada de 1 a 9 (Stone et al, 1974), como mostra a Figura10.

\section{Nome:}

Data:

APARÊNCIA

1. Cor Laranja

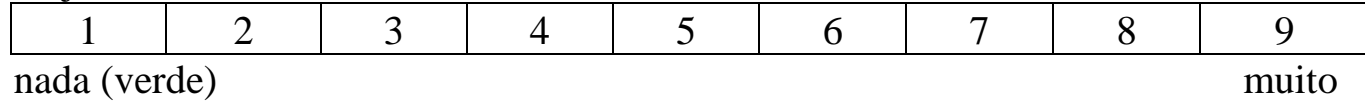

2. Uniforme

\begin{tabular}{|r|c|c|c|c|c|c|c|c|}
\hline 1 & 2 & 3 & 4 & 5 & 6 & 7 & 8 & 9 \\
\hline Nada
\end{tabular}

3. Maduro

\begin{tabular}{|c|c|c|c|c|c|c|c|c|}
\hline 1 & 2 & 3 & 4 & 5 & 6 & 7 & 8 & 9 \\
\hline nada
\end{tabular}

4. Passado

\begin{tabular}{|r|c|c|c|c|c|c|c|c|}
\hline 1 & 2 & 3 & 4 & 5 & 6 & 7 & 8 & 9 \\
\hline nada
\end{tabular}

5. Manchas e/ou Defeitos

\begin{tabular}{|c|c|c|c|c|c|c|c|c|}
\hline 1 & 2 & 3 & 4 & 5 & 6 & 7 & 8 & 9 \\
\hline nenhuma
\end{tabular}

6. Fruto Murcho

\begin{tabular}{|c|c|c|c|c|c|c|c|c|}
\hline 1 & 2 & 3 & 4 & 5 & 6 & 7 & 8 & 9 \\
\hline nada
\end{tabular}

7. Casca Lisa

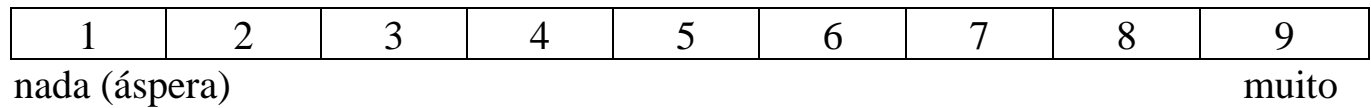

AROMA

8. Maduro

\begin{tabular}{|c|c|c|c|c|c|c|c|c|}
\hline 1 & 2 & 3 & 4 & 5 & 6 & 7 & 8 & 9 \\
\hline nada
\end{tabular}

9. Passado

\begin{tabular}{|c|c|c|c|c|c|c|c|c|}
\hline 1 & 2 & 3 & 4 & 5 & 6 & 7 & 8 & 9 \\
\hline nada
\end{tabular}

10. Ácido

\begin{tabular}{|c|c|c|c|c|c|c|c|c|}
\hline 1 & 2 & 3 & 4 & 5 & 6 & 7 & 8 & 9 \\
\hline nada
\end{tabular}

11. Doce

\begin{tabular}{|c|c|c|c|c|c|c|c|c|}
\hline 1 & 2 & 3 & 4 & 5 & 6 & 7 & 8 & 9 \\
\hline nada
\end{tabular}


SABOR

12. Laranja

\begin{tabular}{|r|c|c|c|c|c|c|c|c|}
\hline 1 & 2 & 3 & 4 & 5 & 6 & 7 & 8 & 9 \\
\hline fraco
\end{tabular}

13. Ácido

\begin{tabular}{|r|c|c|c|c|c|c|c|c|}
\hline 1 & 2 & 3 & 4 & 5 & 6 & 7 & 8 & 9 \\
\hline nada
\end{tabular}

14. Doce

\begin{tabular}{|c|c|c|c|c|c|c|c|c|}
\hline 1 & 2 & 3 & 4 & 5 & 6 & 7 & 8 & 9 \\
\hline nada
\end{tabular}

15. Maduro

\begin{tabular}{|r|c|c|c|c|c|c|c|c|}
\hline 1 & 2 & 3 & 4 & 5 & 6 & 7 & 8 & 9 \\
\hline nada
\end{tabular}

16. Passado

\begin{tabular}{|c|c|c|c|c|c|c|c|c|}
\hline 1 & 2 & 3 & 4 & 5 & 6 & 7 & 8 & 9 \\
\hline nada
\end{tabular}

TEXTURA

17. Firme

\begin{tabular}{|r|c|c|c|c|c|c|c|c|}
\hline 1 & 2 & 3 & 4 & 5 & 6 & 7 & 8 & 9 \\
\hline nada
\end{tabular}

18. Fibras

\begin{tabular}{|c|c|c|c|c|c|c|c|c|}
\hline 1 & 2 & 3 & 4 & 5 & 6 & 7 & 8 & 9 \\
\hline
\end{tabular}

19. Suculento

\begin{tabular}{|c|c|c|c|c|c|c|c|c|}
\hline 1 & 2 & 3 & 4 & 5 & 6 & 7 & 8 & 9 \\
\hline nada
\end{tabular}

Figura 10. Ficha de Análise Descritiva Quantitativa de laranja Pêra das regiões de Barretos e Limeira

Com os atributos selecionados, e a ficha de avaliação montada, foram preparadas as referências para a determinação dos extremos da escala de avaliação sensorial e treinamento dos provadores (Figura11). 


\begin{tabular}{|c|c|c|}
\hline ATRIBUTO SENSORIAL & DEFINIÇÃO & REFERÊNCIA \\
\hline \multicolumn{3}{|l|}{ APARÊNCIA } \\
\hline Cor laranja & Cor característica de laranja madura. & $\begin{array}{l}\text { Nada: laranja verde, } 8^{\circ} \mathrm{B} \text {. } \\
\text { Muito: laranja madura, }>10^{\circ} \mathrm{B} \text {. }\end{array}$ \\
\hline Uniforme & $\begin{array}{l}\text { Padronização de cor, considerando a } \\
\text { porcentagem de recobrimento no fruto }\end{array}$ & $\begin{array}{l}\text { Nada: frutos coloridos, metade } \\
\text { verdes, metade amarela } \\
\text { Muito: frutos totalmente amarelos } \\
\text { ou verdes. }\end{array}$ \\
\hline Maduro & $\begin{array}{l}\text { Característico de fruto maduro, ótimo } \\
\text { para o consumo }\end{array}$ & $\begin{array}{l}\text { Nada: laranja com } 8^{\circ} \text { Brix. } \\
\text { Muito: laranja com teor de sólidos } \\
\text { solúveis }>10^{\circ} \text { Brix. }\end{array}$ \\
\hline Passado & $\begin{array}{l}\text { Característico de fruto murcho, em } \\
\text { estado de senescência }\end{array}$ & $\begin{array}{l}\text { Nada: frutos verdes e maduros (até } \\
10^{\circ} \text { Brix) } \\
\text { Muito: frutos murchos. }\end{array}$ \\
\hline \multicolumn{3}{|l|}{ ODOR } \\
\hline Maduro & $\begin{array}{l}\text { Característico de fruto maduro, odor } \\
\text { adocicado. }\end{array}$ & $\begin{array}{l}\text { Nada: laranja verde } 8^{\circ} \mathrm{B} \text {. } \\
\text { Muito: fruto maduro } 14^{\circ} \mathrm{B} \text {. }\end{array}$ \\
\hline Passado & $\begin{array}{l}\text { Característico de fruto em estado de } \\
\text { senescência. }\end{array}$ & $\begin{array}{l}\text { Nada: frutos verdes e maduros } \\
\text { (até } 12^{\circ} \text { Brix) } \\
\text { Muito: murcho com } 3 \text { dias de } \\
\text { armazenamento }\end{array}$ \\
\hline Ácido & Característico de laranja imatura & $\begin{array}{l}\text { Nada: laranja com } 14^{\circ} \text { Brix } \\
\text { Muito: laranja com } 8^{\circ} \text { Brix }\end{array}$ \\
\hline Doce & $\begin{array}{l}\text { Característico de fruto maduro, odor } \\
\text { adocicado. }\end{array}$ & $\begin{array}{l}\text { Nada: laranja verde } 8^{\circ} \mathrm{B} \text {. } \\
\text { Muito: Lar. madura } 14^{\circ} \mathrm{B} \text {. }\end{array}$ \\
\hline \multicolumn{3}{|l|}{ SABOR } \\
\hline Laranja & Característico de fruto maduro. & $\begin{array}{l}\text { Nada: suco laranja verde } 8^{\circ} \mathrm{B} \text {. } \\
\text { Muito: suco fresco laranja madura } \\
14^{\circ} \mathrm{B} \text {. }\end{array}$ \\
\hline Ácido & $\begin{array}{l}\text { Característico de fruto verde, pré } \\
\text { maturação. }\end{array}$ & $\begin{array}{l}\text { Pouco: lar. madura }\left(14^{\circ} \mathrm{Brix}\right) \text {. } \\
\text { Muito: laranja verde } 8^{\circ} \mathrm{B} \text {. }\end{array}$ \\
\hline Doce & $\begin{array}{l}\text { Característico de fruto maduro, gosto } \\
\text { doce. }\end{array}$ & $\begin{array}{l}\text { Nada: laranja verde } 8^{\circ} \mathrm{B} \text {. } \\
\text { Muito: Lar. madura } 14^{\circ} \mathrm{B}\end{array}$ \\
\hline Maduro & Fruto maduro, ótimo para o consumo & $\begin{array}{l}\text { Nada: laranja verde } 8^{\circ} \mathrm{B} \\
\text { Muito: lar. madura } 14^{\circ} \mathrm{B} \text {. }\end{array}$ \\
\hline Passado & $\begin{array}{l}\text { Característico de fruto em estado de } \\
\text { senescência, murcho. }\end{array}$ & $\begin{array}{l}\text { Nada: frutos verdes e maduros (até } \\
15^{\circ} \text { Brix) } \\
\text { Muito: frutos murchos. } \\
\end{array}$ \\
\hline \multicolumn{3}{|l|}{ TEXTURA } \\
\hline Firme & $\begin{array}{l}\text { Textura referente ao fruto maduro, } \\
\text { suculento }\end{array}$ & \begin{tabular}{|l} 
Nada: fruto murcho \\
Muito: fruto fresco $(10 \mathrm{~N})$
\end{tabular} \\
\hline Fibras & $\begin{array}{l}\text { Característico de frutos verdes, pouca } \\
\text { suculência }\end{array}$ & $\begin{array}{l}\text { Pouca: fruto maduro } 14^{\circ} \mathrm{B} \\
\text { Muita: fruto verde }\left(8^{\circ} \mathrm{Brix}\right)\end{array}$ \\
\hline Suculento & Fruto com muito suco, túrgido, úmido. & $\begin{array}{l}\text { Nada: laranja verde, } 8^{\circ} \mathrm{B} \\
\text { Muito: lar. madura } 14^{\circ} \mathrm{B} \text {. }\end{array}$ \\
\hline
\end{tabular}

Figura 11. Definição dos descritores e referências dos extremos das escalas de intensidade na ADQ de laranja Pêra 


\subsection{Análise Estatística}

O programa estatístico empregado foi o SAS, aplicado aos dados obtidos das avaliações físico-químicas e sensoriais, com o teste F para Análise de Variância, Teste de Tukey, para identificar diferenças estatísticas entre as médias e Análise estatística multivariada para os estudos de correlação. Foi estabelecido nível de significância a 5\% de probabilidade. Para o estudo de correlação estabeleceram-se dois conjuntos de dados, físico-químicos e sensoriais, os quais foram avaliados estatisticamente pelo programa PCord (PC-ORD for Windows 95, 98, 00, ME, NT).

Sounis (1975), avalia a interdependência entre as variáveis (físico-químicas e sensoriais) onde se deve considerar o valor L (coeficiente de correlação), maior que 0,7. Este varia no intervalo de -1 e +1 e indica o máximo de correlação. Os sinais - e + mostram o sentido da correlação e o valor zero indica ausência de correlação ou independência entre as variáveis.

\subsection{Identificação das necessidades dos clientes}

Consideram-se como público alvo os compradores de laranja que efetivamente compravam laranja no momento da entrevista, atendendo à indicação de ASTM; Damásio \& Silva; Meilgaard et al., por Ferreira et al. (2000).

Foram realizadas entrevistas individuais com 35 clientes em cada local da pesquisa, conforme número indicado por Cheng et al. (1995), no momento da compra, ou seja, quando se encontravam na banca de laranja, não se privilegiando quaisquer grupos de consumidores realizada no Mercado Municipal de Piracicaba e no Supermercado Pão de Açúcar (Centro-Piracicaba).

Para tanto, foi formulado um questionário que melhor sintetizou as informações necessárias e incentivou os consumidores a enumerarem características interessantes que gostariam que a fruta tivesse, e características não desejáveis. 
QUESTIONÁRIO QUALITATIVO (Método QFD)

Questionário $n^{\circ}$

Data: / 2004

Local: ( ) Mercado Municipal de Piracicaba ( ) Supermercado Pão de Açúcar (Centro) Nome: Sexo: M( ) F( )

Idade: Profissão:

Escolaridade: Estado Civil:

Tem Filho: Sim ( ) Não ( ) Renda Familiar:

Que variedades de laranja Pêra você conhece e quais as suas características?

Qual o destino da laranja Pêra que você compra? (suco, doce, consumo in natura, etc).

O que você observa na laranja na hora de comprar?

O que você espera da laranja Pêra in natura?

Em sua opinião, qual seria a laranja Pêra ideal?

Quais problemas você já teve com laranja Pêra?

Figura 12. Questionário utilizado para a realização da Avaliação Qualitativa no Mercado Municipal de Piracicaba (Mercadão) e no Supermercado Pão de Açúcar (Centro) 


\section{RESULTADOS E DISCUSSÃO}

Os dados obtidos das análises físico-químicas e sensoriais foram submetidos ao procedimento estatístico de Análise de Variância, Teste de Médias (Tukey $\alpha=0,05$ ) e Correlação. Os resultados obtidos são apresentados nas Tabelas 1 a 9.

\subsection{Análises físico-químicas}

Através dos resultados obtidos (Tabela 1), pode-se observar que todos os parâmetros, peso, volume, densidade e diâmetro dos frutos oriundos de Barretos apresentaram variação estatística entre as colorações C1 e C2 e a coloração C3, correspondente a 90\% amarela, segundo o "Programa Brasileiro para a Melhoria dos Padrões Comerciais e Embalagens Hortigranjeiros" (CEAGESP, 2000), sendo que para o diâmetro, não houve variação entre C2 e C3.

Para os frutos provenientes de Limeira, os parâmetros peso, volume e densidade não apresentaram diferenças significativas $(\alpha=0,05)$ entre todas as colorações, sendo que apenas o diâmetro variou entre as colorações C2 e C3 e a coloração C4. 
Tabela 1. Valores médios de peso, volume, densidade e diâmetro de laranjas com coloração C1, C2 e C3 da região de Barretos e C2, C3 e C4 da região de Limeira

\begin{tabular}{cccccccccc}
\hline \multicolumn{4}{c}{ Região de Barretos } & \multicolumn{8}{c}{ Região de Limeira } \\
\hline & $\begin{array}{c}\text { Peso } \\
\text { (g) }\end{array}$ & $\begin{array}{c}\text { Volume } \\
(\mathrm{ml})\end{array}$ & $\begin{array}{c}\text { Densidade } \\
(\mathrm{g} / \mathrm{ml})\end{array}$ & $\begin{array}{c}\text { Diâmetro } \\
(\mathrm{cm})\end{array}$ & & $\begin{array}{c}\text { Peso } \\
(\mathrm{g})\end{array}$ & $\begin{array}{c}\text { Volume } \\
(\mathrm{ml})\end{array}$ & $\begin{array}{c}\text { Densidade } \\
(\mathrm{g} / \mathrm{ml})\end{array}$ & $\begin{array}{c}\text { Diâmetro } \\
(\mathrm{cm})\end{array}$ \\
$\mathrm{C} 1$ & $189,21 \mathrm{a}$ & $190,43 \mathrm{a}$ & $0,99 \mathrm{a}$ & $67,40 \mathrm{a}$ & $\mathrm{C} 2$ & $227,70 \mathrm{a}$ & $231,46 \mathrm{a}$ & $0,98 \mathrm{a}$ & $71,8 \mathrm{a}$ \\
$\mathrm{C} 2$ & $183,30 \mathrm{a}$ & $186,47 \mathrm{a}$ & $0,98 \mathrm{a}$ & $64,10 \mathrm{~b}$ & $\mathrm{C} 3$ & $221,33 \mathrm{a}$ & $227,92 \mathrm{a}$ & $0,98 \mathrm{a}$ & $72,50 \mathrm{a}$ \\
$\mathrm{C} 3$ & $164,98 \mathrm{~b}$ & $170,32 \mathrm{~b}$ & $0,96 \mathrm{~b}$ & $63,70 \mathrm{~b}$ & $\mathrm{C} 4$ & $209,79 \mathrm{a}$ & $215,96 \mathrm{a}$ & $0,97 \mathrm{a}$ & $70,90 \mathrm{~b}$ \\
Valor F & $66,41^{*}$ & $59,92^{*}$ & $6,27^{*}$ & $55,16^{*}$ & Valor F & $1,97 \mathrm{~ns}$ & $1,42 \mathrm{~ns}$ & $0,90 \mathrm{~ns}$ & $2,76^{*}$ \\
Pr $>\mathrm{F}$ & $<0,0001$ & $<0,0001$ & 0,0022 & $<0,0001$ & Pr $>\mathrm{F}$ & 0,1439 & 0,2446 & 0,4076 & 0,0066 \\
& & & & & & & & & \\
\hline
\end{tabular}

* Médias seguidas da mesma letra nas colunas não diferem entre si a $\alpha=0,05$.

Segundo o "Programa Brasileiro..." (CEAGESP, 2000) (Figura 1), a classe (calibre) é relacionada ao tamanho dos frutos medido pelo seu diâmetro equatorial. Pelo presente trabalho, para as laranjas de Barretos, apenas a $\mathrm{C} 1$ se apresentou na classe 66 (diâmetro de 66 a $68 \mathrm{~mm}$ ), as demais colorações C2 e C3, se apresentaram na classe 63 (diâmetro de 63 a $66 \mathrm{~mm}$ ). Com isso, pode-se concluir que, durante o amadurecimento do fruto na planta, pode ter ocorrido perda de umidade, com redução do seu tamanho, pois na coloração $\mathrm{C} 1$, o fruto já se apresentava com o máximo de crescimento, ocorrendo apenas a fase de amadurecimento nas demais colorações. Tal fato pode ser observado na redução dos demais parâmetros, embora menos sensivelmente, apenas entre C2 e C3 (Tabela 1).

Para as laranjas de Limeira verificou-se que as colorações C2 e C4 encontraramse na classe 68 (68 a $72 \mathrm{~mm}$ ), conforme o "Programa Brasileiro..." (CEAGESP, 2000). Apenas a coloração C3 apresentou-se na classe 72 (72 a 75 mm). Mesmo não havendo diferença significativa para peso, volume e densidade notam-se um decréscimo nos valores de $\mathrm{C} 2$ para $\mathrm{C} 4$, explicado pela desidratação do fruto, como observado nas laranjas de Barretos. 
Avaliando-se os parâmetros físicos de cor e resistência da casca na Tabela 2, pode-se observar que a resistência não apresentou alterações estatísticas entre os padrões de coloração C1, C2 e C3 de Barretos, fato interessante, pois se esperava que a C1 fosse mais resistente do que a $\mathrm{C} 3$, por apresentar-se mais verde. Geralmente, à medida que os frutos vão amadurecendo, estes vão perdendo a firmeza devido à solubilização da protopectina e transformação em pectina na forma solúvel através da ação de enzimas (Proctor et al., 1985) (Tabela 2).

Ainda segundo a Tabela 2, observou-se que, para as laranjas provenientes de Limeira, a resistência apresentou alterações significativas, diferentes das esperadas, uma vez que esta aumentou com o amadurecimento da fruta. Uma possível justificativa para tal fato seria a solubilização da protopectina das paredes celulares liberando cálcio, tornando o albedo mais elástico e consequentemente dificultando a penetração da região de inserção do aparelho nas análises físicas.

A firmeza de produtos hortícolas pode ser medida pela compressão com diferentes sondas de diferentes forças ou níveis de deformação. $O$ aparelho que foi utilizado, o penetrômetro, mede objetivamente o grau de maturação para a colheita, e são bem correlacionados com a percepção humana da firmeza, mas somente esse parâmetro não deve ser utilizado como padrão de textura dos frutos, pois a firmeza é somente um dos grupos de propriedades que definem a textura (Abbott, 1999). 
Tabela 2. Valores médios de cor $\left(\mathrm{L}, \mathrm{a}^{*}, \mathrm{~b}^{*}\right)$ e resistência de laranjas com coloração $\mathrm{C} 1$, $\mathrm{C} 2$ e C3 da região de Barretos e C2, C3 e C4 da região de Limeira

\begin{tabular}{|c|c|c|c|c|c|c|c|c|c|}
\hline \multicolumn{6}{|c|}{ Região de Barretos } & \multicolumn{4}{|c|}{ Região de Limeira } \\
\hline & $\overline{\mathrm{L}}$ & $\mathrm{a}$ & $\mathrm{b}$ & $\begin{array}{l}\text { Resistência } \\
(\mathrm{kg})\end{array}$ & & $\mathrm{L}$ & $\mathrm{a}$ & $\mathrm{b}$ & $\begin{array}{c}\text { Resistência } \\
(\mathrm{kg})\end{array}$ \\
\hline $\mathrm{C} 1$ & $54,19 b$ & $-16,20 c$ & $42,09 b$ & $17,72 \mathrm{a}$ & $\mathrm{C} 2$ & $60,05 b$ & $-3,90 b$ & $51,48 b$ & $14,16 b$ \\
\hline $\mathrm{C} 2$ & $61,79 \mathrm{a}$ & $-5,60 \mathrm{~b}$ & $53,96 a$ & $16,96 a$ & $\mathrm{C} 3$ & $63.91 \mathrm{a}$ & $3,35 \mathrm{a}$ & $56,44 a$ & $15,58 \mathrm{ab}$ \\
\hline $\mathrm{C} 3$ & $62,18 \mathrm{a}$ & $0,40 \mathrm{a}$ & $54,13 \mathrm{a}$ & $17,73 \mathrm{a}$ & $\mathrm{C} 4$ & $64,52 \mathrm{a}$ & $4,85 \mathrm{a}$ & $58,50 \mathrm{a}$ & $17,78^{\mathrm{a}}$ \\
\hline Valor F & $17,77^{*}$ & $23,69 *$ & $17,24 *$ & $0,34 \mathrm{n} \cdot \mathrm{s}$ & Valor F & $19,88^{*}$ & $100,64 *$ & $21,34 *$ & $8,12 *$ \\
\hline $\operatorname{Pr}>\mathrm{F}$ & $<0,0001$ & $<0,0001$ & $<0,0001$ & 0,7125 & $\operatorname{Pr}>\mathrm{F}$ & $<0,0001$ & $<0,0001$ & $<0,0001$ & 0,0007 \\
\hline
\end{tabular}

* Médias seguidas da mesma letra nas colunas não diferem entre si a $\alpha=0,05$.

Os valores $\mathrm{a}^{*} \mathrm{e} \mathrm{b}^{*}$ indicam o croma, ou seja, a cor do fruto. $\mathrm{O}$ valor $\mathrm{a}^{*}$ caracteriza coloração na região do vermelho $\left(+a^{*}\right)$ ao verde $\left(-a^{*}\right)$, o valor $b^{*}$ indica coloração no intervalo do amarelo $\left(+b^{*}\right)$ ao azul $\left(-b^{*}\right)$. O valor $L$ indica a luminosidade, variando do branco $(\mathrm{L}=100)$ ao preto $(\mathrm{L}=0)$. Todos os valores apresentaram variações estatísticas, como o esperado, ou seja, à medida que o fruto amadurece, as colorações se alteram, com os valores a e b se elevando mais para a região do amarelo, embora ainda permaneçam no $4^{\circ}$ quadrante da escala de cores (Tabela 2 ).

As alterações na coloração durante o amadurecimento são correlacionadas pelo consumidor, com o aumento da doçura e com o desenvolvimento de outros atributos desejáveis. Mas, nem sempre há uma correlação entre cor e qualidade, como a laranja que às vezes se apresenta verde e se encontra comercialmente madura em algumas situações, em função das condições climáticas, região de cultivo e época do ano (Chitarra \& Chitarra, 1990).

As análises físico-químicas de teor de sólidos solúveis (TSS), ratio, $\mathrm{pH}$, acidez e vitamina $\mathrm{C}$ apresentaram alterações significativas com as colorações $\mathrm{C} 1, \mathrm{C} 2$ e $\mathrm{C} 3$ de Barretos, sendo que, o teor de sólidos solúveis e a acidez apresentaram diferenças entre a $\mathrm{C} 1$ e as demais ( $\mathrm{C} 2$ e $\mathrm{C} 3$ ), enquanto que, para o ratio, $\mathrm{pH}$ e vitamina $\mathrm{C}$, somente a $\mathrm{C} 3$ variou em relação às demais. Assim, pode-se concluir que as laranjas da coloração C3 
possivelmente encontravam-se mais maduras e mais doces em relação às demais, e também com valores significativamente mais elevados de vitamina $\mathrm{C}$ em relação às outras colorações (Tabela 3).

Para as laranjas provenientes de Limeira não houve diferença significativa nos teores de sólidos solúveis, ratio e acidez. Houve variação para os valores de pH entre as colorações $\mathrm{C} 2$ e $\mathrm{C} 4$, que se relacionam com a redução da acidez conforme o amadurecimento do fruto. O teor de Vitamina C também apresentou diferença significativa entre $\mathrm{C} 2$ e $\mathrm{C} 3$, fato esperado, pois à medida que o fruto amadurece, alguns compostos orgânicos são transformados em ácidos com o processo respiratório.Os teores de acidez, em geral, não excedem 1,5 a 2,0\%, com raras exceções, como o limão, maracujá e espinafre que podem conter teores acima de 3\%. Em laranjas Lima a acidez é cerca de 10 vezes inferior à das laranjas comuns (Pêra, Valência etc.)

A relação sólidos solúveis / acidez titulável é também um critério de avaliação do sabor da fruta, podendo representar o seu grau de maturação. Testes feitos através da análise sensorial, demonstram que a relação deve ser de 10:1 em laranjas e de 9:1 em tangerinas, desde que o conteúdo de sólidos solúveis seja igual a 9\%. Se o teor de sólidos solúveis for baixo, é necessária uma relação mais elevada, para obtenção de um sabor aceitável. A relação aumenta com o amadurecimento devido ao decréscimo na acidez, fato que permite uma relação elevada, em frutos contendo baixo teor de sólidos solúveis. Do mesmo modo, frutos com teor de sólidos solúveis superior a $9 \%$, podem apresentar relação menor que 10:1, ou seja, laranjas com 11\% de sólidos solúveis podem apresentar relação de 9:1, adequada ao paladar do consumidor (Chitarra \& Chitarra, 1990). 
Tabela 3. Valores médios de teor de sólidos solúveis (TSS), ratio, pH, acidez e vitamina C de laranjas com coloração $\mathrm{C} 1, \mathrm{C} 2$ e C3 da região de Barretos e C2, C3 e C4 da região de Limeira

\begin{tabular}{cccccc}
\hline \multicolumn{7}{c}{ Região de Barretos } \\
& $\begin{array}{c}\text { TSS } \\
\left({ }^{\circ} \text { Brix }\right)\end{array}$ & Ratio & $\mathrm{pH}$ & $\begin{array}{c}\text { Acidez } \\
(\text { ATT })\end{array}$ & $\begin{array}{c}\text { Vitamina C } \\
(\%)\end{array}$ \\
\hline $\mathrm{C} 1$ & $10,23 \mathrm{~b}$ & $12,59 \mathrm{~b}$ & $3,56 \mathrm{~b}$ & $0,81 \mathrm{a}$ & $12,95 \mathrm{~b}$ \\
$\mathrm{C} 2$ & $11,68 \mathrm{a}$ & $17,16 \mathrm{~b}$ & $3,61 \mathrm{~b}$ & $0,45 \mathrm{~b}$ & $30,62 \mathrm{~b}$ \\
$\mathrm{C} 3$ & $11,58 \mathrm{a}$ & $22,12 \mathrm{a}$ & $3,91 \mathrm{a}$ & $0,47 \mathrm{~b}$ & $46,31 \mathrm{a}$ \\
Valor F & $4,45^{*}$ & $10,65^{*}$ & $6,66^{*}$ & $3,78^{*}$ & $11,30^{*}$ \\
Pr>F & 0,0288 & 0,0013 & 0,009 & 0,047 & 0,001 \\
\hline $\mathrm{C} 2$ & & Região de Limeira & & $48,19 \mathrm{~b}$ \\
$\mathrm{C} 3$ & $9,57 \mathrm{a}$ & $14,85 \mathrm{a}$ & $3,72 \mathrm{~b}$ & $0,65 \mathrm{a}$ & $61,71 \mathrm{a}$ \\
$\mathrm{C} 4$ & $9,42 \mathrm{a}$ & $15,60 \mathrm{a}$ & $3,81 \mathrm{ab}$ & $0,61 \mathrm{a}$ & $58,29 \mathrm{ab}$ \\
Valor F & $9,62 \mathrm{a}$ & $15,91 \mathrm{a}$ & $3,84 \mathrm{a}$ & $0,60 \mathrm{a}$ & $5,05^{*}$ \\
Pr>F & $0,28 \mathrm{~ns}$ & $1,69 \mathrm{~ns}$ & $5,01^{*}$ & $1,64 \mathrm{~ns}$ & 0,0211 \\
\hline
\end{tabular}

*Médias seguidas da mesma letra nas colunas não diferem entre si a $\alpha=0,05$.

Os dados de clorofila, carotenóides, e compostos fenólicos dos frutos de Barretos não apresentaram variações entre as colorações.

Os valores de açúcar redutor e total apresentaram aumento com o decorrer da coloração, ratificando os resultados do teor de sólidos solúveis, acidez e ratio (Tabelas 3 e 4).

Os frutos provenientes de Limeira apresentaram variação significativa nos teores de carotenóides, fato esperado, pois à medida que amadurece, ocorre a síntese desses pigmentos.

Segundo Oliva (2002), o ratio menor que 12 abrange frutas não maduras e abaixo de 13, os frutos nessa faixa apresentam baixa aceitação pelo consumidor. Viegas (1991) em suas análises, caracteriza as amostras com maior aceitação sensorial de ratio entre 15 e 18 .

Uma importante parte do gosto apresentado por muitos frutos é a mistura atribuída ao sabor doce e ácido. A proporção açúcar/ácido pode ser acompanhada 
naturalmente, permitindo que os frutos amadureçam até o ponto onde os açúcares têm aumentado e os ácidos reduzidos para a proporção desejável. Os frutos podem tornar-se sobremaduros do ponto de vista de sabor tanto pelo acúmulo de açúcares quanto pela perda de acidez e se apresentarem poucos saborosos. Há diferenças nas proporções açúcar/ácido entre variedades do mesmo produto e mesmo dentro da própria variedade cultivada em diferentes condições (Calore \& Vieites, 2003).

As substâncias pécticas são os principais componentes químicos dos tecidos, responsáveis pelas mudanças de textura dos frutos e hortaliças (Chitarra \& Chitarra, 1990). Com o amadurecimento ocorre a solubilização da protopectina das paredes celulares e formação de pectina solúvel, como pode ser observado na Tabela 4, com o decréscimo dos teores de pectina total e aumento de pectina solúvel (Proctor et al., 1985). 
Tabela 4. Valores médios de clorofila, carotenóides, açúcar total, açúcar redutor, compostos fenólicos e pectina total e solúvel de laranjas com coloração $\mathrm{C} 1$, C2 e C3 da região de Barretos e C2, C3 e C4 da região de Limeira

\begin{tabular}{|c|c|c|c|c|c|c|c|}
\hline \multicolumn{8}{|c|}{ Região de Barretos } \\
\hline & $\begin{array}{c}\text { Clorofila } \\
\text { (mg \%) }\end{array}$ & $\begin{array}{c}\text { Carotenóides } \\
(\mathrm{mg} \%)\end{array}$ & $\begin{array}{c}\text { Açúcar total } \\
(\%)\end{array}$ & $\begin{array}{c}\text { Açúcar redutor } \\
(\%)\end{array}$ & $\begin{array}{c}\text { Fenólicos } \\
\text { (mEq ác. } \\
\text { tânico/0,5ml) }\end{array}$ & $\begin{array}{l}\text { Pectina Total } \\
\text { (mg ácido. } \\
\text { galacturônico/ } \\
100 \text { g suco) }\end{array}$ & $\begin{array}{l}\text { Pectina Sol. } \\
\text { (mg ácido. } \\
\text { galacturônico/ } \\
100 \text { g suco) }\end{array}$ \\
\hline $\mathrm{C} 1$ & $15,60 \mathrm{a}$ & $3,48 \mathrm{a}$ & $23,26 b$ & $2,93 b$ & $0,02 \mathrm{a}$ & $336,57 \mathrm{a}$ & $30,39 b$ \\
\hline $\mathrm{C} 2$ & $18,82 \mathrm{a}$ & $4,11 \mathrm{a}$ & $22,73 b$ & $2,30 \mathrm{~b}$ & $0,35 \mathrm{a}$ & $187,83 b$ & $27,78 b$ \\
\hline $\mathrm{C} 3$ & $7,49 a$ & $3,64 \mathrm{a}$ & $22,29 a$ & $3,81 \mathrm{a}$ & $0,07 \mathrm{a}$ & $194,17 b$ & $67,88 \mathrm{a}$ \\
\hline Valor F & $1,13 \mathrm{~ns}$ & $0,06 \mathrm{~ns}$ & $46,12 *$ & $27,29 *$ & $0,79 \mathrm{~ns}$ & $7,39 *$ & $7,77^{*}$ \\
\hline $\operatorname{Pr}>\mathrm{F}$ & 0,3500 & 0,9400 & 0,0001 & 0,0001 & 0,4700 & 0,0019 & 0,0017 \\
\hline \multicolumn{8}{|c|}{ Região de Limeira } \\
\hline $\mathrm{C} 2$ & $7,96 a$ & $2,16 a b$ & $24,87 \mathrm{a}$ & $1,58 \mathrm{a}$ & $0,07 \mathrm{a}$ & $339,23 a$ & $64,40 \mathrm{~b}$ \\
\hline $\mathrm{C} 3$ & $8,92 \mathrm{a}$ & $1,04 b$ & $20,01 \mathrm{a}$ & $1,43 \mathrm{a}$ & $0,06 \mathrm{a}$ & $189,01 b$ & $49,33 b$ \\
\hline $\mathrm{C} 4$ & $6,14 \mathrm{a}$ & $3,33 a$ & $22,54 \mathrm{a}$ & $1,18 \mathrm{a}$ & $0,06 \mathrm{a}$ & $233,69 b$ & $106,31 \mathrm{a}$ \\
\hline Valor F & $1,26 \mathrm{~ns}$ & $7,90 *$ & $1,82 \mathrm{~ns}$ & $1,28 \mathrm{~ns}$ & $0,32 \mathrm{~ns}$ & $24,68^{*}$ & $14,41^{*}$ \\
\hline $\operatorname{Pr}>F$ & 0,3116 & 0,0045 & 0,2000 & 0,3096 & 0,7302 & $<0.0001$ & $<0.0001$ \\
\hline
\end{tabular}

* Médias seguidas da mesma letra nas colunas não diferem entre si a $\alpha=0,05$.

\subsection{Análise sensorial}

Os frutos foram submetidos à análise sensorial. Os resultados apresentam-se nas Tabelas 5, 6, 7 e 8 .

Para a aparência dos frutos de Barretos, os atributos não apresentaram diferenças estatísticas, embora possa ser observado aumento do atributo "cor laranja" com o aumento da coloração, o mesmo ocorrendo com os atributos "manchas e defeitos". Para o atributo "uniforme", houve um decréscimo devido ao aumento da pigmentação laranja, resultando em frutos mais manchados (Tabela 5). 
Os frutos provenientes de Limeira apresentaram diferenças significativas para "cor laranja", "uniforme", "maduro", "passado" e "fruto murcho". Todos esses atributos tiveram seus valores aumentados, indicando o amadurecimento do fruto com possível senescência nas laranjas de coloração C4.

Tabela 5. Valores médios para atributos de aparência de laranjas com coloração $\mathrm{C} 1, \mathrm{C} 2$ e C3 da região de Barretos e C2, C3 e C4 da região de Limeira

\begin{tabular}{|c|c|c|c|c|c|c|c|}
\hline \multicolumn{8}{|c|}{ Região de Barretos } \\
\hline & Cor laranja & Uniforme & Maduro & Passado & Manchas/defeitos & Fruto murcho & Casca lisa \\
\hline $\mathrm{C} 1$ & $2,67 \mathrm{a}$ & $4,11 \mathrm{a}$ & $2,00 \mathrm{a}$ & $0,33 \mathrm{a}$ & $2,67 \mathrm{a}$ & $1,33 \mathrm{a}$ & $4,67 \mathrm{a}$ \\
\hline $\mathrm{C} 2$ & $3,50 \mathrm{a}$ & $3,33 \mathrm{a}$ & $4,50 \mathrm{a}$ & $0,67 \mathrm{a}$ & $3,83 \mathrm{a}$ & $1,67 \mathrm{a}$ & $5,67 \mathrm{a}$ \\
\hline $\mathrm{C} 3$ & $3,75 \mathrm{a}$ & $2,75 \mathrm{a}$ & $2,56 a$ & $0,25 \mathrm{a}$ & $4,50 \mathrm{a}$ & $1,25 \mathrm{a}$ & $4,00 \mathrm{a}$ \\
\hline Valor F & $1,08 \mathrm{~ns}$ & $2,40 \mathrm{~ns}$ & $2,43 \mathrm{~ns}$ & $1,21 \mathrm{~ns}$ & $2,00 \mathrm{~ns}$ & $1,51 \mathrm{~ns}$ & $0,36 \mathrm{~ns}$ \\
\hline $\operatorname{Pr}>F$ & 0,3500 & 0,1100 & 0,1000 & 0,3100 & 0,1500 & 0,2400 & 0,7000 \\
\hline \multicolumn{8}{|c|}{ Região de Limeira } \\
\hline $\mathrm{C} 2$ & $3,40 \mathrm{~b}$ & $1,85 b$ & $3,00 \mathrm{c}$ & $0,85 \mathrm{c}$ & $4,95 \mathrm{a}$ & $1,10 \mathrm{~b}$ & $3,25 \mathrm{a}$ \\
\hline $\mathrm{C} 3$ & $5,05 \mathrm{a}$ & $3,85 \mathrm{a}$ & $5,10 \mathrm{~b}$ & $2,0 \mathrm{~b}$ & $4,40 \mathrm{a}$ & $2,25 \mathrm{ab}$ & $3,45 \mathrm{a}$ \\
\hline $\mathrm{C} 4$ & $5,40 \mathrm{a}$ & $4,05 \mathrm{a}$ & $6,50 \mathrm{a}$ & $3,65 \mathrm{a}$ & $5,65 \mathrm{a}$ & $3,30 \mathrm{a}$ & $2,85 \mathrm{a}$ \\
\hline Valor F & $6,75^{*}$ & $10,04 *$ & $24,1 *$ & $7,81 *$ & $1,73 \mathrm{~ns}$ & $5,47 *$ & $0,49 \mathrm{~ns}$ \\
\hline $\operatorname{Pr}>\mathrm{F}$ & 0,0023 & 0,0002 & $<0,0001$ & 0,0010 & 0,1861 & 0,0100 & 0,6180 \\
\hline
\end{tabular}

* Médias seguidas da mesma letra nas colunas não diferem entre si a $\alpha=0,05$.

Em relação ao aroma, para as laranjas que vieram da região de Barretos, embora estatisticamente não haja diferença significativa entre os frutos, os atributos "maduro" e "passado" apresentaram um acréscimo nos valores conforme o aumento da coloração. O “ácido" apresentou um decréscimo com a coloração, com diferença significativa entre o C3 e as demais colorações, conforme o esperado. O inverso ocorreu com o atributo de aroma "doce", o qual apresentou aumento nas colorações C2 e C3, em relação à C1. Tal fato demonstra que o fruto de coloração $\mathrm{C} 1$, ainda se apresentava verde, corroborando os dados das análises físico-químicas (Tabela 6).

Com relação aos frutos analisados da região de Limeira, não houve diferença significativa para os atributos de aroma "maduro", "passado", "ácido" e "doce". No entanto, pode-se observar que os valores de "passado" e "doce" aumentaram da classe 
C2 para $\mathrm{C} 4$, indicando que a coloração $\mathrm{C} 4$ possivelmente já se encontrava em senescência.

Tabela 6. Valores médios para atributos de aroma de laranjas C1, C2 e C3 da região de Barretos e C2, C3 e C4 da região de Limeira

\begin{tabular}{cccccccccc}
\hline \multicolumn{4}{c}{ Região de Barretos } \\
\hline & Maduro & Passado & Ácido & Doce & & Maduro & Passado & Ácido & Doce \\
\hline $\mathrm{C} 1$ & $4,11 \mathrm{a}$ & $0,22 \mathrm{a}$ & $4,67 \mathrm{a}$ & $3,11 \mathrm{a}$ & $\mathrm{C} 2$ & $5,00 \mathrm{a}$ & $0,80 \mathrm{a}$ & $3,55 \mathrm{a}$ & $2,85 \mathrm{a}$ \\
$\mathrm{C} 2$ & $4,89 \mathrm{a}$ & $0,33 \mathrm{a}$ & $3,44 \mathrm{a}$ & $4,22 \mathrm{a}$ & $\mathrm{C} 3$ & $5,15 \mathrm{a}$ & $0,90 \mathrm{a}$ & $2,90 \mathrm{a}$ & $3,90 \mathrm{a}$ \\
$\mathrm{C} 3$ & $5,19 \mathrm{a}$ & $1,31 \mathrm{a}$ & $2,13 \mathrm{~b}$ & $4,06 \mathrm{a}$ & $\mathrm{C} 4$ & $4,95 \mathrm{a}$ & $1,45 \mathrm{a}$ & $3,15 \mathrm{a}$ & $4,05 \mathrm{a}$ \\
Valor F & $0,76 \mathrm{~ns}$ & $2,57 \mathrm{~ns}$ & $3,30 *$ & $0,73 \mathrm{~ns}$ & Valor F & $0,08 \mathrm{~ns}$ & $1,07 \mathrm{~ns}$ & $0,47 \mathrm{~ns}$ & $2,78 \mathrm{~ns}$ \\
$\mathrm{Pr}>\mathrm{F}$ & 0,4800 & 0,0900 & 0,0500 & 0,4900 & Pr $>\mathrm{F}$ & 0,9273 & 0,3482 & 0,6258 & 0,0705 \\
\hline
\end{tabular}

* Médias seguidas da mesma letra nas colunas não diferem entre si a $\alpha=0,05$.

Em relação à textura, não houve variação estatística para nenhum atributo, somente "fibras" apresentou ligeiro acréscimo para a coloração C3 dos frutos de Barretos e para C4 dos frutos de Limeira (Tabela 7).

Tabela 7. Valores médios para atributos de textura de laranjas com coloração C1, C2 e C3 da região de Barretos e C2, C3 e C4 da região de Limeira

\begin{tabular}{cccccccc}
\hline \multicolumn{3}{c}{ Região de Barretos } & \multicolumn{5}{c}{ Região de Limeira } \\
\hline & Firme & Fibras & Suculento & & Firme & Fibras & Suculento \\
\hline $\mathrm{C} 1$ & $6,33 \mathrm{a}$ & $5,67 \mathrm{a}$ & $6,33 \mathrm{a}$ & $\mathrm{C} 2$ & $5,55 \mathrm{a}$ & $5,75 \mathrm{a}$ & $6,40 \mathrm{a}$ \\
$\mathrm{C} 2$ & $6,22 \mathrm{a}$ & $6,22 \mathrm{a}$ & $5,78 \mathrm{a}$ & $\mathrm{C} 3$ & $5,35 \mathrm{a}$ & $5,85 \mathrm{a}$ & $5,90 \mathrm{a}$ \\
$\mathrm{C} 3$ & $6,13 \mathrm{a}$ & $7,00 \mathrm{a}$ & $6,44 \mathrm{a}$ & $\mathrm{C} 4$ & $5,00 \mathrm{a}$ & $6,15 \mathrm{a}$ & $6,35 \mathrm{a}$ \\
Valor F & $0,05 \mathrm{~ns}$ & $2,73 \mathrm{~ns}$ & $0,42 \mathrm{~ns}$ & Valor F & $0,38 \mathrm{~ns}$ & $0,28 \mathrm{~ns}$ & $0,6 \mathrm{~ns}$ \\
$\mathrm{Pr}>\mathrm{F}$ & 0,9500 & 0,0800 & 0,6600 & Pr $>\mathrm{F}$ & 0,6867 & 0,7597 & 0,5501 \\
\hline
\end{tabular}

* Médias seguidas da mesma letra nas colunas não diferem entre si a $\alpha=0,05$.

Os atributos de sabor, de maneira análoga aos atributos de textura, não apresentaram variações estatísticas para as colorações da região de Barretos. Entretanto, pode-se observar o decréscimo no "ácido" e aumento no "doce", "maduro" e "passado". 
O sabor corresponde à percepção da combinação entre a doçura, acidez e adstringência, em conjunto com a percepção do aroma, devido à presença de compostos voláteis. $\mathrm{O}$ amadurecimento, em geral, conduz a um aumento na doçura devido ao teor de açúcares simples, decréscimo da acidez e da adstringência. Os principais compostos químicos responsáveis pelo sabor dos frutos e hortaliças são os açúcares, ácidos orgânicos e compostos fenólicos (Matoo et al., 1975).

Conclui-se, portanto, partindo dessa região onde os frutos não desverdecem, que todas as colorações podem ser utilizadas para comercialização, sendo o $\mathrm{C} 1$, no limite de aceitabilidade para o fruto verde e o $\mathrm{C} 3$, o limite para o fruto maduro (Tabela 8).

Em relação aos frutos provenientes de Limeira, observa-se que os atributos "ácido" e "doce" apresentaram variação significativa, sendo que os valores do "ácido" diminuíram da coloração $\mathrm{C} 2$ para $\mathrm{C} 3$, indicando o amadurecimento do fruto $\mathrm{e}$ confirmando os dados das análises químicas. O "doce" aumentou de C2 para C3, também indicando amadurecimento.

Tabela 8. Valores médios para atributos de sabor de laranjas com coloração C1, C2 e C3 da região de Barretos e $\mathrm{C} 2, \mathrm{C} 3$ e $\mathrm{C} 4$ da região de Limeira

\begin{tabular}{cccccc}
\hline \multicolumn{7}{c}{ Região de Barretos } \\
\hline Laranja & Ácido & Doce & Maduro & Passado \\
\hline $\mathrm{C} 1$ & $6,22 \mathrm{a}$ & $3,89 \mathrm{a}$ & $3,78 \mathrm{a}$ & $5,11 \mathrm{a}$ & $0,22 \mathrm{a}$ \\
$\mathrm{C} 2$ & $6,00 \mathrm{a}$ & $3,67 \mathrm{a}$ & $4,67 \mathrm{a}$ & $5,44 \mathrm{a}$ & $0,78 \mathrm{a}$ \\
$\mathrm{C} 3$ & $6,31 \mathrm{a}$ & $2,81 \mathrm{a}$ & $5,00 \mathrm{a}$ & $6,19 \mathrm{a}$ & $1,94 \mathrm{a}$ \\
Valor F & $0,17 \mathrm{~ns}$ & $0.89 \mathrm{~ns}$ & $1,13 \mathrm{~ns}$ & $1,3 \mathrm{~ns}$ & $1,88 \mathrm{~ns}$ \\
Pr $>\mathrm{F}$ & 0,8400 & 0,4200 & 0,3400 & 0,2900 & 0,1700 \\
\hline \multicolumn{7}{c}{ Região de Limeira } \\
\hline $\mathrm{C} 2$ & $5,10 \mathrm{a}$ & $3,75 \mathrm{a}$ & $2,95 \mathrm{~b}$ & $5,15 \mathrm{a}$ & $0,80 \mathrm{a}$ \\
$\mathrm{C} 3$ & $5,55 \mathrm{a}$ & $2,25 \mathrm{~b}$ & $4,95 \mathrm{a}$ & $6,15 \mathrm{a}$ & $0,95 \mathrm{a}$ \\
$\mathrm{C} 4$ & $5,15 \mathrm{a}$ & $2,00 \mathrm{~b}$ & $4,90 \mathrm{a}$ & $5,65 \mathrm{a}$ & $1,15 \mathrm{a}$ \\
Valor F & $0,25 \mathrm{~ns}$ & $5,89^{*}$ & $7,35^{*}$ & $1,74 \mathrm{~ns}$ & $0,26 \mathrm{~ns}$ \\
Pr>F & 0,7782 & 0,0043 & 0,0014 & 0,1844 & 0,7682 \\
\hline
\end{tabular}

* Médias seguidas da mesma letra nas colunas não diferem entre si a $\alpha=0,05$. 


\subsection{Estudo das correlações}

A quimiometria pode ser definida como a disciplina química que utiliza métodos matemáticos e de estatística multivariada para definir ou selecionar as condições ótimas de medição e experiência, além de extrair dos dados químicos o máximo de informação (Scarmínio, 1989).

A relação entre avaliação sensorial e análise instrumental de sabor e aroma, por exemplo, é apresentada na forma de matrizes (A e B) (Aishima e Nobuhara, 1977). Os dados da matriz A, no presente trabalho, referem-se aos dois produtores, de Barretos e Limeira, representados pelas siglas C1, C2, C3 e F2, F3, F4, enquanto que os dados da matriz B provêm das análises instrumentais e sensoriais dos dois produtores. Ambas as matrizes, são conectadas usando análises multivariadas.

Os dados coletados das análises físico-químicas e sensoriais foram submetidos às análises de correlação e os resultados significativos (L>0,70), conforme Sounis (1975) são comentados a seguir:

O atributo de aparência "maduro" está correlacionado com os valores de L $(0,79), a^{*}(0,72)$ e $b^{*}(0,80)$, como era esperado, uma vez que um aumento nos valores desses parâmetros indica que a coloração do fruto está mais próxima do amarelo e do alaranjado, além de mais claro, como observado durante o amadurecimento do fruto.

O atributo "manchas" está diretamente correlacionado com os valores de L $(0,80), a^{*}(0,88)$ e $b^{*}(0,83)$ e inversamente correlacionado com os teores de clorofila $(-0,74)$, indicando que houve um aumento da pigmentação laranja e decréscimo da clorofila durante o amadurecimento dos frutos, resultando em frutos mais manchados.

Para "maduro" relacionado ao aroma observou-se uma forte correlação positiva $(0,87)$, com os valores L, a* e b* enquanto que o aroma "ácido" apresentou correlação negativa $(-0,75)$.

Como medidas objetivas, as análises de cor do flavedo, revelaram ser de grande importância na colheita no ponto ideal da laranja. 
O diâmetro dos frutos analisados correlacionou-se negativamente com os seguintes atributos de aparência "casca lisa" (-0,76) e sabor "maduro" $(-0,81)$ evidenciando que, conforme o diâmetro diminui, esses parâmetros aumentam.

A análise físico-química de pectina solúvel apresenta uma alta correlação positiva com o aroma "passado" $(0,91)$ e negativa com a textura "fibras" $(-0,77)$, indicando que, à medida que o fruto amadurece, os teores de pectina solúvel aumentam, diminuindo a firmeza do fruto e evidenciando o aroma passado. A pectina solúvel revela-se um parâmetro na caracterização do estágio de maturação do fruto.

Com relação ao teor de sólidos solúveis observam-se correlações positivas para os atributos de aparência "casca lisa" $(0,76)$ e sabor "laranja" $(0,76)$, expressando o aumento da maturação do fruto na planta.

A acidez correlaciona-se negativamente com aroma "maduro" $(-0,75)$, sabor "passado" $(-0,71)$ e textura "fibras" $(-0,76)$, pois, à medida que o fruto amadurece os teores dos ácidos em seu interior diminuem.

O parâmetro "ratio" correlaciona-se positivamente com os atributos de sabor: "maduro" $(0,71)$ e "passado" (0,93), textura: "fibras" $(0,97)$ e "suculência" $(0,92)$, mostrando que, conforme o ratio aumenta, esses atributos tornam-se fortemente perceptíveis para o provador. Esse fato indica que o ratio também é um bom parâmetro do ponto ideal de colheita da laranja.

Quanto às análises de açúcar redutor, observaram-se valores acima de $-0,74$, indicando correlação negativa com o aroma "passado", possivelmente devido à utilização desses açúcares como fonte de energia para processos metabólicos do fruto, o que estaria iniciando a sua senescência,; verificaram-se também, correlações positivas com o sabor laranja $(0,80)$, textura fibras $(0,77)$ e textura firme $(0,76)$. 
Tabela 9. Coeficientes de correlação $(>0,70)$ para os dados de análises físico-químicas e sensoriais de laranja Pêra

\begin{tabular}{|c|c|c|c|c|c|c|c|c|c|c|}
\hline & $\mathrm{L}$ & $a^{*}$ & $b^{*}$ & Clorofila & Diâmetro & $\begin{array}{l}\text { Pectina } \\
\text { solúvel }\end{array}$ & Ratio & $\begin{array}{l}\text { Açúcar } \\
\text { Redutor }\end{array}$ & SST & ATT \\
\hline $\begin{array}{l}\text { Aparência } \\
\text { maduro }\end{array}$ & 0,79 & 0,72 & 0,80 & & & & & & & \\
\hline $\begin{array}{c}\text { Manchas e } \\
\text { defeitos }\end{array}$ & 0,81 & 0,87 & 0,83 & $-0,74$ & & 0,88 & & & & \\
\hline $\begin{array}{c}\text { Cor } \\
\text { laranja }\end{array}$ & 0,86 & 0,90 & 0,86 & & & & & & & \\
\hline Casca lisa & & & & 0,91 & $-0,76$ & $-0,82$ & & & 0,76 & \\
\hline $\begin{array}{l}\text { Sabor } \\
\text { laranja }\end{array}$ & & & & $-0,84$ & & & & 0,80 & 0,76 & \\
\hline $\begin{array}{l}\text { Sabor } \\
\text { Maduro }\end{array}$ & & 0,72 & & & $-0,81$ & & 0,71 & & & \\
\hline $\begin{array}{c}\text { Sabor } \\
\text { Passado }\end{array}$ & & & & & & & 0,93 & & & $-0,71$ \\
\hline $\begin{array}{l}\text { Aroma } \\
\text { Passado }\end{array}$ & 0,72 & 0,85 & 0,73 & $-0,80$ & & 0,91 & & $-0,75$ & & \\
\hline $\begin{array}{l}\text { Aroma } \\
\text { Ácido }\end{array}$ & $-0,80$ & $-0,82$ & $-0,78$ & & & & $-0,88$ & & & 0,77 \\
\hline $\begin{array}{l}\text { Aroma } \\
\text { Maduro }\end{array}$ & 0,88 & 0,88 & 0,87 & & & & & & & $-0,75$ \\
\hline $\begin{array}{c}\text { Textura } \\
\text { Fibras }\end{array}$ & & & & & & $-0,77$ & 0,97 & 0,77 & 0,71 & $-0,76$ \\
\hline $\begin{array}{c}\text { Textura } \\
\text { Suculência }\end{array}$ & & & & & & & 0.92 & & & \\
\hline $\begin{array}{l}\text { Textura } \\
\text { Firme }\end{array}$ & & & $-0,76$ & $-0,81$ & & & & 0,76 & 0,75 & \\
\hline
\end{tabular}




\subsection{Resultados preliminares do método QFD com a identificação dos clientes}

Segundo o Ministério da Integração Nacional (2002), os principais problemas na hora da compra de frutas, legumes e verduras (FLV) são: preço $(19,1 \%$ dos entrevistados), falta do produto $(16,8 \%)$, pouca variedade $(11,7 \%)$, mancha/deformação/lesão $(11,3 \%)$, produtos passados $(9,8 \%)$ e produtos estragados $(9,0 \%)$. Na soma, $28,6 \%$ dos entrevistados indicaram falta de produtos ou pouca variedade como principais problemas.

\subsubsection{Mercado Municipal de Piracicaba (Mercadão)}

Questionário utilizado para realização da Avaliação Qualitativa no Mercado Municipal de Piracicaba:

1) Que variedades de laranja Pêra você conhece e quais as suas características? Nota-se um desconhecimento de variedades pelos consumidores de laranja Pêra que compram no mercado Municipal de Piracicaba (Figura 6); dos 35 entrevistados, 68,6\% não tinham conhecimento algum sobre qualquer variedade; $22,9 \%$ disseram que conheciam a variedade Pêra Coroa, talvez por terem tido a curiosidade de ler a plaqueta da banca que indicava o preço e "Pêra Coroa", mas não sabiam listar as características da variedade; também foram citadas por 5,7\% dos entrevistados, as variedades Lima, Rio e Natal, mas também não conheciam suas características.

Os permissionários dizem aos clientes que a Pêra Coroa é melhor como fruta de mesa por ter baixa acidez e a casca lisa e fina. Para suco, é indicada a Pêra Charmute que tem casca mais grossa e robusta, maior rendimento em caldo, mais doce com baixa acidez. 


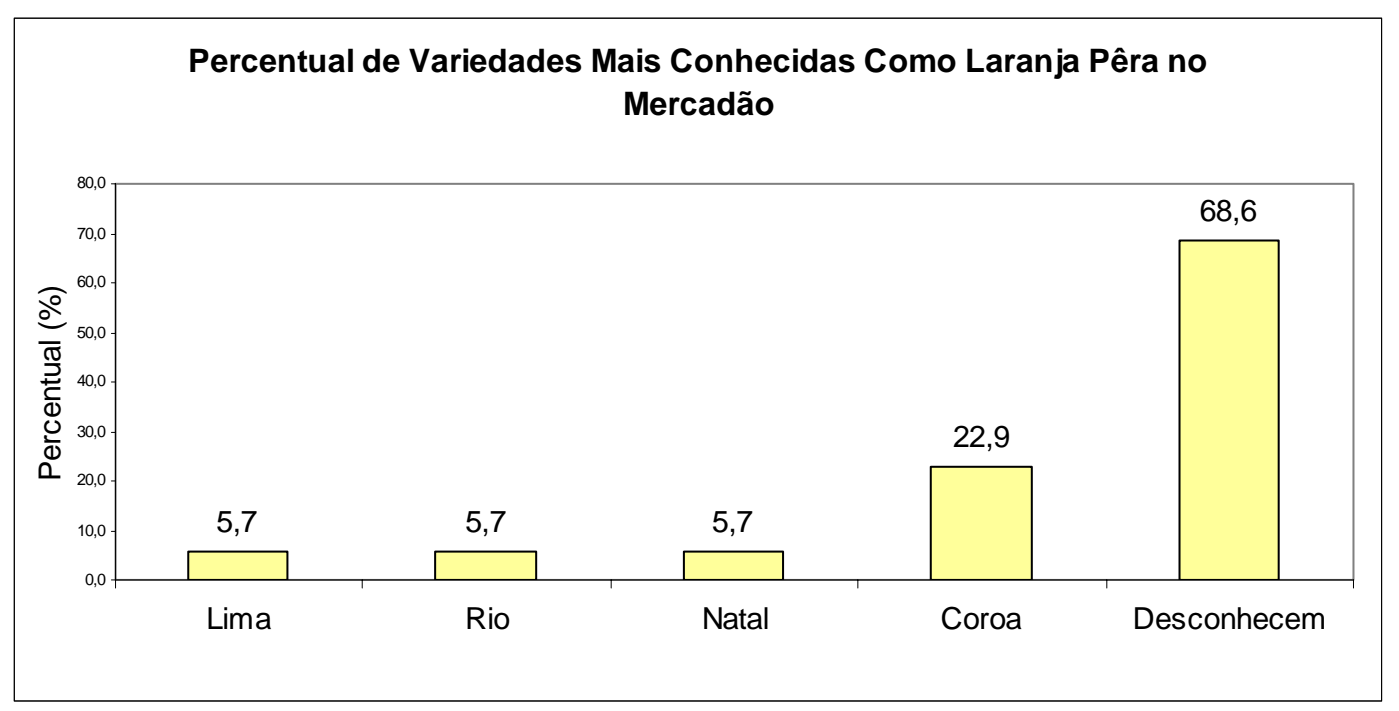

Figura 13- Percentual de variedades citadas pelos compradores de laranja Pêra no (Mercado Municipal) Mercadão

2) Qual o destino da laranja Pêra que você compra? (suco, doce, consumo in natura, etc). A maior parte dos consumidores, $74,3 \%$ dos 35 entrevistados, utilizam a laranja para suco, 62,9\% preferem "Chupar" a laranja, 40\% "Chupam" ou fazem suco e 14\% dão outros tipos de destino à fruta, como salada de frutas, bolos, etc. (Figura 14).

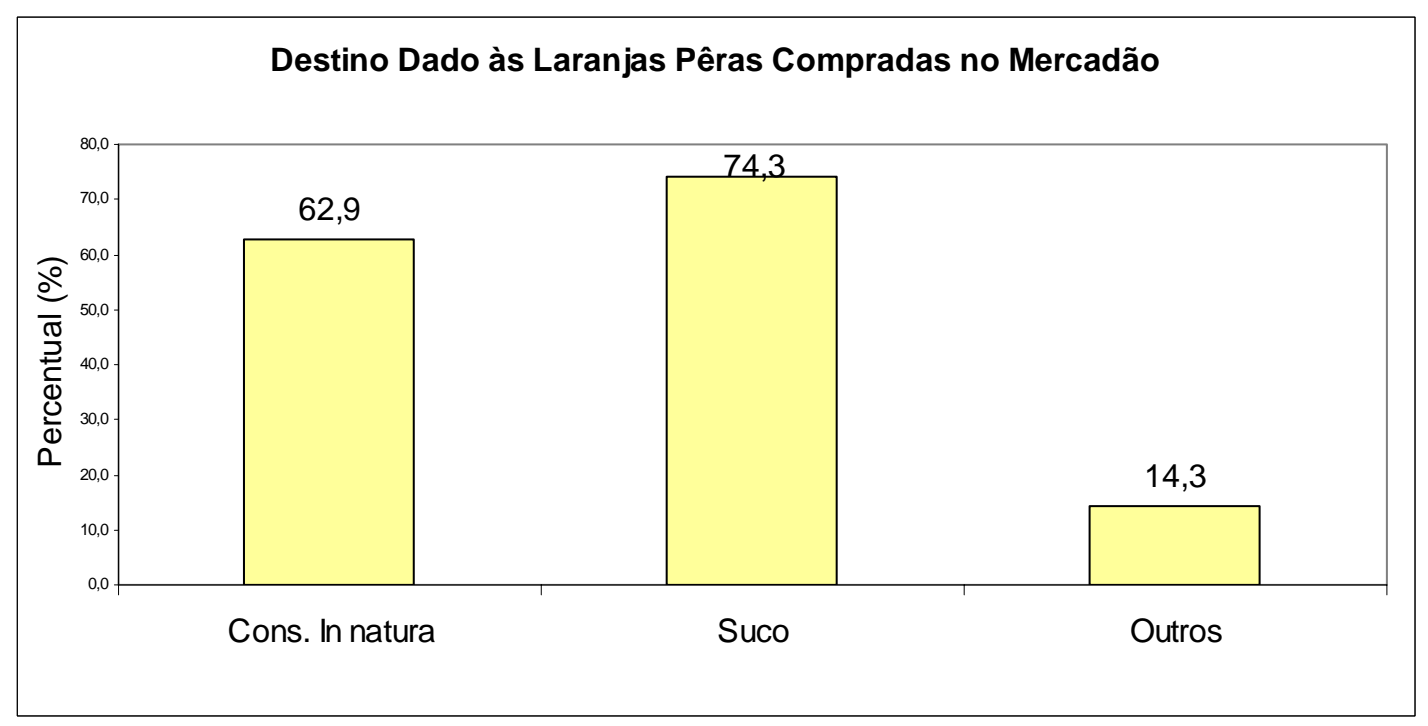

Figura 14- Destino dado à laranja Pêra comprada no Mercado Municipal de Piracicaba 
3) O que você observa no fruto na hora de comprar? Quando questionados sobre o que observavam na laranja na hora da comprar, a maioria dos entrevistados pegava a fruta na mão e listavam as características que gostariam que estivessem presentes e indicavam as que não gostavam de encontrar, às vezes mostrando a fruta que comprariam e a que recusariam. Para efeito de pesquisa foram resumidas as características e agrupadas para serem representadas no gráfico. Respostas como "durinha" e "firme" fazem parte do mesmo grupo "firmeza" na Figura 15.

A característica mais observada pelos consumidores no mercadão foi a firmeza, 48,6\% dos entrevistados apertavam a laranja para verificar sua integridade; 42,9\% observavam a coloração como indicativo do grau de maturação, justificando a iniciativa de alguns produtores que promovem a coloração da laranja aplicando etileno, técnica conhecida como desverdecimento; 20,9\% escolhiam laranjas com casca lisa, 20\% verificavam se a laranja esta passada. A ausência de defeitos e a presença de pedúnculo ("cabinho") tiveram a mesma importância na hora escolha (17,1\%) (os entrevistados consideravam manchas, podridões, doenças, ou qualquer anormalidade externa evidente, como defeitos); o tamanho foi observado por $8,6 \%$ dos consumidores; o preço foi o fator menos lembrado na hora da compra, apenas 5,7\% citaram o preço; outras características menos representativas como brilho, higiene do local, amizade com o dono da banca, etc. somaram $17,1 \%$ (Figura 15 ). 


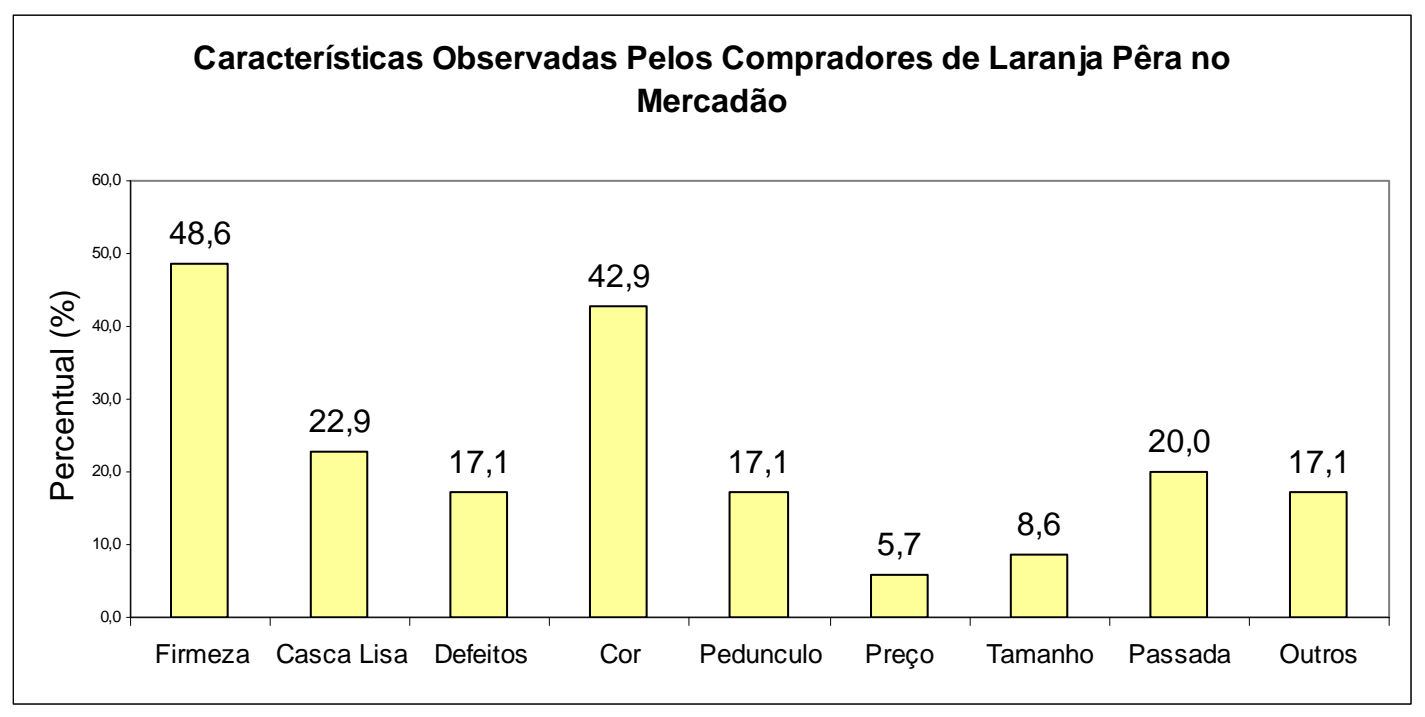

Figura 15- Características observadas pelos entrevistados no Mercado Municipal de Piracicaba

4) O que você espera da laranja in natura? A característica mais esperada pelos consumidores foi doçura, 51,4\% esperavam encontrar a laranja doce e escolhiam a laranja na banca com esta intenção. A segunda característica desejada foi suculência, provavelmente por destinarem a suco, já que 74,3\% dos entrevistados faziam suco com laranja Pêra, 40,0\% dos compradores esperavam encontrar laranja suculenta; 17,1\% dos procuravam laranja com baixa acidez; $8,6 \%$ procuravam laranja na firmeza adequada; $5,7 \%$ esperavam laranja nova sem estar passada; e 5,7\% preferiam laranja saborosa. $8,6 \%$ dos entrevistados disseram que esperavam laranjas boas, no ponto de colheita, refrigeradas, etc., estas características foram agrupadas como outros (Figura 16).

Somando as características relacionados ao sabor e textura: suculenta, doce, baixa acidez e saborosa, chegou-se ao valor de $114,2 \%$, mostrando que na maioria dos casos o consumidor está à procura de satisfação na hora de comer a fruta como sabor e textura (Obs: a soma é maior que 100\%, pelo fato de consumidores enumerarem mais de uma característica esperada). 


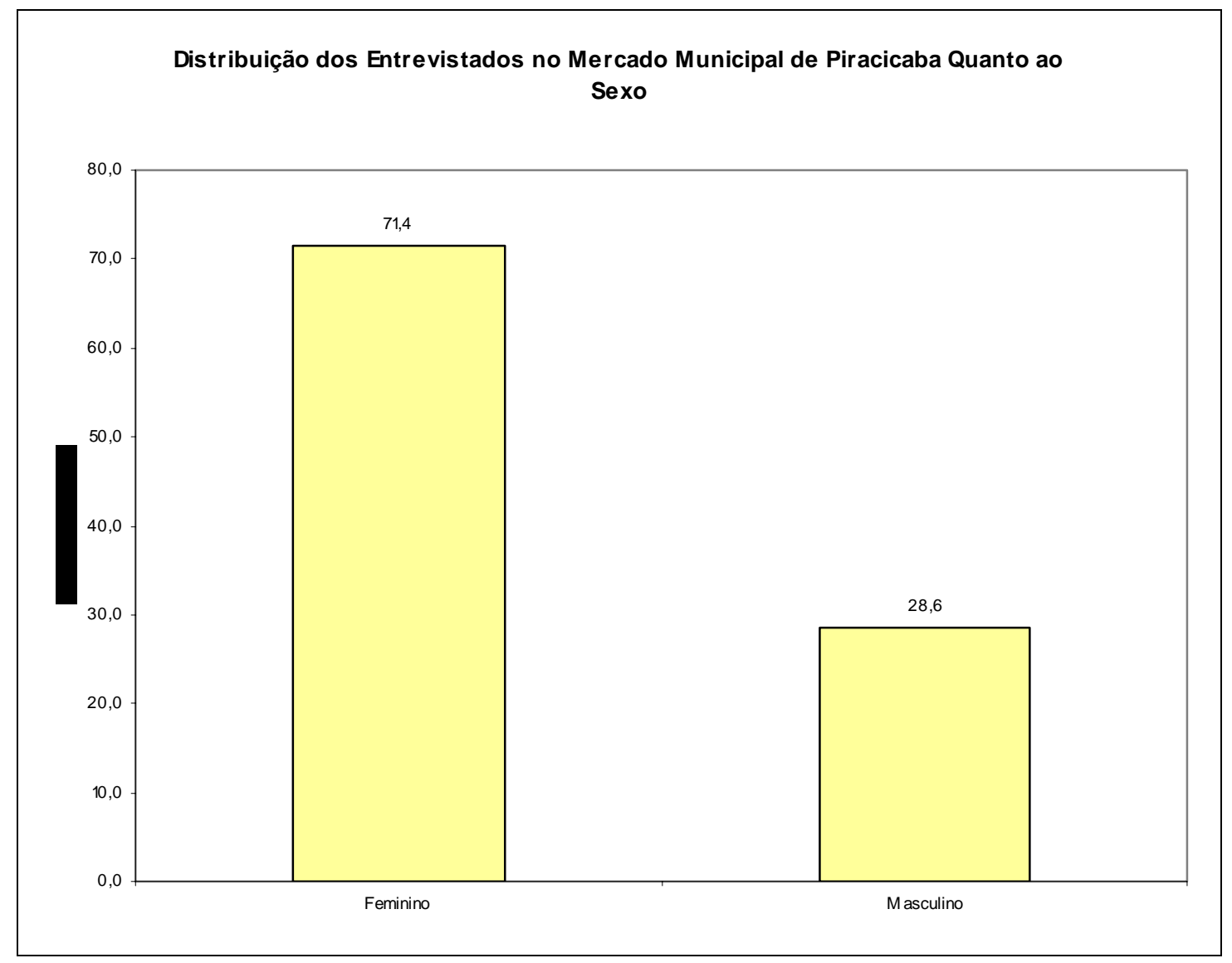

Figura 16- Características esperadas pelos entrevistados no Mercado Municipal de Piracicaba

5) Em sua opinião, qual seria a laranja Pêra ideal? A característica mais citada para laranja Pêra Ideal foi suculência (54,3\%), provavelmente pelo fato dos consumidores fazerem suco com laranja Pêra; 45,7\% dos compradores disseram que a laranja Pêra Ideal tem que ser doce; a baixa acidez foi citada por 22,9\% dos entrevistados, assim como na questão anterior, as características mais citadas estão relacionadas ao sabor e textura da fruta, nesse caso somam 125,8 \% (a soma é maior que $100 \%$, pelo fato dos consumidores enumerarem mais de uma característica); $22,9 \%$ disseram que a laranja ideal tem que ter a cor alaranjada; $20 \%$ disseram que a laranja tem que ser firme; o tamanho e a ausência de defeitos foram citados por 14,3\% dos entrevistados; a presença de pedúnculo (“cabinho") e não estar passada foram características que estiveram 
presentes em 11,4\% dos consumidores; outras características como brilho, no ponto de colheita, pronta para comer, também foram citadas como necessárias à laranja "Pêra ideal" (Figura 17).

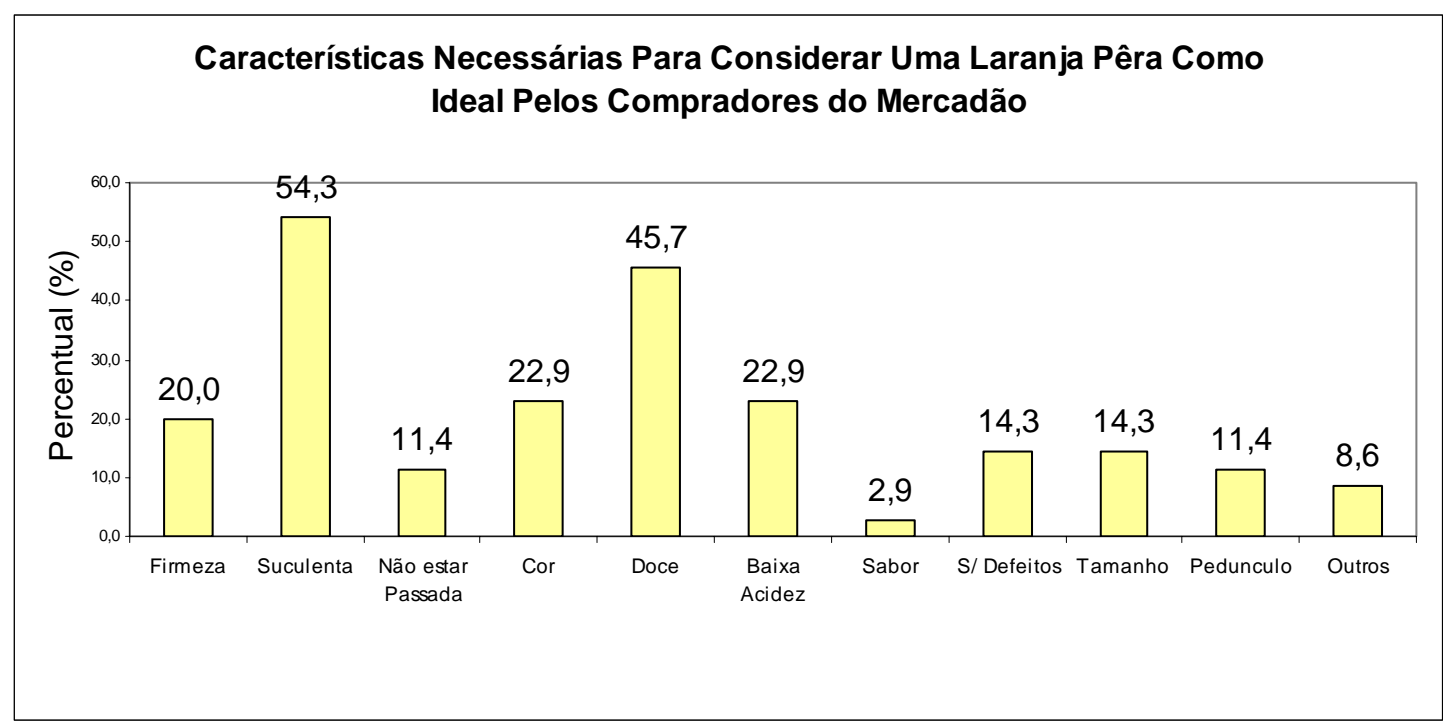

Figura 17- Características da laranja Pêra ideal citadas pelos entrevistados no Mercado Municipal de Piracicaba

6) Quais problemas você já teve com laranja? A maior parte dos entrevistados, $54,3 \%$ nunca observou problemas com laranja Pêra. O problema mais encontrado foi fruta passada, 20\%; 14,3\% disseram que encontraram laranjas muito ácidas; 11,4\% encontraram laranja sem caldo e 5,7\% reclamaram de ter comprado laranjas imaturas (Figura 18). 


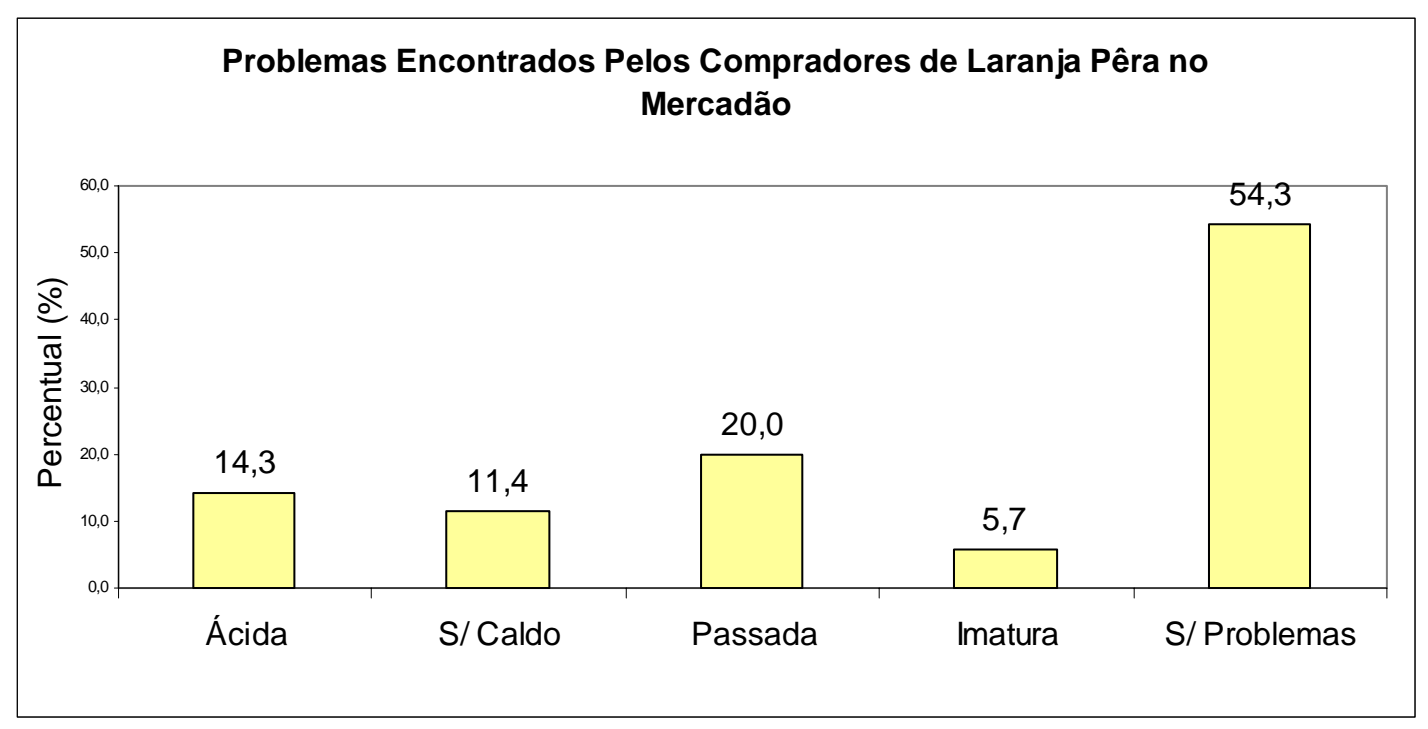

Figura 18- Problemas encontrados na laranja Pêra pelos entrevistados no Mercado Municipal de Piracicaba

7) Você pagaria a mais pela "Laranja Pêra ideal”? Concordando com a terceira questão, onde apenas 5,7\% dos consumidores observavam o preço na hora da compra, $82,9 \%$ dos entrevistados pagariam mais pela laranja que consideravam ideais e $11,4 \%$ não pagariam, 5,7\% disseram que depende da diferença do valor (Figura 19).

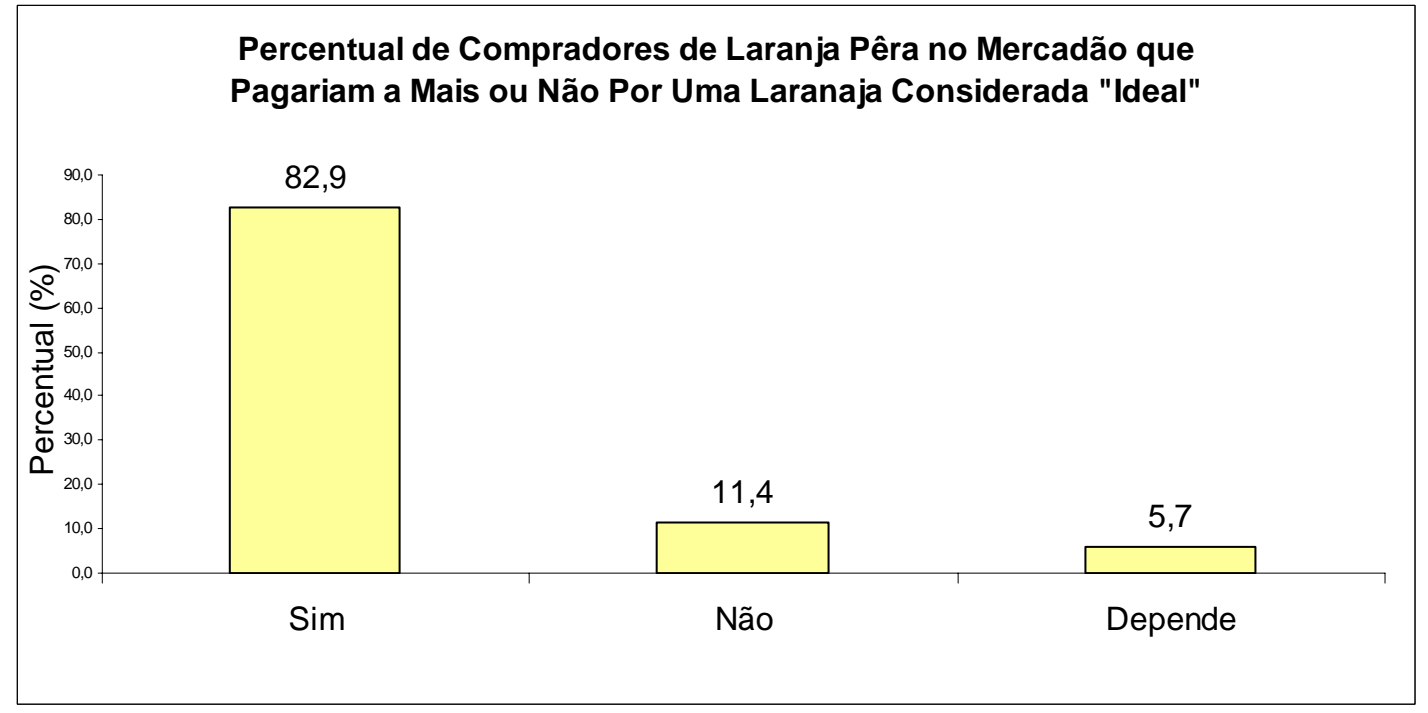

Figura 19-Percentual de entrevistados que pagariam mais pela laranja considerada ideal 
Dados Pessoais:

Foram tabulados os seguintes dados pessoais relacionados nas Figuras 13, 15, 16, 17, 18 e 19, referentes aos consumidores do Mercado Municipal de Piracicaba (Mercadão). No Supermercado Pão de Açúcar, foi permitida a aplicação do questionário, desde que não fossem feitas perguntas pessoais aos entrevistados, por isso, só foi levantada a distribuição dos consumidores do supermercado quanto ao sexo (Figura 21).

A maioria dos consumidores entrevistados no mercadão era do sexo feminino, $71,4 \%$, no supermercado, o publico feminino foi ainda maior $(77,1 \%)$. Em pesquisa publicada na Revista FrutiFatos, com dados sobre consumidores da Grande São Paulo e interior, constatou-se que $79 \%$ dos consumidores de frutas, legumes e verduras (FLV) são do sexo feminino, com pequena variação entre a capital e o interior (Ministério da Integração Nacional, 2002).

A respeito da escolaridade dos consumidores do Mercado Municipal, apenas $10 \%$ concluíram o ensino superior; $20 \%$ concluíram o ensino médio; $23,3 \%$ concluíram o ensino fundamental. A maioria, 36,7\% havia cursado a escola, mas não chegou a concluir o ensino fundamental.

Quando questionados sobre a renda familiar, notou-se um desconforto da maioria dos entrevistados, alguns preferiram não responder ao item sobre a renda, o que levava as pessoas a apresentar uma maior espontaneidade na hora de responder as perguntas. Mesmo assim, dos 35 entrevistados, 20 responderam efetivamente sua renda familiar. $40 \%$ tiveram renda compreendida entre 1 e 3 salários mínimos; $25 \%$ de 3 a 6 salários; $10 \%$ de 6 a $9 ; 10 \%$ de 9 a 12; 15\% mais que 12 salários. Fazendo um paralelo, é possível correlacionar o grau de escolaridade com a renda, a evidência de $40 \%$ terem a renda entre 1 e 3 salários pode ser explicada pelo fato de 36,7\% não terem completado o ensino fundamental. 


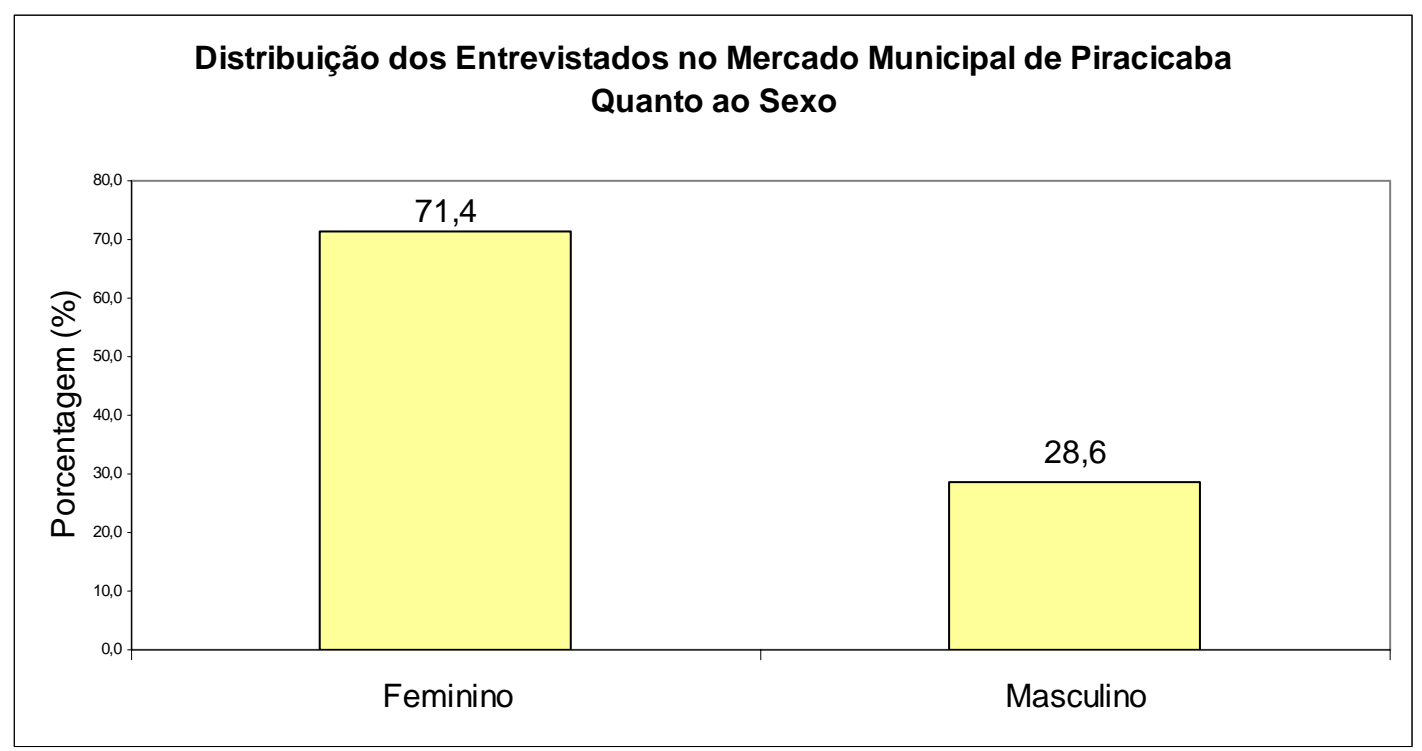

Figura 20- Distribuição quanto ao sexo dos entrevistados no Mercado Municipal de Municipal de Piracicaba

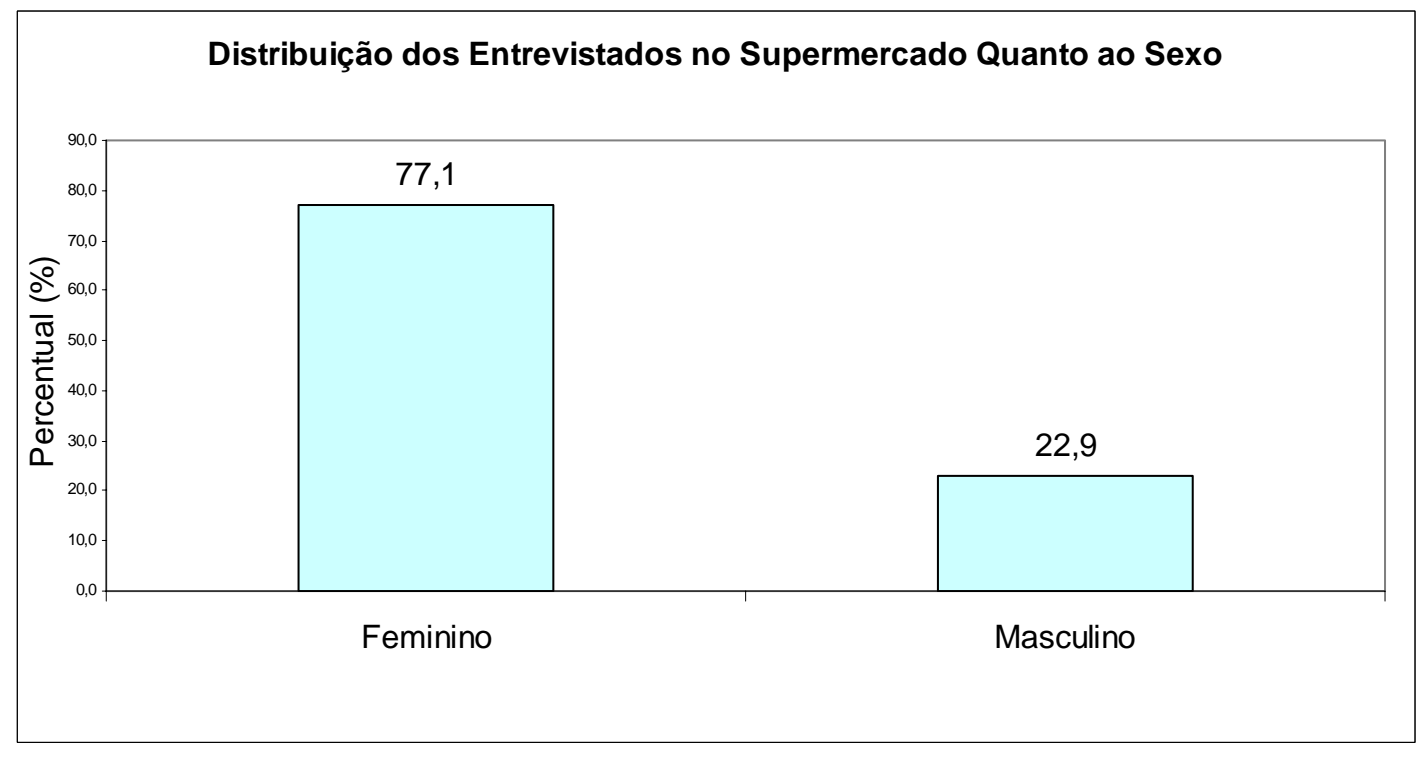

Figura 21- Distribuição quanto ao sexo dos entrevistados no Supermercado Pão de Açúcar 


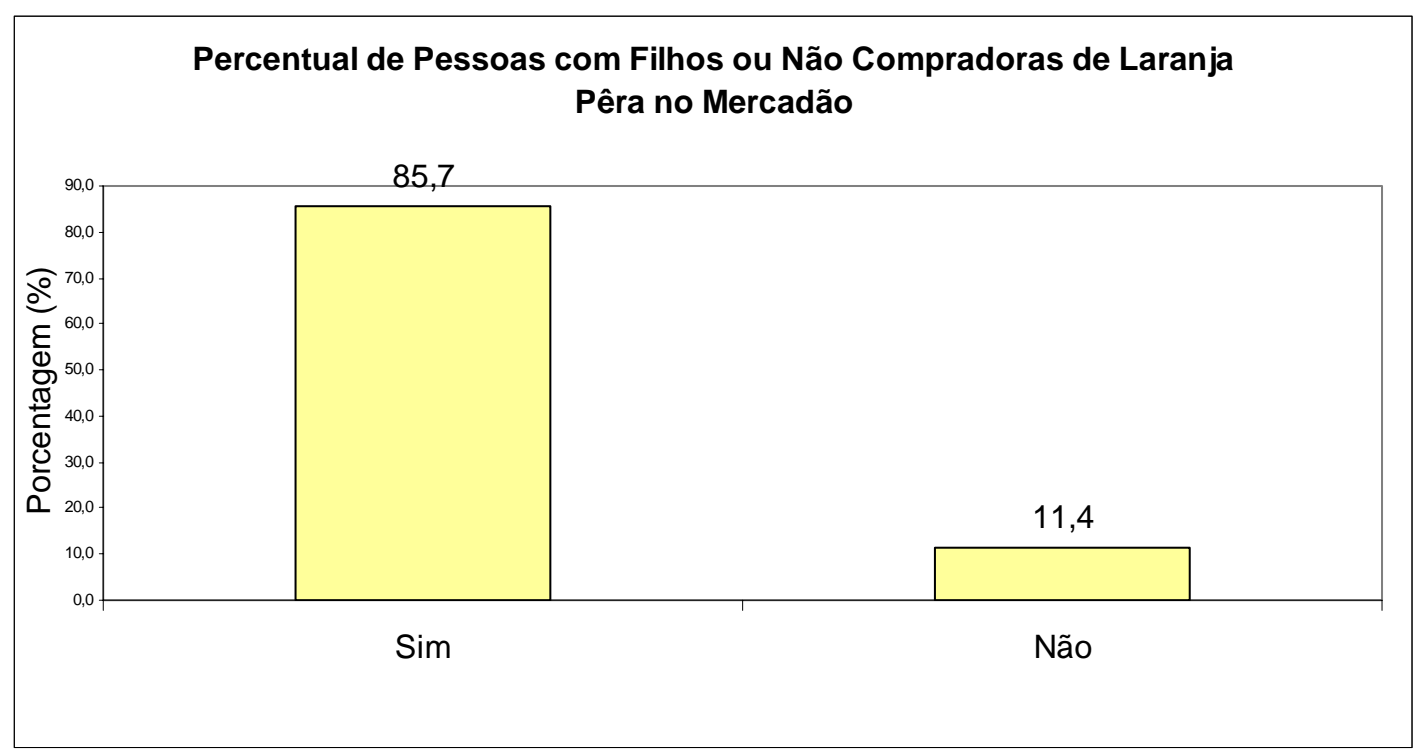

Figura 22- Distribuição dos entrevistados no Mercado Municipal de Piracicaba quanto à paternidade

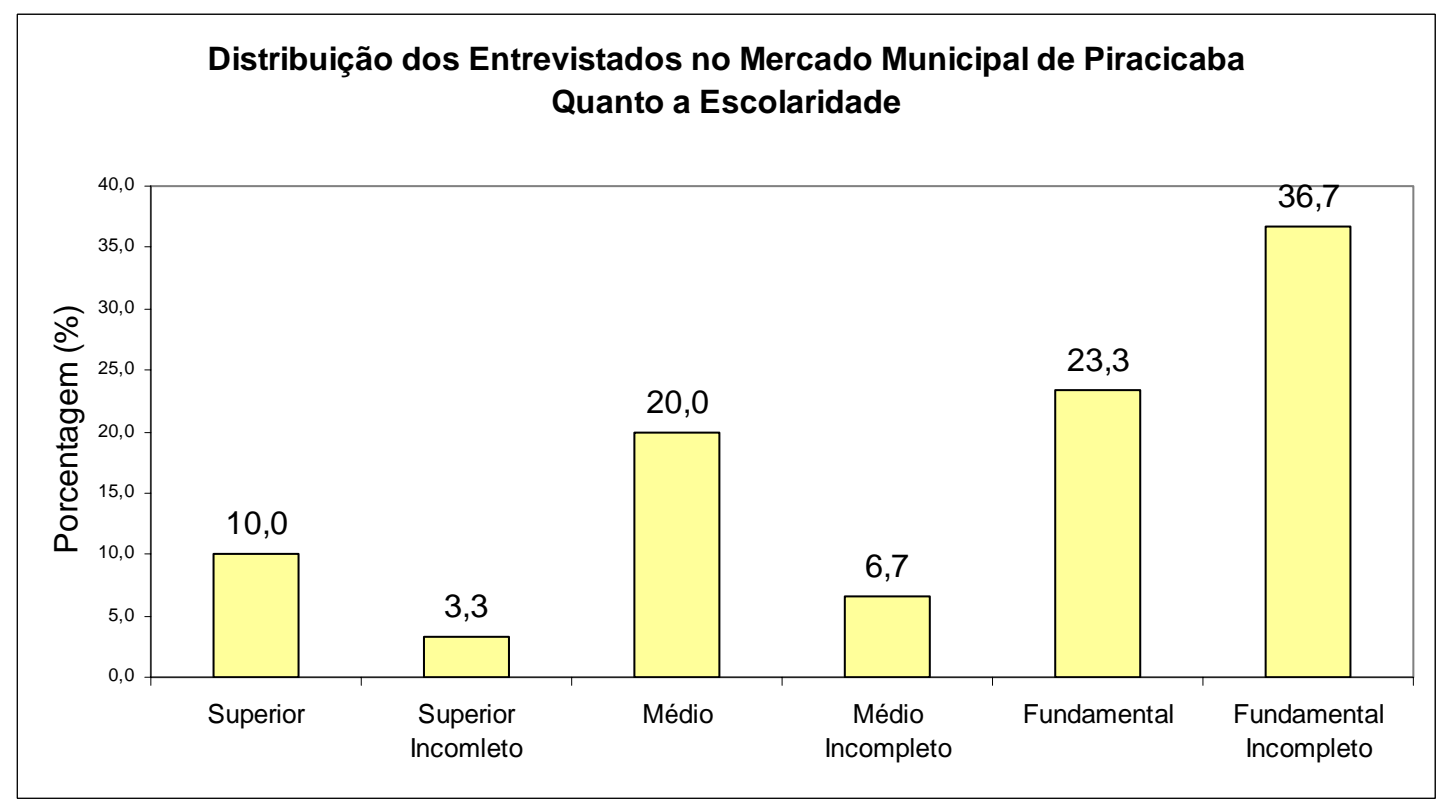

Figura 23- Distribuição dos entrevistados no Mercado Municipal de Piracicaba quanto à escolaridade 


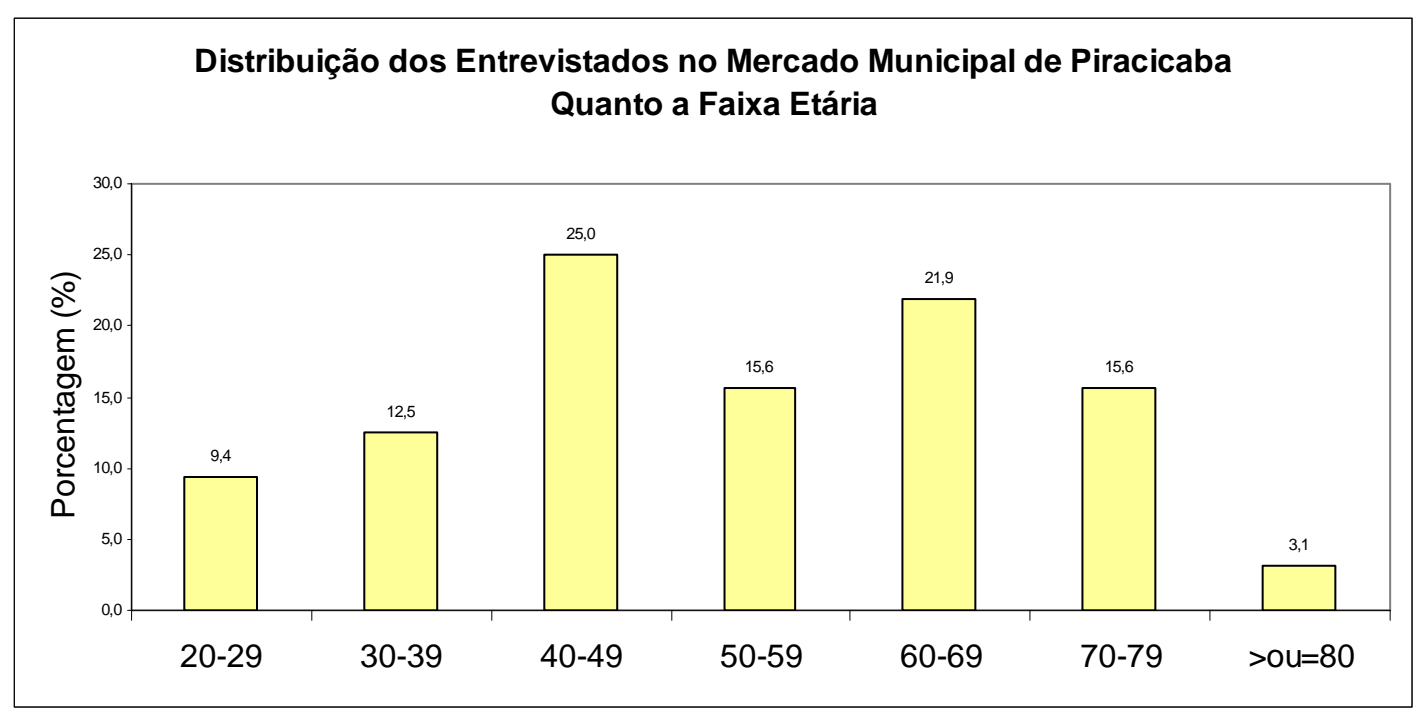

Figura 24- Distribuição dos entrevistados no Mercado Municipal de Piracicaba quanto à idade

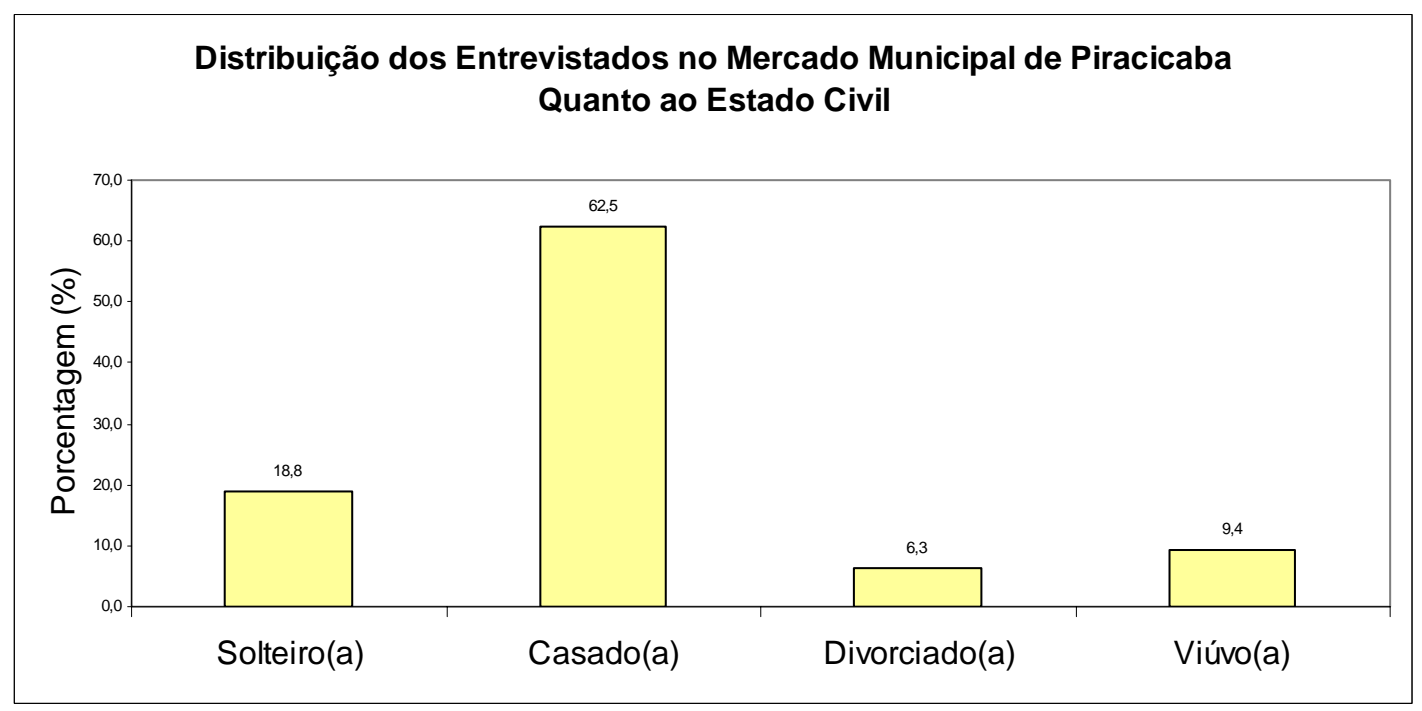

Figura 25- Distribuição dos entrevistados no Mercado Municipal de Piracicaba em relação ao estado civil 


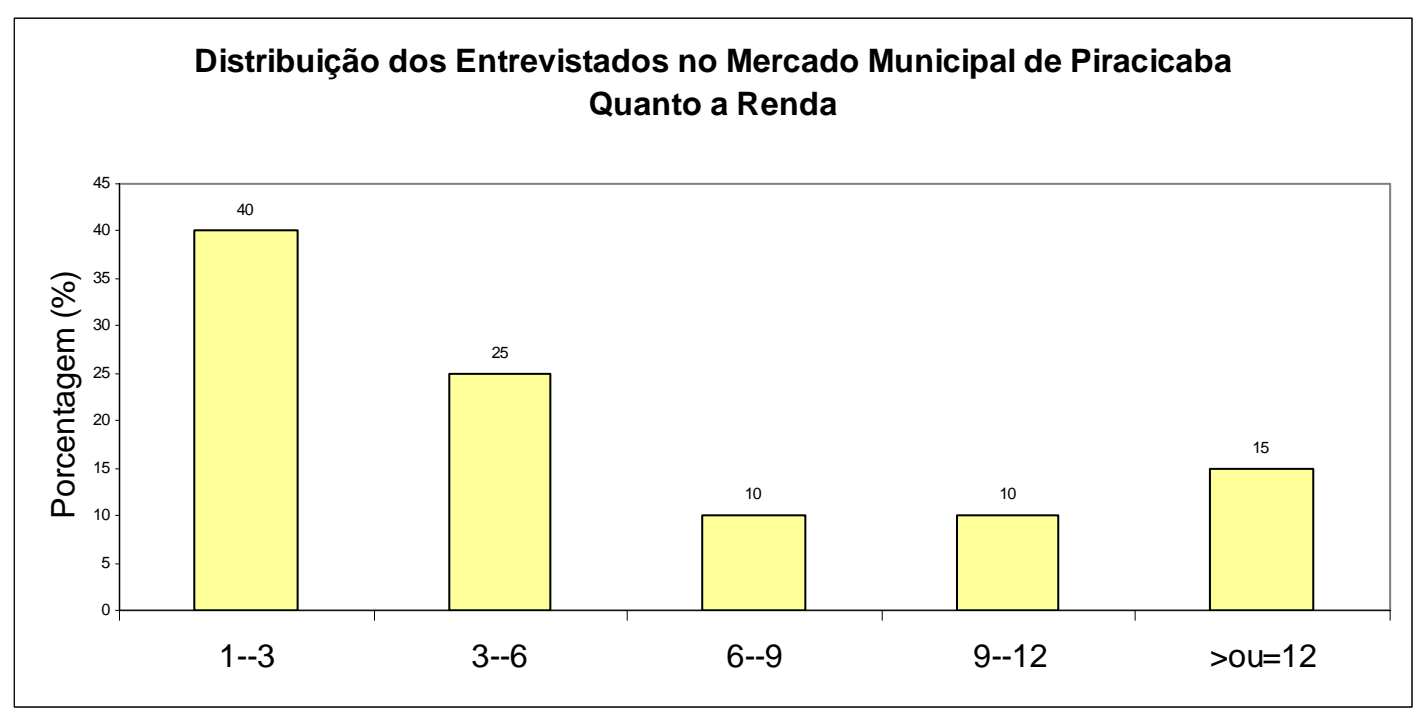

Figura 26- Distribuição em número de salários mínimos dos entrevistados no Mercado Municipal de Piracicaba

\subsubsection{Supermercado Pão de Açúcar (Centro)}

Questionário utilizado para a realização da Avaliação Qualitativa no Supermercado Pão de Açúcar (Centro).

1) Que variedades de laranja Pêra você conhece e quais as suas características?A maior parte dos consumidores entrevistados no Supermercado Pão de Açúcar não tinham conhecimento sobre variedades, 94,3 \% disseram que conheciam a laranja Pêra como sendo uma única variedade. As laranjas: Coroa, Lima, Merlim, Natal, Rio e Valência foram citadas uma vez cada, representando $2,9 \%$ dos compradores de laranja Pêra que conhecem estas variedades (Figura 27) 


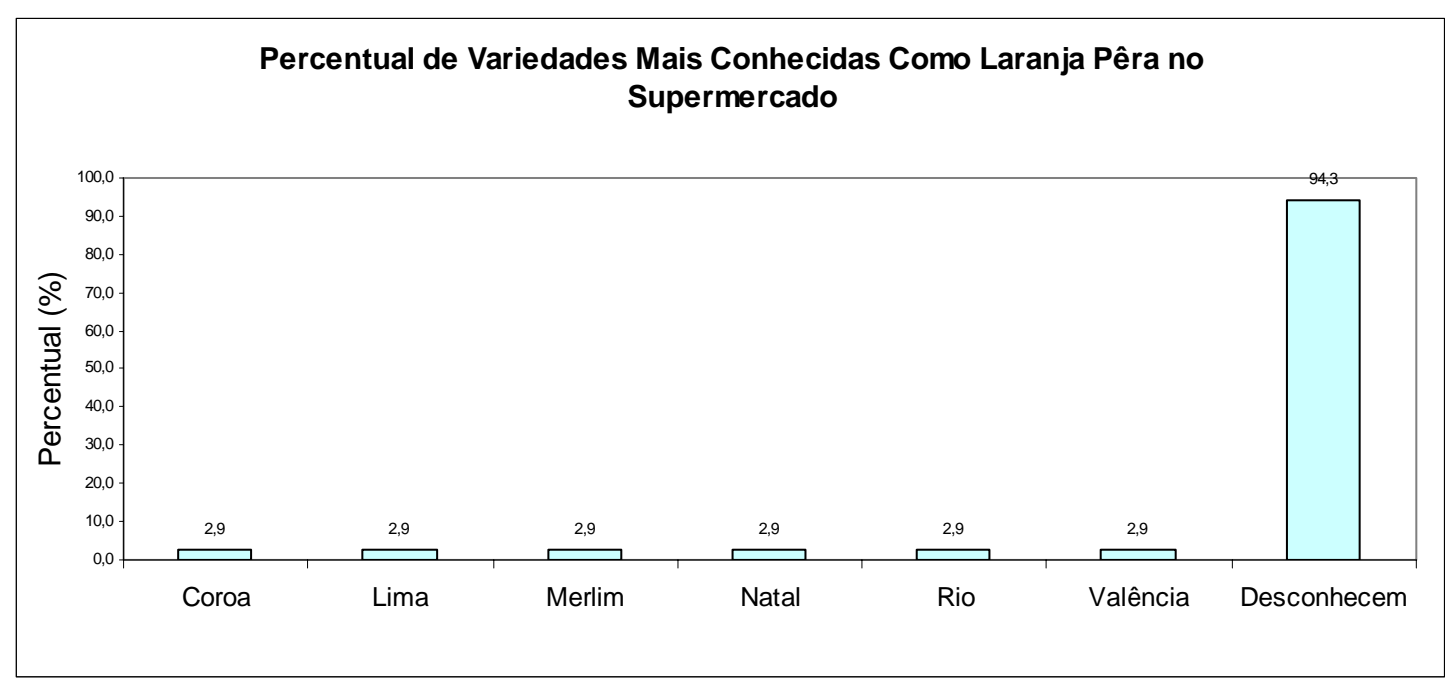

Figura 27- Percentual de variedades citadas pelos entrevistados no Supermercado Pão de Açúcar

2) Qual o destino da laranja Pêra que você compra? (suco, doce, consumo in natura, etc). A maioria dos consumidores de laranja Pêra que compram no Supermercado Pão de Açúcar faz suco com as laranjas adquiridas (88,6\%); 65,7\% preferem consumir diretamente in natura; $51,4 \%$ fazem suco e consomem a fruta fresca; 5,7\% fazem salada de frutas, bolos, etc. (Figura 28). 


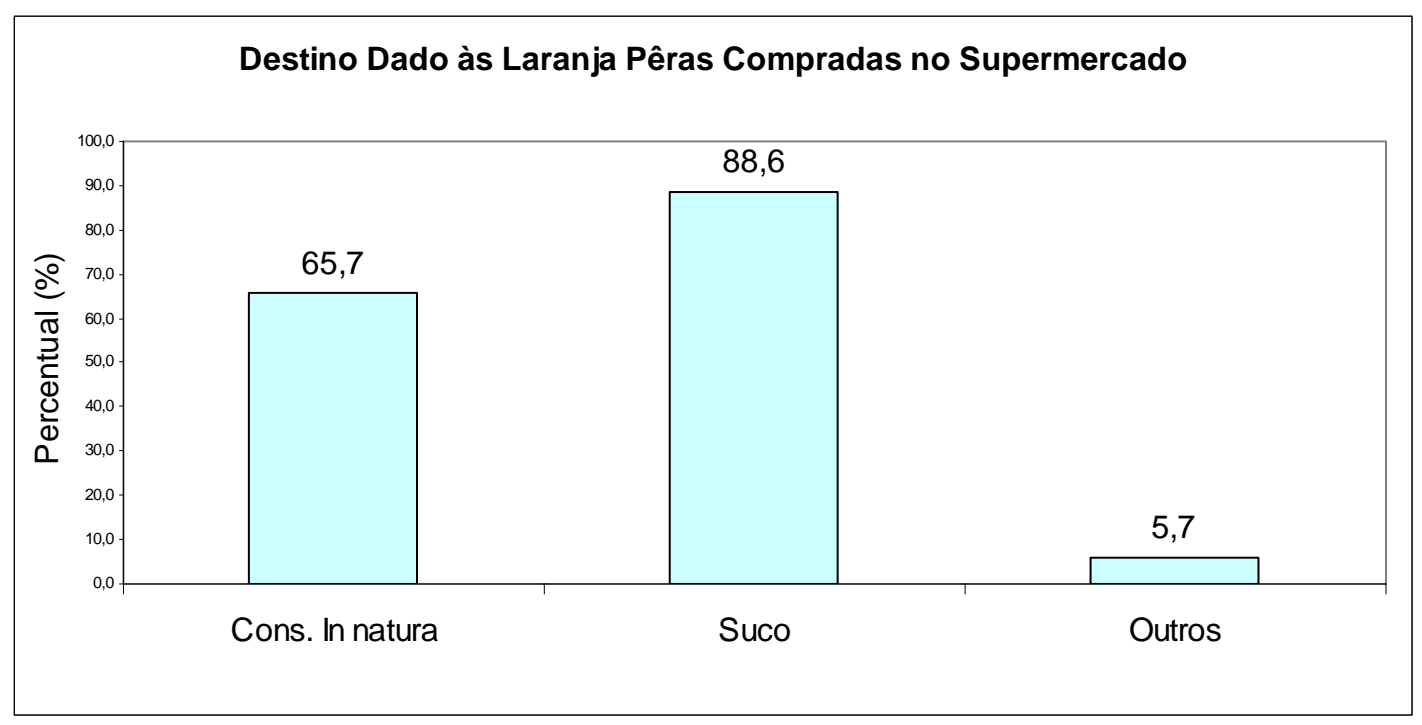

Figura 28- Destino dado à laranja Pêra comprada no Supermercado Pão de Açúcar

3) O que você observa no fruto na hora de comprar? Quando questionados sobre o que observavam na laranja na hora da comprar, alguns entrevistados pegavam a fruta na mão e listavam características que gostariam que estivessem presentes e indicavam as que não gostariam de encontrar, às vezes mostrando a fruta que comprariam e a que recusariam; para efeito de pesquisa foram resumidas as características e agrupadas (Figura 29). 


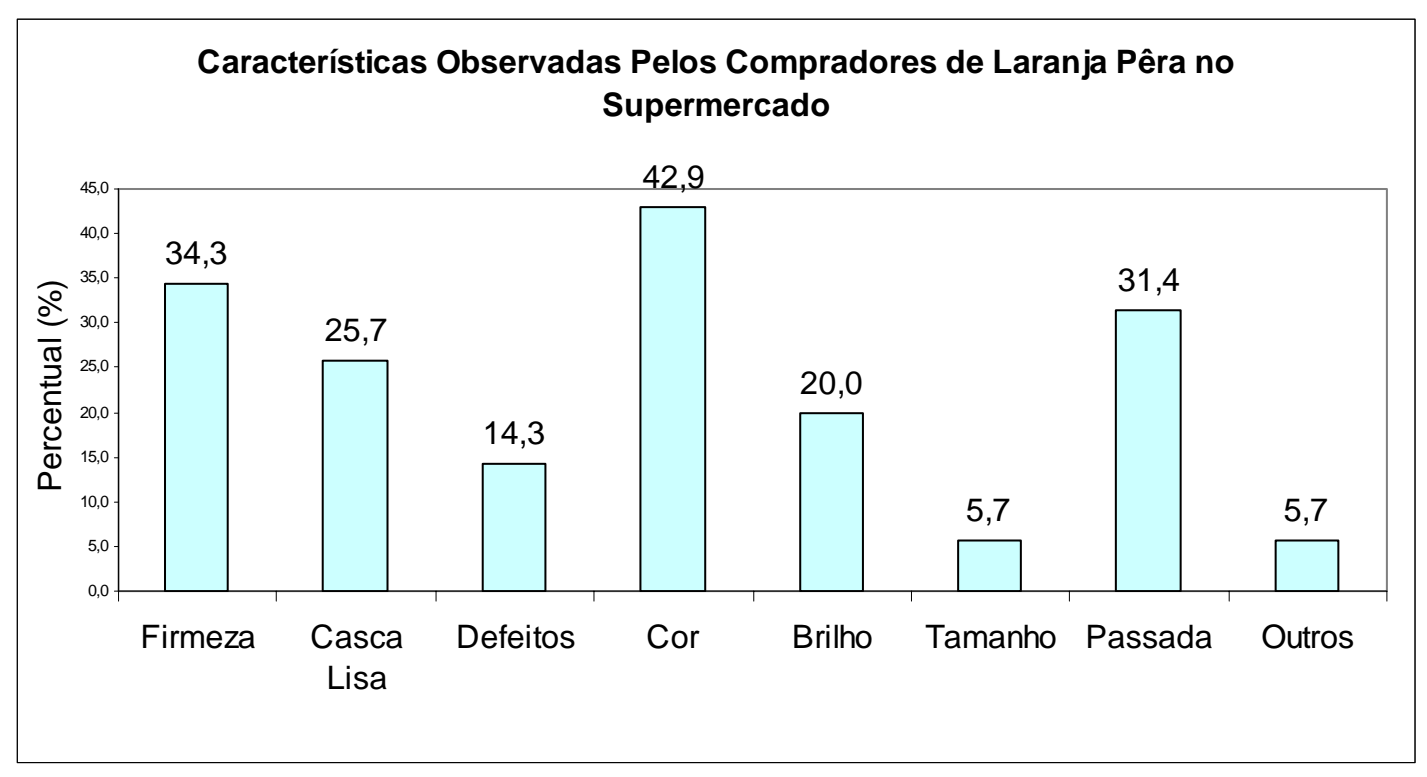

Figura 29- Características observadas pelos entrevistados no Supermercado Pão de Açúcar

Comprovando que o consumidor "compra pelos olhos", 42,9\% dos entrevistados preferem laranjas mais coloridas, alaranjadas (alguns consumidores disseram que procuram frutas amarelinhas), a coloração externa de algumas frutas indica o grau de maturação em que se encontra, essa informação provavelmente é transferida à laranja, daí se dá à preferência por frutas mais alaranjadas.

A prática de apertar a laranja para verificar seu frescor e integridade é realizada por $34,3 \%$ dos entrevistados; $31,4 \%$ observam e recusam laranjas passadas; $25,7 \%$ procuram frutas de casca lisa; $20 \%$ observam o brilho da casca; $14,3 \%$ observam se há defeitos na casca da laranja (os entrevistados consideram manchas, podridões, doenças, ou qualquer anormalidade externa evidente como defeitos); o tamanho é observado por $5,7 \%$ dos compradores de laranja; outras observações como pedúnculo e preço foram lembradas por $5,7 \%$ dos consumidores.

4) O que você espera da laranja in natura ? A característica mais esperada pelos consumidores do Supermercado Pão de Açúcar foi suculência, em reflexo do fato de que 
$88,6 \%$ dos entrevistados fazem suco com a laranja Pêra, $62,9 \%$ procuram laranja com muito caldo. Em segundo plano vem a expectativa por laranja doce, 57,1\% dos consumidores esperam encontrar laranja doce; ainda dentro do atributo sabor, 25,7\% esperam encontrar laranja com baixa acidez (não azeda). Somando os dois atributos de sabor citados: doçura e acidez chegam-se ao valor $82,8 \%$, somando ainda a atributos de textura e suculência, chega-se ao valor de 145,9\%, mostrando que os clientes estão à procura de sensações agradáveis na hora de consumir a fruta ou beber o suco (Obs. a soma é maior que $100 \%$, pelo fato dos consumidores enumerarem mais de uma característica esperada); 8,6\% dos entrevistados esperavam não encontrar laranjas passadas. A firmeza e laranja saborosa foram características citadas por 2,9\% dos entrevistados; alguns consumidores citaram atributos como "azedinha", boa, fácil de descascar, etc., agrupadas em outros na Figura 30.

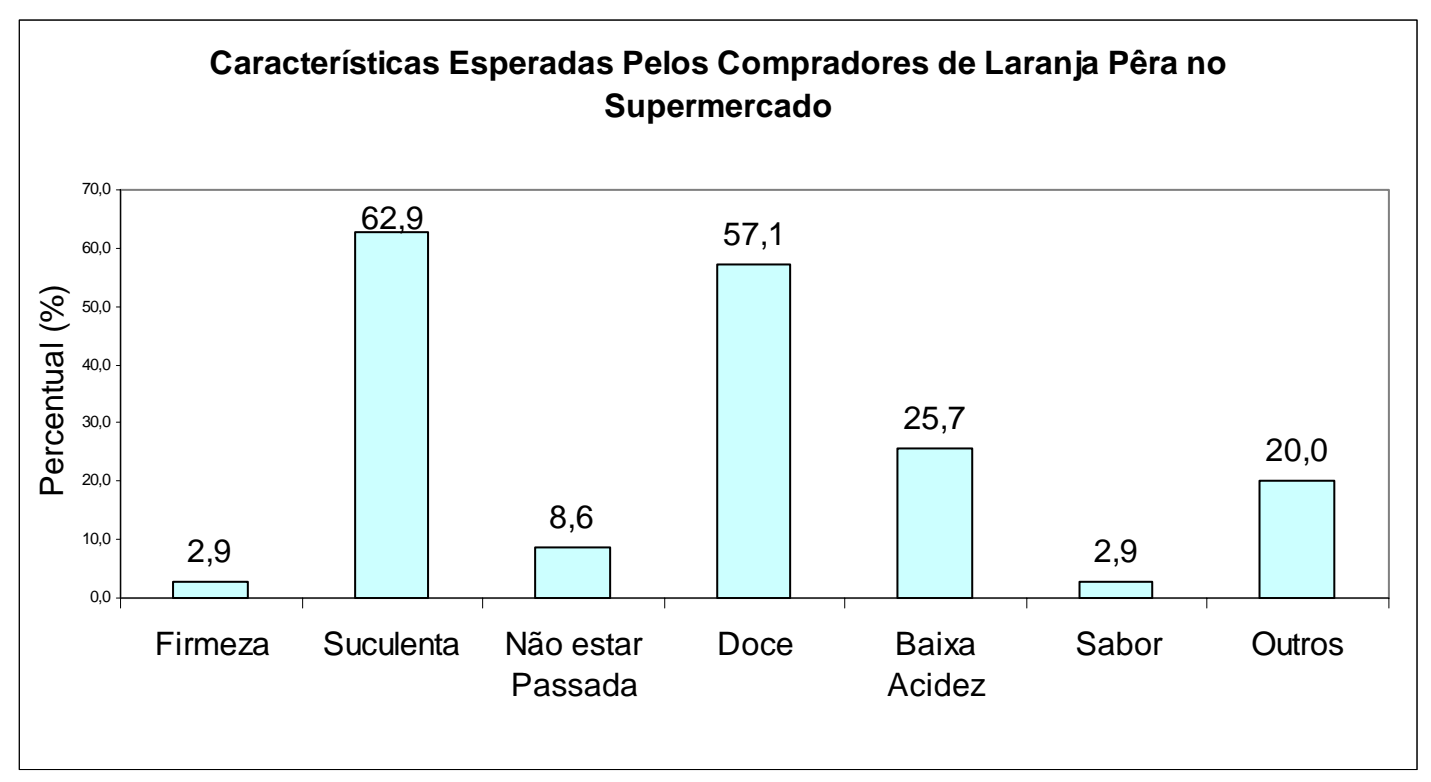

Figura 30- Características esperadas pelos entrevistados no Supermercado Pão de Açúcar

5) Em sua opinião, qual seria a laranja Pêra ideal? Quando se perguntou aos entrevistados sobre qual seria a laranja Pêra ideal, foram listadas algumas características. 
As que mais apareceram foram às relacionadas ao sabor como doçura com 57,1\% e baixa acidez (não azeda) com $28,6 \% ; 2,9 \%$ do total disseram que a laranja ideal seria "saborosa". Os atributos relacionados à textura também foram muito citados com 57,1\% dos entrevistados exigindo suculência e 17,1\% firmeza. A aparência externa também foi lembrada com $20 \%$ dos entrevistados citando a cor alaranjada, necessária à laranja ideal, $20 \%$ casca lisa, $17,1 \%$ tamanho médio, $17,1 \%$ não estar passada e $11,4 \%$ ausência de defeitos. Alguns atributos que foram pouco lembrados estão agrupados em outros na Figura 31 .

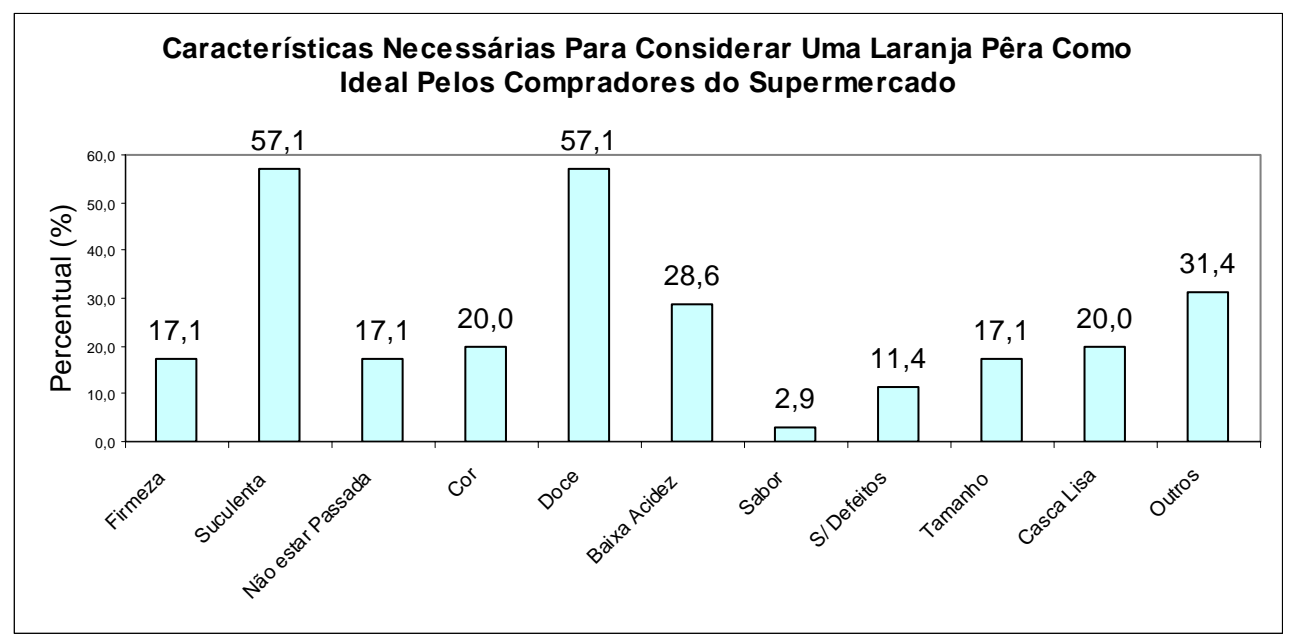

Figura 31- Características da laranja Pêra ideal, citadas pelos entrevistados no Supermercado Pão de Açúcar

6) Quais problemas você já teve com laranja? O problema mais encontrado pelos consumidores do Supermercado Pão de Açúcar foi frutas "sem" caldo; 48,6\% dos entrevistados reclamaram desse problema; $25,7 \%$ disseram que compraram laranjas passadas e $17,1 \%$ tiveram problemas com laranja muita azeda. Houve uma porcentagem elevada, mas ainda inferior nos consumidores do Mercadão, os quais nunca observaram nenhum problema, 34,3\% (Figura 32). 


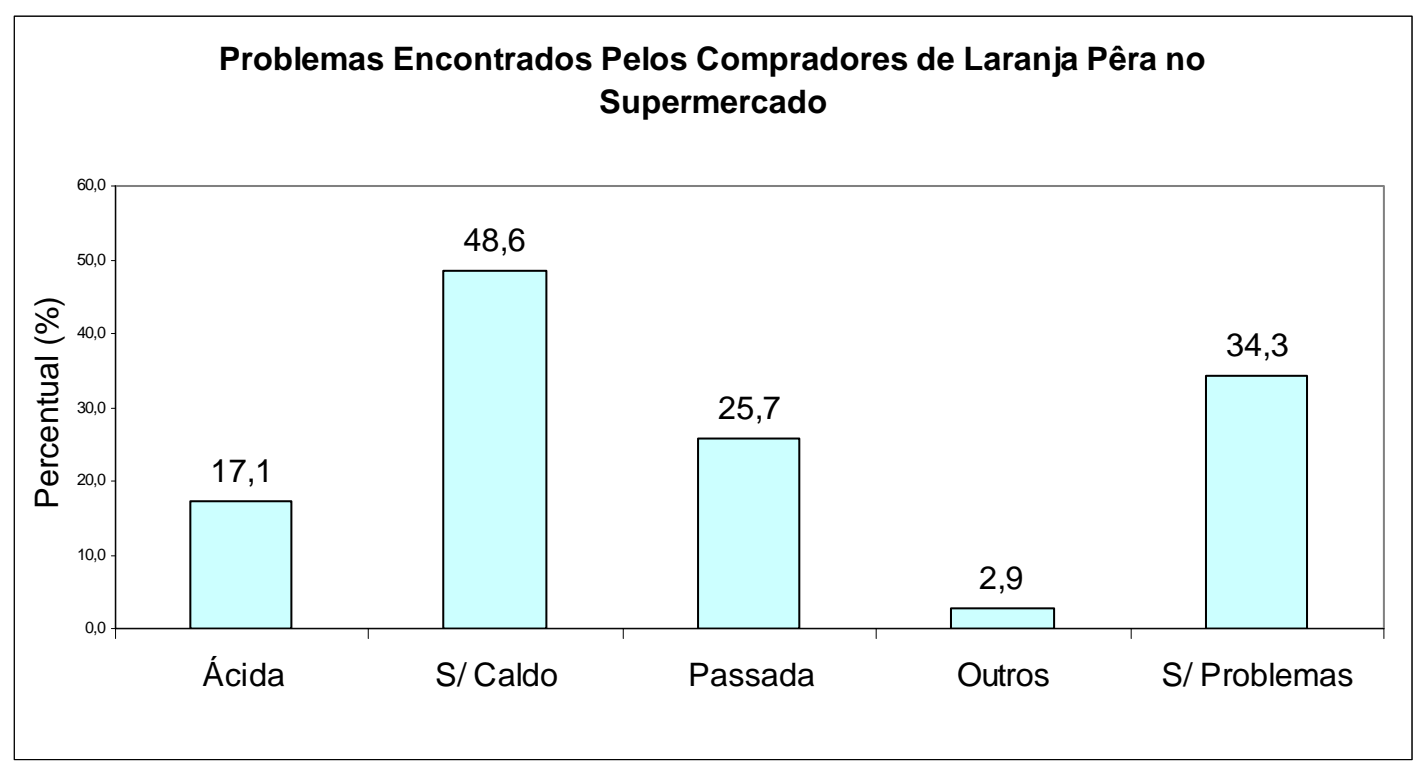

Figura 32- Problemas encontrados na laranja Pêra pelos entrevistados no Supermercado Pão de Açúcar

7) Você pagaria a mais pela "Laranja Pêra ideal”? A porcentagem de entrevistados no supermercado que aceitariam pagar mais pela laranja considerada ideal foi $85,7 \%$, valor maior que os entrevistados no Mercado Municipal, que também estavam dispostos a pagar mais pela laranja ideal $(82,9 \%) ; 11,4 \%$ dos entrevistados não pagariam mais pela laranja ideal; 2,9\% disseram que dependia da diferença de preço (Figura 33). 


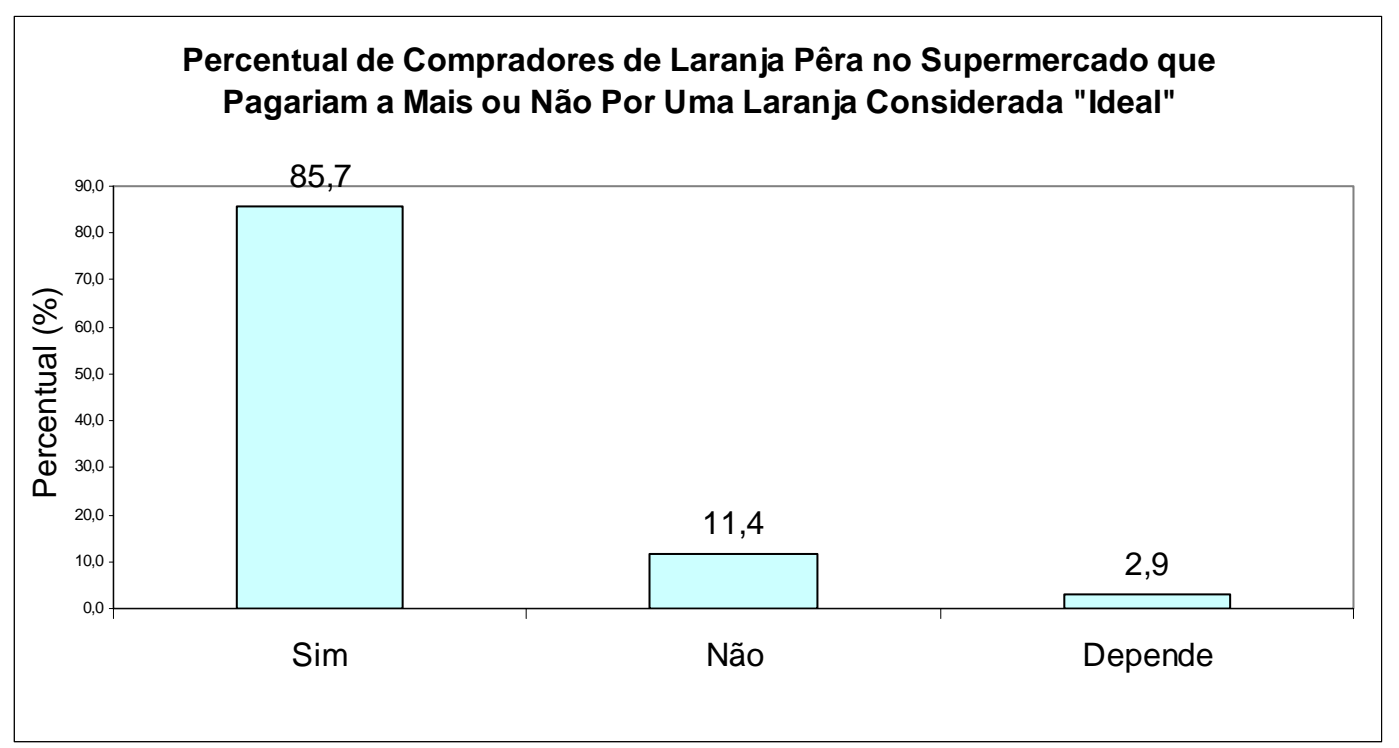

Figura 33- Percentual de compradores de laranja Pêra no Supermercado que pagariam a mais ou não por uma laranja considerada "ideal" 


\section{CONCLUSÕES}

Pelos dados obtidos em análises físico-químicas e sensorial, discutidos anteriormente, conclui-se que, para a região de Barretos, o fruto pode ser colhido a partir de C2 e para a região de Limeira, a partir de C3.

A análise da cor mostrou-se um bom parâmetro de maturação da laranja, embora seja uma análise complexa. O teor de sólidos solúveis, bem como a acidez e o ratio, os quais se correlacionam positivamente com os atributos "maduro", "passado" de sabor e “suculento" de textura, mostraram-se adequados para avaliar o ponto ideal de colheita da laranja Pêra, pois são fáceis de avaliar no campo ou no "packing-house” ou embalador.

Assim, pode-se concluir que para laranjas de mesa, a classificação por coloração do "Programa Brasileiro para a Melhoria dos Padrões Comerciais e Embalagens de Hortigranjeiros” (CEAGESP, 2000), é funcional, pois os resultados obtidos pelas análises físico-químicas e sensoriais mostram que existem diferenças entre as colorações.

As pesquisas realizadas com o consumidor da laranja Pêra, revelaram que nos dois locais comerciais da cidade de Piracicaba, a maioria era do sexo feminino, e apreciavam mais a firmeza do fruto, cor, suculência, sabor doce e baixa acidez. Todos pagariam a mais pela laranja Pêra considerada ideal. 


\section{REFERÊNCIAS BIBLIOGRÁFICAS}

ABBOTT, J.A. Quality measurement of fruits and vegetables. Postharvest Biology and Technology, n.15, p.207-225, 1999.

AISHIMA, J.A.; NOBUARA, A. Flavor evaluation by multiple regression analisys of gas chromatographic patterns en soy sauce. Food Chemistry, n.2, p.161-175, 1977.

ALMEIDA, T.C.A.; HOUGH, G.; DAMÁSIO, M.H; SILVA, M.A.A.P.da. Avanços em análise sensorial. São Paulo: Varela, 1999. p.286.

AGÊNCIA PAULISTA DE TECNOLOGIA DOS AGRONEGÓCIOS. Frutas: qualidade para conquistar novos mercados, n.7, ago. 2001.

ASSOCIAÇÃO BRASILEIRA DOS EXPORTADORES DE CÍTRICOS. www.abecitrus.com.br/informa.html. (28 ago.2003).

ASSOCIATION OF ANALYTICAL CHEMISTS. Official methods of analysis. 14.ed. Washington, 1992. 1141p.

AMERICAN SOCIETY FOR TESTING AND MATERIALS. Basic principles of sensory evaluation / Committee E-18 on evaluation of materials and products, Philadelphia : 1968. 1015 p. 
BEHRENS, J.H.; SILVA, M.A.A. Perfil sensorial de vinhos brancos varietais brasileiros através de análise descritiva quantitativa. Ciência e Tecnologia de Alimentos, v.20, n.1, p. 60-6, 2000.

BITTER, T.; MUIR, H.M. A modified uronic acid carbazole reaction. Analytical Chemistry, v.34, p. 330-334. 1962.

BLEINROTH, E.W.; SIGRIST, J.M.M.; ARDITO, E.F.G.; CASTRO, J.V.; SPAGNOL, W.A.; NEVES FILHO, L.C. Tecnologia pós-colheita de frutas tropicais. 2.ed. Campinas: ITAL, 1992. 203p. (Manual Técnico, 9).

BRASIL. MINISTÉRIO DA AGRICULTURA E DO ABASTECIMENTO. Secretaria de Política Agrícola. Comércio Exterior Brasileiro. Estatísticas Agrícolas. http:.//www.ministériodaagricultura.gov.br (1 out. 2000).

BRASIL. MINISTÉRIO DA AGRICULTURA E DO ABASTECIMENTO. Secretaria de Política Agrícola. Comércio Exterior Brasileiro. Estatísticas Agrícolas. http://www.ministériodaagricultura.gov.br (24 out.2001).

BRASIL MINISTÉRIO DA INTEGRAÇÃO NACIONAL. Secretaria de Infra-Estrutura Hídrica. Departamento de Desenvolvimento Hidroagrícola. Frutifatos: informação para a fruticultura irrigada. Brasília: 2002. v.2, n.2, 64p.

CALORE, L.; VIEITES, R.L. Conservação de pêssegos "Biuti” por irradiação. Ciência e Tecnologia de Alimentos, v. 23, p.53-57. 2003.

CENTRO DE ESTUDOS AVANÇADOS EM ECONOMIA APLICADA http://cepea.esalq.usp.br*cepea@esalq.usp.br (10 out.2004). 
CHENG, L.C.; SCAPIN, C.A.; OLIVEIRA, C.A.de; KRAFETUSKI, E; DRUMOND, F.B.; BOAN, F.S; PRATES, L.R.; VILELA, R.M. QFD: planejamento da qualidade. Belo Horizonte: Fundação Christiano Ottoni, 1995. 261p.

CHITARRA, M.I.F; CHITARRA, A.B. Pós-colheita de frutos e hortaliças: fisiologia e manuseio. Lavras: ESAL/ FAEPE, 1990. 320p.

CIVILLE, G.V.; SZCZESNIAK, A.S. Guidelines to training a texture profile panel. Journal of Texture, v.4, p.204-223, 1973.

CLYSDESDALE, F.M. Colorimetric methodology and applications. Critical Review of Food and Nutrition, v.10, p.243-301, 1978.

COCHRAN, W.G.; COX, G.M. Experimental designs, 2.ed. New York: John Wiley, 1957.

COMPANHIA DE ENTREPOSTOS E ARMAZÉNS GERAIS DO ESTADO DE SÃO PAULO. Classificação da laranja (Citrus sinensis, L. Osbeck). Programa brasileiro para a melhoria dos padrões comerciais e de embalagem de hortigranjeiros. São Paulo, 2000.

FERREIRA, V.L.P.; ALMEIDA, T.C.A.de; PETTINELLI, M.L.C.de; SILVA, M.A.A.P.da; CHAVES, J.B.P.; BARBOSA, E.M.de M. Análise sensorial: testes discriminativos e afetivos. Campinas: SBCTA, 2000. 127p. (Série Qualidade).

FOOD AND NUTRITION INFORMATION CENTER. U.S. Department of Agriculture (USDA). www.nal.usda.gov/fnic/_ (15 jul.2003). 
FRANCIS, F.J. Color quality evaluation of horticultural crops. HortScience, n.15, p.1415.1980 .

FUNDO DE DEFESA DA CITRICULTURA. www.fundecitrus.com.br/ informativo/nota_mapcadeia0404.html.(19 abr. 2004).

GERMANO, R.M.de A. Disponibilidade de ferro na presença de Beta caroteno e o efeito dos interferentes em combinações de alimentos. Dissertação (Mestrado). Escola Superior de Agricultura Luiz de Queiroz, Universidade de São Paulo. 2002. 95p.

GIACOMINO, A. Comunicação pessoal, 2002.

GLOBORURAL.globo.com/edic/197/giro.htm. (18 jun. 2004).

GOMES, M.S. Conservação pós-colheita: frutas e hortaliças. Brasília: Embrapa SPI, 1996, 134p.

HENRY, L.J.; EYNON, L. Determination of reducing sugars: solution with methylene blue indicator. London: N. Rodger, 1934. 78p.

HOFFMAN, R.; ENGLER, J.J.C. Administração da empresa agrícola. 2ed. São Paulo: Pioneira, 1978. 325p.

HUNTER, R.S.; HAROLD, R.W. The measurement of appearance. New York: Wiley-Interscience, 1987.

JACOBS, M.B. The chemical analysis of food products. New York:Van No strand, 1956. 979 p. 
KIMBALL, D. Citrus processing quality control and technology. New York : Van Nostrand Reinhold, 1991.473p.

KLUGE, R. A; NACHTIGAL, J.C.; FACHINELLO, J.C.; BILHALVA, A.B. Fisiologia e manejo pós-colheita de frutas de clima temperado. Campinas 2.ed. Livraria e Editora Rural, 2002. 214p.

LEME JÚNIOR, J.; MALAVOLTA, E. Determinação fotométrica de ácido ascórbico. Anais da Escola Superior de Agricultura Luiz de Queiroz, v.7, p.115-129, 1950.

LICHTENTHALER, H.K. Chlorophylls and carotenoids: pigments of photosynthetic biomembranes. Methods in Enzymology, v.148, n.22, p. 346- 382, 1987.

MAcCREADY, PM.; McCOMB, E.A. Extraction and determination of total pectic material. Analytical Chemistry, v.24, n.12, p.1586-1588, Dec. 1952.

MANICA, I. Curso de citricultura. Viçosa: UFMG, 1966. 90p.

MATTAR, F.N. Pesquisa de marketing: metodologia, planejamento. São Paulo: Atlas, 1999. v.1,. 337p.

MATOO, A.K.; MURATA, T.; PANTASTICO, E.B.; CHACHIN, K; OGATA, K; PHAN, C.T. Chemical changes during ripening and senescence. In: PANTASTICO, E B. Postharvest physiology handling and utilization of tropical and subtropical fruits and vegetables. Westport: The AVI Publishing, 1975.p.103-127. 
MEILGAARD, M.; CIVILLE, V.; CARR, B.T. Sensory evaluation techniques. Boca Raton: CRC Press, 1991. 354p.

MINOLTA. Precise color communication. Ramsey: Minolta, 1994.

MOSKOWITZ, H.R. Product testing and sensory evaluation of foods: marketing and R \& D Approaches. Press.1983. 605p.

OLIVA, B.P. Influência das variedades cítricas (Citrus sinensis L. Osbeck) Natal, PêraRio, e Valência na qualidade do suco de laranja pasteurizado. Campinas, 2002. 162p. Tese (Doutorado). Faculdade de Engenharia de Alimentos. Universidade de Campinas.

ORIGEM da laranja Americana é brasileira. O Estado de São Paulo, São Paulo, 22 ago. 2004.

PC-ORD for Windows 95, 98, 00, ME, NT, and XP Multivariate analysis of ecological data version 4. http://www.ptinet.net/ mjm/pcordwin.htm(22 set. 2004).

PROCTOR, F.J.; CAYGILL, J.C. Ethylene in commercial postharvest handling of tropical fruit. In: EASTER SCHOOL, 39, Proceedings. London: University of Nottingham, 1985. p.317-322.

RANZANI, R.T.C.; PRADO FILHO, L.G. Substâncias fenólicas em alimentos. Piracicaba: ESALQ. Depto. Ciência e Tecnologia Agroindustrial, 1991.91p. 
REIS, J.M.R.; LIMA, C.L.; VILAS BOAS, E.V.de B.; CHITARRA, A.B. Relação entre o grau de coloração da casca e algumas características de qualidade de tangerina “Ponkan”. Ciência e Agrotecnologia. Lavras, v.24 p.182-186, dez., 2000. Edição Especial.

RUSSO JÚNIOR, M. Aplicações da energia solar. São Paulo: Cesp. 1980.

SACKS, E.J.; SHAW, DV. Optimum allocation of objective color measurements for evaluating rash strawberries. Journal of American Society for Horticultural Science, v.119, n.2, p.330-334, 1994.

SARTORI, I.A.; KOLLER, O.C.; SCHWARZ, S.F.; BENDER, R.J., SCHÄFER, G. Maturação de frutos de seis cultivares de laranjas-doces na depressão central do rio grande do sul. Revista. Brasileira de Fruticultura, v.24, n.2, p. 364-369, ago. 2002.

SCARMÍNIO, I.S. Desenvolvimento de um sistema quimiométrico para microcomputadores e algumas aplicações. Tese (Doutorado). Instituto de Química, Universidade de Campinas. Campinas, 1989. 1v.

SIMÃO, S. Manual de fruticultura. Piracicaba: Agronômica Ceres, 1971. 529p.

SINCLAIR, W.B. The biochemistry and physiology of lemon and other citrus fruits. Oakland: 1984, 946 p.

SOUCI, S.W.; FACHMANN, W.; KRAUT, H. Food composition and nutrition tables. Zaragoza : Acribia , 1999. 430p. 
SOUNIS, E. Bioestatística: princípios fundamentais, metodologia estatística, aplicação às ciências biológicas. 2ed. São Paulo: McGraw-Hill, 1975.

SOUZA, A.C. Frutas cítricas: singularidades do mercado. Preços Agrícolas, mai-jul., p.8-10, 2001.

SPOTO, M.H.F. Técnicas quimiométricas na avaliação do sabor e aroma de suco de laranja irradiado. Piracicaba, 1994.145p. Tese (Doutorado). Centro de Energia Nuclear na Agricultura, Universidade de São Paulo.

STONE, H.J.; SIDEL, S.; OLIVIER, A.; WOOLSEY, R.C.; Singleton. Sensory evaluation by quantitative descriptive analysis. Food Technology, v.28, n.11, p.24- 34, 1974.

STONE, H.J. Quantitative descriptive analysis (QDA). In: ASTM. Manual on descriptive analysis testing. West Conshohocken: American Society for Testing and Materials. 1983. (ASTM Manual).

SWAIN, T.; HILLIS, W.G. The phenolic constituents of Prunus domestica . Journal of the Science of Food and Agriculture, v.10, p.63-69, 1959.

TODA FRUTA.Variedades de laranja para indústria. http://www.todafruta.com.br/todafruta/mostra_conteudo.asp?conteudo=1876. 22 ago. 2004.

VIÉGAS, F.C.P. A Citricultura brasileira, 2.ed. Campinas, Cargill, 1991. 
VOLPE, A.C.; SHÖFFELE, R.; BARBOSA, J.C. Influência da soma térmica e da chuva durante o desenvolvimento de laranjas "Valência" e "Natal" na relação entre sólidos solúveis e acidez e no índice tecnológico do suco. Revista Brasileira de Fruticultura. v.24, p.436-441, ago. 2002.

WALD, A. Sequential analysis. New York; London: J. Wiley \& Sons: Chapman \& Hall, 1947. p.212.

ZIEGLER, L.W.; WOLFE, H.S. Citrus growing in Florida. Gainesville: The University Press of Florida, 1975. 246p. 